\title{
Ретроспективный анализ \\ состояния популяций крапчатого суслика \\ (Spermophilus suslicus Güldenstädt, 1770) \\ в Центральном Черноземье с сопредельными территориями \\ и возможные пути сохранения вида
}

\author{
С.Ф. Сапельников ${ }^{1}$, И.И. Сапельникова ${ }^{2}$ \\ 1 Ломовской природный ландшафтный парк, \\ Россия, 397570, Воронежская обл., Воробьевский р-н, с. Воробьевка, пл. Свободы, 2 \\ ${ }^{2}$ Воронежский государственный природный биосферный заповедник им. В.М. Пескова, \\ Россия, 394080, г. Воронеж, Госзаповедник \\ E-mail: sapelnikov@ reserve.vrn.ru; is@ reserve.vrn.ru
}

\begin{abstract}
Аннотация. Приведен ретроспективный анализ литературных данных о крапчатом суслике (Spermophilus suslicus Güldenstädt, 1770) за XVIII-XXI вв. в Центрально-Черноземном регионе и на сопредельных территориях. За 250 лет со времени описания вида по экземплярам из Воронежской губернии крапчатый суслик превратился из многочисленного в исчезающий. Предлагается рассматривать крапчатого суслика как синантропный вид, который при отсуствии преследования быстро привыкает к человеку. Неконфликтный вариант сохранения крапчатого суслика авторы видят через создание резервных популяций в рекреационных зонах под защитой человека. Вышеуказанным условиям предположительно могут удовлетворять некоторые региональные природные парки, базы отдыха, санатории, сафари-парки, семейные парки и другие территории, где в весенне-летнее время на природе постоянно присутствуют люди, но отсутствуют дикие и домашние хищники.
\end{abstract}

Ключевые слова: численность, распространение, восстановление вида, синантропность, рекреационная территория, редкие виды, крапчатый суслик.

Для цитирования: Сапельников С.Ф., Сапельникова И.И. 2021. Ретроспективный анализ состояния популяций крапчатого суслика (Spermophilus suslicus Güldenstädt, 1770) в Центральном Черноземье с сопредельными территориями и возможные пути сохранения вида. Полевой журнал биолога, 3 (2): 167-212. DOI: 10.52575/2658-3453-2021-3-2-167-212

\section{Retrospective Analysis of Condition of Populations of Spermophilus suslicus Güldenstädt, 1770 in Central Black Earth Region and in Adjacent Territories and Possible Ways of Preserving the Species}

\author{
Sergey F. Sapelnikov' ${ }^{1}$ Inna I. Sapelnikova ${ }^{2}$ \\ ${ }^{1}$ Lomovskoy Natural Landscape Park, \\ 2 Svobody Sq, Vorobievka vill., Vorobievskiy District, Voronezh Region, 397570, Russia \\ ${ }^{2}$ Voronezh State Natural Biosphere Reserve named after V.M. Peskova, \\ Goszapovednik, Voronezh, 394080, Russia \\ E-mail: sapelnikov@ reserve.vrn.ru; is@ reserve.vrn.ru
}

Abstract. A retrospective analysis of literary sources about the speckled ground squirrel (Spermophilus suslicus Güldenstädt, 1770) for the XVIII-XXI centuries in the Central Black Earth region and adjacent 
territories has been carried out. For 250 years since the description of the species from specimens from the Voronezh province, the speckled ground squirrel has turned from numerous to disappearing. In all regions, the decline in the number of speckled ground squirrels followed similar paths. As a result, rare settlements of the species survived only in anthropogenically transformed territories (summer cottages, cemeteries, oil refineries, roadsides, etc.). It is proposed to consider the speckled ground squirrel as a synanthropic species, which, in the absence of pursuit, quickly gets used to humans. The gopher can no longer independently survive and restore its numbers in the "wild" natural environment due to the negative impact of wild and domestic predators. The authors see a non-conflict option for preserving the speckled ground squirrel through the creation of reserve populations in recreational areas under the protection of humans. Some regional natural parks, recreation centers, sanatoriums, safari parks, family parks and other territories where people are constantly present in nature, but there are no wild and domestic predators, can presumably satisfy the above conditions.

Keywords: abundance, distribution, species recovery, synanthropy, recreational area, rare species, speckled ground squirrel.

For citation: Sapelnikov S.F., Sapelnikova I.I. 2021. Retrospective Analysis of Condition of Populations of Spermophilus suslicus Güldenstädt, 1770 in Central Black Earth Region and in Adjacent Territories and Possible Ways of Preserving the Species. Field Biologist Journal, 3 (2): 167-212. (In Russian.) DOI: $10.52575 / 2658-3453-2021-3-2-167-212$

Received May 25, 2021

\section{Введение}

Описание крапчатого суслика (Spermophilus suslicus Güldenstädt, 1770) было сделано профессором И.А. Гюльденштедтом [Gueldenstaedt, 1770] по воронежским экземплярам, собранным им в 1769 г. в ходе специальной академической экспедиции [Томановский, Попов, 1914]. За 250 лет после первого научного описания крапчатый суслик прошёл сложный исторический путь, на котором небывалый расцвет его численности сменился таким же небывалым истреблением вида, приведшим его в итоге на грань исчезновения. Особую тревогу за судьбу крапчатого суслика вызывают факты неуклонного сокращения его численности во многих частях ареала [Титов, 2001; Шилова и др., 2010; Русин, 2011; 2013; Ziółek et al., 2017]. Вид занесён в Красные книги Польши (EN) [Glowacinski et al., 2002], Беларуси (III, VU) [Демянчик, 2006], Украины (исчезающий) [Межжерин, 2009], в Красный список МСОП (NT) [Zagorodnyuk et al., 2008], в список редких видов животных к Красной книге РФ (2) [Ильяшенко и др., 2018; Приказ..., 2020]. В Центральном Черноземье и на сопредельных территориях крапчатый суслик занесён в Красные книги Белгородской (1) [Шаповалов, 2019], Воронежской (1) [Климов, 2018], Тамбовской (1) [Соколов, Лада, 2012], Брянской (1) [Ситникова, 2016], Ростовской (4) [Стахеев, 2014], Саратовской (2) [Беляченко, 2006] областей России и Харьковской (редкий) [Токарський, 2013а] области Украины.

Однако меры, принимаемые в традиционном формате, уже не могут остановить катастрофическое падение численности вида. На сегодня количество колоний вида в России, где сохранилось хотя бы 500 зверьков, можно пересчитать по пальцам одной руки, а популяций, где больше тысячи особей, очевидно, не осталось уже ни одной [Пиванова, Шубина, 2010; Титов и др., 2015; Проявка и др., 2017]. Ситуация крайне осложняется тем фактом, что в отличие от европейского суслика (Spermophilus citellus L.), с успехом разводимого в последние годы в ряде европейских зоопарков, крапчатый суслик пока не только не разводится, но даже не содержится в системе зоопарков [ЕАРАЗА..., 2005-2020]. То есть исчезновение крапчатого суслика из природы будет одновременно означать окончательную потерю его как биологического вида на планете Земля. 
Сегодня ситуация с крапчатым сусликом в России и сопредельных государствах всё больше напоминает судьбу странствующего голубя (Ectopistes migratorius) - эндемика Северной Америки, численность которого в XVI-XVIII веках достигала от 3 до 5 миллиардов (!) птиц, а уже в 1900 г. была убита последняя дикая особь. И всё это время учёных и энтузиастов, пытающихся поднять тревогу и сохранить вид, законодатели и другие авторитетные лица обвиняли в преувеличении трагизма и искажении ситуации. Незадолго до убийства последней птицы, осознав реальную опасность окончательной потери вида, странствующего голубя попытались развести в неволе, создав три племенных группы из немногих сохранившихся особей, но уже не смогли этого добиться. В итоге последний представитель вида - голубка Марта - умерла в зоопарке Цинциннати (штат Огайо, США) 1 марта 1914 года. Это было одно из величайших и самых бессмысленных антропогенных уничтожений вида в истории человечества [Смирнов, 2020].

Целью данной работы ставилось изучение ситуации с крапчатым сусликом в Центральном Черноземье и сопредельных областях на основе ретроспективного анализа литературных источников, включая как прошлые века, так и современность. Возможно, при таком подходе удастся лучше понять причинно-следственные связи, приведшие вид к назреванию трагической развязки, и удастся найти наиболее оптимальные пути и способы его спасения.

\section{Воронежская область}

История изучения крапчатого суслика в Воронежской области, где он впервые был описан, относительно подробно уже изложена в одной из предыдущих работ [Сапельников, Сапельникова, 2020а]. Мы посчитали уместным разместить частично данные указанной статьи в сокращенном виде здесь, что, по нашему мнению, должно способствовать созданию целостной картины о состоянии крапчатого суслика одновременно во всём регионе.

Описание вида оказалось тесно связанным с задачами Российского государства в XVIII веке. В конце XVII - начале XVIII вв. наступил новый период развития исследований в России, связанный с государственной политикой Петра I. Для комплексного исследования России первые научные экспедиции были направлены на побережье Северного Ледовитого океана, в Сибирь, на Камчатку [Русские экспедиции, библ. УрФУ]. Весной 1768 г. уже по распоряжению Екатерины II были сформированы две «физические» экспедиции: Оренбургская и Астраханская. Оренбургская включала три отряда, которые возглавили П.С. Паллас, И.И. Лепёхин и И.П. Фальк, Астраханская - два отряда под руководством С.Г. Гмелина и И.А. Гюльденштедта. В их задачу входило комплексное исследование природы, хозяйства и населения этих регионов [Русские экспедиции, библ. УрФУ].

Маршрут Астраханских экспедиций проходил через Воронеж. Прибыв сюда из Москвы 26 марта 1769 года, И.А. Гюльденштедт встретился с зимовавшим здесь С.Г. Гмелиным, и 10 апреля учёные выехали на обследование земель по правому берегу Дона. Посетив Кастинск (Костёнки), Яблоново (Яблочное), Урыв, Острогожск, Дивногорский монастырь, Коротояк и другие поселения, они ночью 20 апреля вернулись в Воронеж. Чтобы наиболее эффективно охватить территорию дальнейших исследований, путешественники составили план летних маршрутов и отправили его в Императорскую Академию Наук на рассмотрение, которая утвердила его и прислала обратно. Согласно этому плану С.Г. Гмелин должен был идти на Азов через Острогожск, Павловск, Черкасск и Царицын, с зимовкой в Астрахани, И.А. Гюльденштедт - на Тамбов, Новохопёрск, УстьМедведицу и Царицын, с зимовкой также в Астрахани [Гмелин, 1806].

Из Воронежа И.А. Гюльденштедт выехал 6 мая и доехал в этот день только до с. Чижовки (ныне центр города). С 7 по 11 мая он находился в Таврове, затем, «не при- 
держиваясь обычной дороги», отправился в Усмань-Собакину (село Новая Усмань), где оставался до 15 мая. Далее направился в город Орлов (село Орлово), «который на карте старого русского атласа не отмечен между обеими Усманями». С 16 мая и в последующие дни учёный проезжал через деревню Привалы (Большая и Малая Приваловки), Первый, Второй и Третий Байгор (Верхняя, Нижняя и Княжная Байгоры), «где находится переправа через реку Байгору». Затем учёный «ехал вёрст 30 по степи, в которой, в 20 верстах от Третьего Байгора, переночевал в палатке у реки Плавицы, впадающей в реку Мотыру, и ботанизировал до 26-го мая». Далее, проехав Чамлык, путешественник остановился в «Мордове на Битюге» и пробыл там до 1 июня. С 1-го по 3-е июня он находился у истока речки Пласкуши, впадающей в Битюг. В Липовце на речке Липовице он опять оставался ещё несколько дней и «наконец, 6-го прибыл в Тамбов». Учёный пишет: «В доселе пройденных степях, почти с каждой остановки, я предпринимал экскурсии вёрст на 15-30 в сторону, чтобы как следует изучить местность». И далее: «Степи населены многочисленными грызунами, из которых наиболее обыкновенные байбак, суслик и хомяк» [Томановский, Попов, 1914, с. 115-116].

Из Тамбова И.А. Гюльденштедт прибыл в Новохопёрскую крепость и пробыл там больше месяца. Здесь учёный описал флору и фауну данной местности, включая млекопитающих. «Байбаки, суслики, хомяки, белки, куницы, горностаи, ласки, хорьки, волки, лисицы, барсуки, зайцы и ежи часто встречаются в степях и лесах в окрестностях крепости. Очень обыкновенен также зверок, копающий землю, как крот; русские называют его слепцом, я же назвал его Spalax и описал в трудах русской Императорской Академии Наук» [Томановский, Попов, 1914, с. 120].

Описание слепыша (сразу рода и вида) поступило в редакцию Novi Commentarii Academiae Scientiarum Imperialis Petropolitanae 21 сентября 1769 г. [Gueldenstaedt, 1770a], но перед этим (дата не указана) уже было принято от учёного описание крапчатого суслика - Mus suslica [Gueldenstaedt, 1770]. Тип был описан по экземплярам из окрестностей Воронежа, а также из местности между Воронежем и Тамбовом и из долины реки Дон («Habitat animal frequenter in campis vastissimis tanaicensibus, praecipue urbes Woronesch et Tambov») [Gueldenstaedt, 1770; Огнев, Воробьёв, 1923; Огнев, 1947; Россолимо, 1987]. Из всех видов сусликов крапчатый суслик был описан вторым в мире после европейского суслика (Spermophilus citellus L., 1766) [Соколов, 1977] и первым среди 9 видов сусликов России [Павлинов и др., 2002]. Описание было снабжено довольно наглядным чернобелым рисунком суслика, а также его черепа видом снизу и сверху. Кроме того, рисовальщиком экспедиции Григорием Белой (Белым) в год описания был сделан ещё и акварельный рисунок, очень наглядно передающий характерный облик вида (см. рисунок).

Многочисленность крапчатого суслика была отмечена исследователями как на восток от Воронежа, так и в южном от него направлении. С.Г. Гмелин [1806], поначалу называя суслика «восточным хомяком», пишет: «Понеже начал я говорить о зверях, то при сем случае намерен также упомянуть о некоторой породе восточнаго хомяка, которых в Донских степях, начиная от Воронежа даже до Черкаскаго, такое изобилие находится, что не трудно было бы на каждый день ловить их по 50». С учётом трудности «выливания» зверьков из нор, о чём автор говорит ниже, этот вывод можно уверенно считать очень высоким показателем обилия вида в то время. И далее: «Но я с тем большею краткостию буду об нем говорить, понеже мне известно, что оный от отправленнаго вместе со мною в Астраханскую губернию учёнаго гос. докт. Гилденстета описан будет обстоятельно в комментариях Императорской Академии Наук» [Гмелин, 1806, с. 47]. 


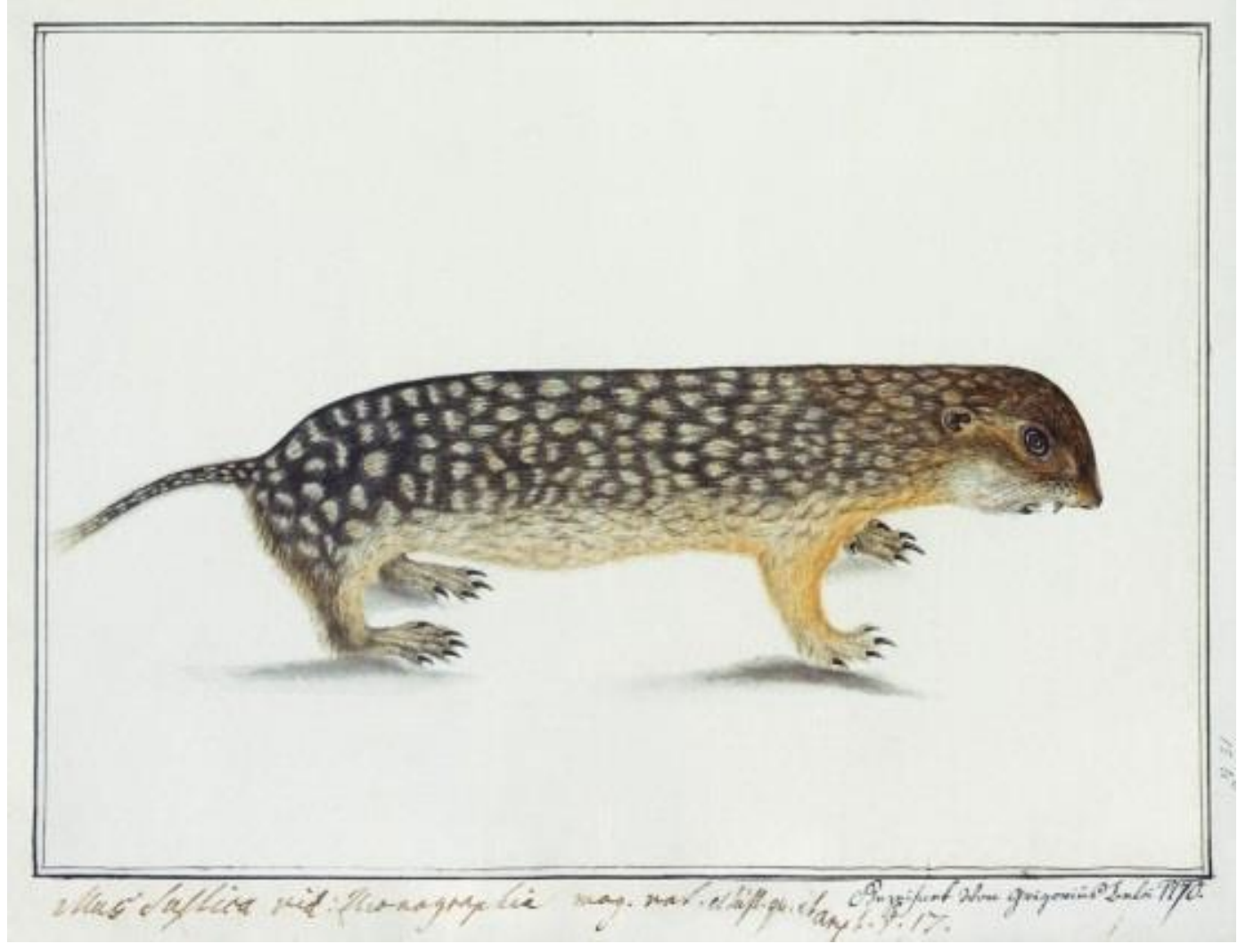

Первый цветной рисунок крапчатого суслика (рисовальщик Григорий Белой). Подпись на рисунке: «Mus suslica vid: Uconographia mag.» (далее неразборчиво) § 17» Авторская подпись «Grigorii Beloi 1770». По нижнему краю неразборчивая скоропись. Справа внизу: «15».

(Из архива Санкт-Петербургского филиала Архива Российской Академии наук)

The first colored drawing of a speckled ground squirrel (draftsman Grigorii Beloi).

Caption on the picture: "Mus suslica vid: Uconographia mag." (further illegible) § 17" Author's signature

"Grigorii Beloi 1770 ". Unreadable cursive along the bottom edge. Bottom right: "15".

(From the archive of the St. Petersburg branch of the Archive of the Russian Academy of Sciences)

В следующий раз российская наука уделила внимание крапчатому суслику только в XIX веке, спустя более 80 лет после его описания. Случилось это благодаря инициативе и выдающимся способностям студента Московского государственного университета Н.А. Северцова, который под руководством профессора К.Ф. Рулье проводил свои ежегодные наблюдения на территории Воронежской губернии с 1844 по 1853 гг. Результатом этой работы стал вышедший в 1855 г. фундаментальный труд «Периодические явления в жизни зверей, птиц и гад Воронежской губернии» [Северцов, 1950].

В этой сводке автор приводит название крапчатого суслика как Spermophilus citillus L. (var. guttata), суслик (без русского видового), смешивая при этом название западного (или европейского) суслика - Mus citellus L., 1766 [Огнев, 1947] и тёмную морфу крапчатого суслика из Среднего Поволжья - Mus citillus [Pallas, 1770], Mus citellus var. guttata Pall., 1770 [Огнев, 1947]. При этом название, данное виду при его описании на воронежской земле, - Mus suslica [Gueldenstaedt, 1770] или светлого крапчатого суслика - Citellus (Citellus) suslica suslica Güld. (1769-1770) [Огнев, 1947] автором не упоминается.

И хотя суслик не был у Н.А. Северцова предметом специального изучения, ему удалось создать в целом реальное представление о состоянии популяции вида того времени. Выяснилось, что в одних районах суслик наблюдался в бо́льшем количестве, в других - в меньшем. Отмечалось, что в степи между Битюгом, Доном и Икорцем суслик, «как и хомяк, ...уменьшается числом особей». Не обнаружив сусликов в «сырых и потных» степях по «верхам Икорца» автор связывает это с «изменением в свойстве чернозёма». Одна- 
ко дальнейшие исследования показали, что суслик редок в частях степи, смежных с Икорцем, но далее от реки, в более сухих частях степи, он многочислен.

Далее Н.А. Северцов пишет, что в Каменной степи, характеризующейся «рыхлым и сухим чернозёмом», появляется «нормальное для наших степей количество землекопов». Подчёркивая многочисленность сурков, он указывает, что «...их образ жизни такой же, как в Икорецкой степи, но хомяки, не водящиеся там, здесь живут так же, как и суслики, в одной местности с сурками...». Кроме того, учёный отмечает, что в центральных частях Каменной степи нет чёрного хоря, но водится перевязка, которая живёт в норах. Этот факт свидетельствует о достаточно благополучном состоянии в это время местных популяций видов-жертв перевязки - обыкновенного хомяка и крапчатого суслика.

Анализируя влияние глубокой вспашки «при поднятии нови», учёный говорит о её «истребительской» роли для крупных землекопов - сурков, сусликов, хомяков, слепышей, перевязки. Кроме того, во время работы крестьян на полях и пастбищах их постоянно сопровождают собаки, истребляющие грызунов «в большом количестве». В целом автор констатирует негативную роль антропогенного влияния на зверьков: «И теперь на полях и залежах есть хомяки, а особенно суслики, но они малочисленны; весьма немногие перенесли необходимость изменения в своём образе жизни» [Северцов, 1950, С. 99, 106, 108].

В 1892 г. при Лесном Департаменте России была образована Особая Экспедиция, в задачи которой входили научные изыскания на казённых землях среднерусской черноземной области - в Воронежской, Харьковской и Екатеринославской губерниях. В Воронежской губернии в качестве степного участка ставилась задача обследовать Каменную степь. Зоологические сборы и обследования проводил здесь в 1894-1896 гг. А.А. Силантьев.

У исполнителя так же, как и у Н.А. Северцова, не стояла задача выяснения правильного систематического положения вида, поэтому им дано было крапчатому суслику употребляемое на границе XIX-XX веков латинское название Spermophilus guttatus Temm. - без года описания и каких-либо пояснений [Силантьев, 1898]. В современной систематике такого названия нет, как не существует и ранее описанных похожих подвидов [Виноградов, Аргипуло, 1941; Огнев, 1947; Соколов, 1977; Павлинов, Россолимо, 1987; Россолимо, 1995; Павлинов, Россолимо, 1998; Павлинов и др., 2002].

По данным А.А. Силантьева, суслики встречаются на всех участках, но в Каменной степи за все три года наблюдений их было очень мало. Исполнитель отмечает, что численность крапчатого суслика в Бобровском уезде в последние годы сильно снизилась благодаря сусликовой повинности, когда ежегодно истреблялось до 50000 зверьков и более. В связи со снижением численности вида эта повинность в 1895 году была отменена.

Возможно, что именно по причине низкой численности А.А. Силантьев не вносит крапчатого суслика в число вредителей сельского и лесного хозяйства региона. К вредителям им отнесены майский жук, июльский хрущ, зайцы, водяная крыса и «мыши» (все мышевидные грызуны). Но крапчатого суслика среди них нет [Силантьев, 1898].

Следующий этап изучения фауны Воронежской губернии был по-настоящему научным и масштабным, но пришелся на годы Гражданской войны и проводился в сложной обстановке 1919-1922 гг. экспедициями С.И. Огнева [Огнев, Воробьёв, 1923]. В систематическом плане это была образцовая работа, основы которой используются по сегодняшний день.

По интенсивности окраски у С.И. Огнева наметились два подвида суслика, описанные в 1770 г. в одном и том же академическом издании Novi Commentarii Academiae Scientiarum Imperialis Petropolitanae: 1) основной южный, описанный на полторы сотни страниц раньше, Citellus suslicus suslicus Gueld.; 2) более тёмный северный - Citellus suslicus guttatus Pall. Однако между этими формами имеются многочисленные переходы, что затрудняет идентификацию особей и проведение границ подвидов [Огнев, Воробьёв, 1923].

В отличие от данных А.А. Силантьева, во время работы экспедиции С.И. Огнева в Каменной степи сусликов было уже довольно много (10-20 нор на десятину $(1,1$ га)). 
Также в большом количестве их нашли в Старо-Курлацкой, Нечаевской и Зыковской степях Бобровского уезда. Но особенно много сусликов отмечалось в Валуйском уезде, где на десятину приходилось до 300 нор, хотя до 80 \% нор оказывались часто незанятыми.

В целом для района исследований подвид C. s. suslicus Gueld. определён С.И. Огневым как обыкновенный, а подвид C. s. guttatus Pall. - как редкий. Отмечается также, что в период поспевания хлебов суслики перебираются на поля и наносят ощутимый вред (только у одной норки было насчитано 400 объеденных в разной степени колосков). Кроме наблюдений в природе автором описывается поведение сусликов в неволе, возможности их приручения, содержания и выращивания [Огнев, Воробьёв, 1923].

За всю историю зоологических исследований на территории Воронежской области по-настоящему полноценные результаты по крапчатому суслику были получены в 19511954 гг. экспедициями кафедры зоологии позвоночных ВГУ под руководством профессора И.И. Барабаш-Никифорова [Барабаш-Никифоров, 1957]. В этой работе много места уделено описанию биологии вида - питанию, размножению, зимовке, врагам и болезням; приведены наблюдения за зверьками в неволе. Описаны этапы развития борьбы с сусликами, проанализирована в духе того времени эффективность отдельных методов. И.И. Барабаш-Никифоров указывает, что среднегодовые заготовки шкурок за 1946-1953 гг. составили 1425032 штук. Организация многочисленных экспедиций позволила выяснить распределение плотностей популяции крапчатых сусликов в регионе. Было показано, что в те годы этим видом в разной степени была заселена вся Воронежская область и сопредельные северные и юго-западные территории. В центральных и южных районах области плотность вида доходила до 50 жилых нор на 1 га, а среднегодовая добыча - до 400 зверьков на 1000 га. На востоке области, в окрестностях Хопёрского заповедника, средняя плотность сусликов по левобережью Хопра также достигала свыше 50 жилых нор на 1 га, но на правобережье она была низкой - до 20 нор на 1 га [Барабаш-Никифоров, 1957].

В 1949-1950 гг. в окрестностях Хопёрского заповедника была отмечена вспышка численности крапчатого суслика, плотность нор на отдельных участках достигала 144 на 1 га. При этом подъём численности затронул лишь левобережье, на правобережье при специальном обследовании в 1950 г. суслики не были найдены. В последующем резких повышений численности этого вида не регистрировалось. Тем не менее, материалы 1950-х годов из окрестностей Хопёрского заповедника свидетельствуют о высокой доле крапчатого суслика в питании ряда хищных птиц: чёрного коршуна (Milvus migrans) (16\%), большого подорлика (Aquila clanga) (42\%), орла-карлика (Hieraaetus pennatus) (55\%) и особенно балобана (Falco cherrug) (80 \%) [Королькова, 1975]. Последние наиболее крупные колонии сусликов были отмечены вокруг болота Вырубное и соединённого с ним болота Головко. К началу 1990-х годов сохранилась колония только на выгоне на месте бывшего хутора Кольцовский. С 1992 г. суслики в окрестностях заповедника окончательно перестали встречаться [Марченко, 1996; 2003; 2016; Марченко, Печенюк, 2000].

Однако в отдельных местах Новохопёрского района суслики обнаруживались ещё около 10 лет. Зверьков наблюдали в 2001 и 2002 гг. южнее с. Пыховки на левобережье реки Пыховки, при этом было найдено несколько жилых нор. Однако в 2003 г. этот участок распахали и сусликов здесь больше не видели. По непроверенным данным суслики какоето время ещё встречались южнее с. Каменка-Садовка и западнее с. Ивановка [Печенюк, 2005]. Возможно, что это были последние встречи крапчатого суслика на территории Воронежской области.

На территории Воронежского заповедника первое упоминание крапчатого суслика мы находим в работе К.К. Сент-Илера, проводившего здесь исследования с 1 мая по 1 сентября 1933 г. [Сент-Илер, 1934]. Главной целью работ ставилось получение данных о кормовых запасах заповедника для выпуска в его угодья некоторых экзотических зверей скунсов, серебристо-чёрных лисиц, американских норок и енотовидных собак. Учитывалось всё, пригодное этим видам в пищу. Одним из обследуемых участков стала большая 
поляна на левом берегу реки Усмани в кварталах 35 и 47 (нынешние кв. 294 и 315, Оброчное поле). Отмечается, что поляна окружена высоким лесом, по ней протекает ручей; частично засеяна овсом и засажена картофелем, остальное - луг. Здесь, почти в 4-х км от опушки леса, участниками экспедиции был визуально отмечен типично степной вид крапчатый суслик, как очень редкий вид. Определён он был как подвид Citellus suslicus guttatus Pall., при этом подвид Citellus suslicus suslicus Gueld., тоже внесённый в подготовленную для работы таблицу, не был обнаружен [Сент-Илер, 1934]. Учитывая ещё и «чрезвычайно неблагоприятное» лето 1933 года, когда «почти беспрерывные дожди в начале лета делали работу невозможной», обнаружение суслика на поляне в лесу при вынужденно редких полевых выходах становится ещё более удивительным. Этот факт может свидетельствовать, скорее всего, о существовании здесь полноценной популяции, при высокой численности которой некоторые особи могут находиться на поверхности земли и при плохой погоде.

Нереальный на первый взгляд факт обитания степного вида на лесной поляне в глубине леса может быть объяснён относительно недавним введением заповедного режима, до которого Оброчное поле использовалось как пастбище. Сохранившиеся до наших дней набитые скотом глубокие стёжки вдоль ручья Змейки от с. Большая Приваловка до Оброчного поля наглядно подтверждают такую версию. Суслики, как обычный пастбищный вид на рубеже XIX и XX веков, могли расселиться по прогону скота вдоль ручья до самого поля и существовать на этом пастбище неопределённо длительное время. С введением заповедного режима выпас коров прекратился и прогон зарос лесом. Поляна поначалу частично распахивалась под овощные культуры, но потом была брошена и заросла высокотравьем, превратившись в сенокосные угодья с редким посещением людей. В итоге суслики изолированной популяции, оказавшись в заросшем и обезлюдевшем месте, быстро исчезли.

Позднее при подробной инвентаризации фауны позвоночных животных Воронежского госзаповедника отмечалось, что крапчатый суслик «встречается на смежных с заповедником полях, довольно многочислен на лугу близ села Беляево, откуда отдельные особи изредка проникают на окраинные лесные поляны» [Барабаш-Никифоров, Павловский, 1948, с. 38]. Во втором аннотированном списке позвоночных заповедника, подготовленном всего через 40 с небольшим лет, уже подчёркивалось падение численности вида: «Очень редок. Обитает постоянно. Встречается на степных и луговых участках охранной зоны заповедника» [Лавров и др., 1992, с. 36]. В последнем издании аннотированного списка высказывалось опасение окончательного исчезновения крапчатого суслика из окрестностей заповедника. При этом отмечалось, что последние «разрозненные поселения зверьков находились на пастбищах в охранной зоне заповедника, у его северной опушки» [Сапельников, 2008, с. 67].

Последний раз пребывание крапчатого суслика у границ заповедника зарегистрировано на территории Усманского района Липецкой области в 2003 г. в ходе плановых работ по изучению хищных птиц. 9 июля при осмотре нами гнезда могильника (Aquila heliaca) в нём было обнаружено 2 черепа суслика, а 25 июля под этим же гнездом была найдена свежая шкурка этого вида с черепом. При этом на содранной шкурке зверька сохранился довольно толстый слой жира, что свидетельствовало о благополучной подготовке сусликов к зимовке. Однако весной 2004 г. при попытке проведения учёта сусликов по норам-веснянкам в районе аэродрома, напротив кв. 1-4, мы не смогли найти ни одной свежей норки и ни разу не услышали свиста зверьков. Все осмотренные сусликовины оказались необитаемыми (не считая их использования полёвками). Не были обнаружены суслики в этом районе и в полевые сезоны 2005-2006 гг., что с большой вероятностью свидетельствовало об окончательном исчезновении вида из этих мест [Сапельников, Венгеров, 2007]. 
Определяющую роль в сохранении оптимальных биотопов для сусликов у границ заповедника играло местное животноводство. До 1992 года численность отары овец, выпасаемой в районе летнего база с. Шаршки, доходила до 9 тыс. голов, что не допускало на пастбищах высокотравья и очень благотворно влияло на условия обитания сусликов. Однако с началом в стране перестройки всё хозяйство резко пошло на убыль и к концу ХХ века полностью прекратило своё существование. Однако даже в условиях зарастающих пастбищ популяция сусликов сохранялась ещё более 10 лет, несмотря на её генетическую изолированность. Вероятно, немалую позитивную роль в этом сыграло регулярное кошение находящегося здесь аэродрома для сельскохозяйственной, а позже - для малой авиации [Сапельников, Венгеров, 2007].

К сожалению, за всю научную историю заповедника не был введён мониторинг численности популяции крапчатого суслика в его охранной зоне, вследствие чего данные по экологии вида и его динамике здесь отсутствуют.

Историческое присутствие крапчатого суслика вокруг границ заповедника косвенным образом подтверждается гнездованием в XX веке могильника по опушке лесного массива. Кроме северной окраины леса у аэродрома факты регулярного гнездования могильника отмечены в районе Центральной усадьбы заповедника в юго-восточной его части и у с. Ступино, на юго-западной опушке леса [Сапельников, Венгеров, 2007].

Опросные сведения также подтверждают былое обитание крапчатого суслика в данных районах. Так, сотрудница Воронежского заповедника Л.И. Деревенских помнит, что, будучи школьницей 10-11 лет, она с подругами в середине 1960-х годов наблюдала сусликов на выгоне за селом Малая Приваловка у границы заповедника, где пасли коров.

Житель села Беловка Верхнехавского района А.И. Баскаков также помнит по своему детству, что мальчишкой 8-9 лет в конце 1980-х годов видел сусликов за селом на пастбище между озёрами Ступинское и Орлиное. Он тогда помогал отцу стеречь коров, который ему и рассказал, что наблюдаемые ими зверьки называются сусликами.

О наличии колонии сусликов в 1990-х годах прошлого века у села Ступино Рамонского района сообщил житель села В.О. Артёмов. Суслики жили на поле в конце села, но после застройки этого места дачами они исчезли.

Существование в XX веке поселений сусликов в районе села Беляево и колхозного аэродрома у кварталов 1-4 подтверждается ещё и небольшим коллекционным материалом Воронежского заповедника в количестве 6 тушек [Сапельников, Сапельникова, 2020а].

Исчезновение крапчатого суслика из природной среды обитания происходит обычно тихо и незаметно. Нередко это не сразу замечают даже местные жители, постоянно работающие в полях. В сознании людей обычно откладывается наличие в угодьях зверьков, а не их отсутствие. Возможно, по этой причине при сборе опросных сведений по суслику получаются более оптимистичные данные, чем они есть на самом деле, что в итоге напрямую влияет на природоохранный статус вида в регионе. Когда же наконец выясняется реальная картина катастрофического снижения численности вида в регионе, ему в следующем издании Красной книги присваивается сразу одна из высших категорий редкости, но часто это бывает уже с большим опозданием. Так, во второе издание Красной книги Воронежской области крапчатый суслик занесён сразу с категорией 1 - исчезающий вид. Но сохранять, похоже, уже стало некого, так как сведения о находках сусликов поступили только из двух точек области - из Павловского и Богучарского районов, да и то документально неподтверждённые [Климов, 2018].

На примере Воронежской области мы видим определённо трагическую последовательность развития событий в отношении крапчатого суслика - от его первого научного описания до вероятного исчезновения вида из природных биотопов региона. Подавляющее большинство изданных работ посвящено организации и проведению борьбы с сусликом как с вредителем сельского хозяйства. Даже чисто научные изыскания в итоге обычно сводились к рекомендациям по сокращению численности вида. Изучение суслика (дина- 
мика численности, распределение, экология, генетика и др.) стало отдельным предметом исследований только после катастрофического падения его численности.

\section{Липецкая область}

Первое упоминание о суслике в Липецкой области мы находим в работе П.Н. Данилова, посвящённой в первую очередь отрядам рукокрылых и насекомоядных бывшего Елецкого уезда Орловской губернии. На последней странице в разделе IV, посвящённом грызунам, в списке видов сразу после белки идёт суслик с лаконичной записью: «Род Суслик. Arctomis. Sehreb. (орфогр. сохранена - авт.). Суслик рябой. A. rufescenses. Keys. Попадается часто» [Данилов, 1868, с. 32]. И в данном случае даже не важно, насколько правильно сделана видовая запись и её соответствие зоологической систематике, важнее то, что вид «попадается часто», так как речь шла, несомненно, о крапчатом суслике. В дальнейшем, по истечении более полувека, крапчатый суслик в Елецком, Ливенском и в ряде других уездов Орловской губернии по-прежнему продолжал встречаться «очень часто» [Горбачёв, 1925].

В 1951-1953 гг. сотрудниками кафедры зоологии Воронежского университета под руководством проф. И.И. Барабаш-Никифорова было проведено экспедиционное и стационарное изучение фауны позвоночных животных южной части Липецкой области вплоть до Липецка. Согласно полученным результатам, плотность популяции крапчатого суслика на обследованной территории колебалась от средней на юго-востоке (от 20,1 до 50 жилых нор на 1 га) до низкой на северо-западе (до 20 жилых нор на 1 га). Однако такой численности оказалось достаточно, чтобы на стационаре в б. Водопьяновском районе (ныне с. Донское Задонского района) получить необходимый материал по строению нор суслика. При этом отмечается, что студентка А.В. Алёхина, проводившая по поручению руководителя раскопку нор, обнаружила в них кладовые с зёрнами злаков (до 600 г), чего ни разу не отмечалось в Каменной степи и в Гремяченском районе Воронежской области [Барабаш-Никифоров, 1957].

Несомненную научную ценность представляет студенческий отчёт 1970-х годов по фауне наземных позвоночных заповедника «Галичья гора» и его окрестностей проф. С.М. Климова, опубликованный коллегами уже после его смерти. О крапчатом суслике автор пишет: «...Многочисленный вид, обитающий в степных участках урочища Морозова гора, Галичья гора и Быкова шея. В июне 1973 г. плотность нор суслика на выгоне у северной границы ур. Морозова гора составила 35 нор на 1 га, из них 27 (77,7 \%) были жилыми. В 1975 г. на 2 га площади в том же месте учтено 43 норы, из которых только 7 (16,2\%) оказались жилыми. Уменьшение численности на этом участке связано с интенсивным выпасом овец, вследствие чего почва здесь сильно утоптана, а растительность съедается овцами» [Климов, 2010, С. 80]. В данном случае автором подчёркивается негативная роль случающегося перевыпаса, приводящая к потере кормовых стаций для суслика и покиданию видом обжитых мест.

В 2010 г. сравнительные учёты нор в этих же местах на двух участках были проведены С.В. Пивановой [2011]. Результаты показали, что за прошедшие три-четыре десятилетия численность крапчатого суслика здесь заметно снизилась, о чём свидетельствовало падение числа нор с 35-43 на 1 га до 10,2-14,4 на 1 га [Пиванова, 2011].

В июне 1982-1983 гг. в окрестностях Лесостепной опытной селекционной станции (ЛОСС) (Становлянский район) были обнаружены поселения крапчатого суслика на склонах оврагов в правобережной части р. Локотцы. В одном из них насчитывалось 18 жилых нор с численностью сусликов до 30 особей [Александров, Недосекин, 1998; Недосекин, 2009].

В 1990-1991 гг. на территории заповедника «Галичья гора» (Задонский район Липецкой области) и в его окрестностях студенткой Воронежского университета И.Э. Здешневой проводилось выявление факторов, определяющих распространение крапчатого сус- 
лика в этом регионе. Наиболее благоприятными для вида оказались используемые под выпас пологие остепнённые склоны речных долин, луга высоких пойм, а также пологие склоны балок. Здесь в результате выпаса скота формируется травостой с проективным покрытием 60-70 \% и высотой не более 30 см. В таких местообитаниях плотность нор достигает 35-45 на 1 га. Наименее привлекательными для зверьков стали прирусловые валы средней поймы (10-16 нор/га) и кустарниковые степи на склоне долины (6-9 нор/га), где из-за нерегулярного выпаса и близости речного русла сформировалась растительная ассоциация с проективным покрытием 90-100 \% и средней высотой травостоя 45-50 см. На основании полученных данных автор работы приходит к логичному выводу, что в условиях современного лесо-полевого ландшафта крапчатый суслик особенно охотно заселяет интенсивно выпасаемые участки, имеющие низкий травостой и мягкие почвы с глубоким залеганием грунтовых вод [Здешнева, 1992].

В конце XX века, характеризуя региональную фауну позвоночных животных, липецкие учёные считали крапчатого суслика повсеместно распространённым обычным видом, наибольшая численность которого регистрировалась в местообитаниях на Среднерусской возвышенности. Однако уже тогда отмечали заметное снижение численности вида в последние два десятилетия [Недосекин и др., 1996]. Основной причиной этого могла стать значительная антропогенная трансформация природных экосистем, приводящая к постепенному исчезновению из них целого ряда позвоночных животных, включая и крапчатого суслика [Климов и др., 1994]. Сокращение численности этого вида в известных местообитаниях ещё более наглядно продолжилось в первые годы XXI века. Если в заповедных урочищах Морозова гора и Галичья гора и их окрестностях раньше было 9 поселений при численности от 6 до 45 нор на гектар [Здешнева, 1992], то через 15 лет их сохранилось лишь 4. При этом в двух из них осталось менее 6 нор, в остальных - не более 29. Основной причиной такой депрессии численности вида, по мнению учёных, явилась сильная фрагментированность и изолированность его поселений. Для подъёма численности крапчатого суслика предлагалось проведение мероприятий по его искусственному расселению в подходящие местообитания [Недосекин, Ушаков, 2005]. Сообщается, что «проводившийся в 2001 г. выпуск 30 особей на Морозовой горе и её окрестностях (суслики были отловлены из поселения, расположенного в 20 км северо-восточнее от места выпуска), вероятно, послужил стимулом наращивания численности сусликов в сохранившихся поселениях» [Недосекин, 2007, с. 134].

Результаты анализа современного состояния вида как в границах Центрального Черноземья, так и на севере Среднерусской возвышенности подтвердили его устойчивую тенденцию к сокращению в конце XX века [Недосекин, 2007; Пиванова, 2009]. При этом подчёркивается вся широта комплекса экологических факторов, действующих на популяцию крапчатого суслика, а также их высокая динамичность. Отмечается, что в современных условиях стациями переживания крапчатого суслика являются обочины дорог, кладбища, овраги, балки, где воздействие многих факторов сказывается в меньшей степени [Пиванова, Шубина, 2009].

Одним из последних мест обитания крапчатого суслика в Липецкой области стали окрестности урочища Плющань заповедника «Галичья гора» в Краснинском районе. Здесь в сохранившемся местообитании у южной границы заповедного участка 30.04.2011 насчитано 40 нор на 20 га площади бывшего выгона крупного рогатого скота [Недосекин, 2014]. Чуть позже сообщалось, что вид в малом числе ещё встречается в окрестностях урочищ Морозова гора, Быкова Шея, Воронов Камень, Плющань [Недосекин, 2016]. Однако в последние годы обнаружить сусликов в точках прежних регистраций в природных местообитаниях Липецкой области больше не удалось (В.Ю. Недосекин, личное сообщение).

В конце 1980-х годов крапчатого суслика регистрировали в городской черте Липецка. В парке Победы он встречался единично (0,7 особи на 1 га), при этом зверьки в поисках пищевых отходов повадились посещать свалки. Наиболее подходящим местообита- 
нием крапчатого суслика в черте областного центра являлись остепнённые склоны Каменного лога. Здесь он считался обычным видом, и плотность его нор достигала 28 шт/га [Климов, Александров, 1993]. В работе по изучению склонности позвоночных животных к синантропизации в ряду от мыши-малютки до бобра анализировались и тенденции с крапчатым сусликом. Отмечалось, что обитание этого вида на городских свалках свидетельствует о наличии «определённого резерва синантропных начал». Но при этом высказывалась обеспокоенность за суслика в связи с резким падением его численности из-за интенсификации сельского хозяйства [Константинов и др., 1996, с. 7]. В конечном итоге крапчатый суслик из вышеуказанных местообитаний Липецка постепенно исчез, причиной чему скорее всего явился комплекс городских негативных факторов (В.Ю. Недосекин, личное сообщение).

Крапчатый суслик мог бы окончательно исчезнуть с территории Липецкой области, но вид каким-то чудом удержался в несвойственном для него местообитании - на городском кладбище у с. Косырёвка, что примерно в 5 км от Липецка. Также зверьки продолжали обитать на окружающих резервных землях, откуда они, по всей видимости, и появились на кладбище, а также на ближайших дачах. С начала нынешнего века за колонией стали вести наблюдения сотрудники кафедры географии, биологии и химии Липецкого государственного педагогического университета им. П.П. Семёнова-Тян-Шанского. Результаты десятилетней работы дают достаточно полное представление о состоянии, биологии, поведении и других характеристиках сохранившейся в Центрально-Черноземном регионе популяции крапчатого суслика.

Косырёвское кладбище - крупнейшее в Липецке и его окрестностях, занимает площадь 60 га, открылось в 1987 г. [Косырёвское кладбище..., 2019]. До открытия кладбища сусликов отмечали в близлежащих оврагах и на обочинах дорог. По сведениям смотрителей, зверьки появились на кладбище примерно в начале 1990-х годов и с тех пор их поселение постоянно расширяется, но заселение территории проходит неравномерно. Общая численность сусликов на кладбище составляет около 700 особей, что соответствует 12 зверькам на 1 га [Пиванова, Шубина, 2010]. На сегодня это одна из самых крупных популяций восточного полувида $(2 \mathrm{n}=34)$ [Загороднюк, Федорченко, 1995; Павлинов, Лисовский, 2012] крапчатого суслика, сохранившихся в России.

При опросе населения на Косырёвском кладбище и соседних дачах $(\mathrm{n}=80)$ выяснилось, что более 90 \% респондентов относятся к сусликам негативно, заливая норы водой, ставя капканы и разбрасывая отравленные приманки [Пиванова, 2008]. Негативное отношение к зверькам садоводов и посетителей кладбища подтвердилось и в последующие годы, однако отмечается, что такие действия носят неорганизованный характер и не оказывают существенного влияния на состояние популяции [Пиванова, Шубина, 2010б].

Изучение сезонной активности показало, что пробуждение зверьков на кладбище приходится примерно на конец марта (25.03.2007 и 16.03.2008), наибольшая их численность наблюдается с 20-х чисел мая по 20-е числа июня (выход молодняка), а массовое залегание в спячку происходит в середине августа (17-25 августа). В итоге общая продолжительность активного периода сусликов в природно-антропогенном ландшафте составляет около 160 дней [Пиванова, 2008а].

При изучении характера размещения жилых нор выяснилось, что больше всего их находится на территории кладбища (978 нор/га) и прилегающих резервных землях, где не проводится никакой хозяйственной деятельности (1034 нор/га). В балке Студёный лог, условия которой должны быть наиболее приближены к природной среде, этот показатель составил всего 100 нор/га. Число наклонных нор (условно временных) превышало вертикальные (условно постоянные): на кладбище - в 2 раза, на резервных землях - в 14 раз, в Студёном логу - в 1,5 раза. При этом доля старых нор в балке оказалась очень высокой и составила $46,5 \%$, что могло свидетельствовать о происходящем сокращении численности вида в этом биотопе [Пиванова, 2009а; Чичина и др., 2009]. 
Для изучения питания сусликов этой колонии основным методом было выбрано наблюдение за кормящимися зверьками. Параллельно изучали остатки пищи на «кормовых столиках» у нор, а также проводили опрос населения на дачных участках. В итоге выяснилось, что суслики кроме типичной для них растительной пищи в значительной степени используют продукты питания человека, особенно сладости - конфеты, печенье и пр. На дачах зверьки поедали клубнику, капусту, реже - спаржевые, луковицы тюльпанов и корни петрушки. То есть пища сусликов этой популяции довольно разнообразна, но в то же время не совсем типична, так как зверьки в значительной степени употребляют продукты питания человека [Литвинова и др., 2009].

При оценке эпидемиологического значения «косырёвской» колонии учёные напоминают, что суслики, как и другие грызуны, являются переносчиками возбудителей опасных болезней домашних животных и человека. Актуальность вопроса возникла в связи с превышением здесь санитарно-эпидемиологических норм по численности вида более чем в 2 раза, массовым заражением зверьков эктопаразитами и находкой за апрель 2009 г. на кладбище 7 мёртвых особей, что позволяет предполагать вероятность инфекционного заболевания. В целях предупреждения распространения зоонозных инфекционных болезней и, одновременно, сохранения вида от бесконтрольного истребления, предлагалось регулировать численность популяции путём переселения части особей на территории, где суслик в настоящее время исчез [Пиванова, Шубина, 2009а].

Данные по размножению крапчатого суслика в «косарёвской» популяции получены по материалам вскрытия 33 половозрелых самок, погибших по разным причинам на кладбище в весенне-летний период 2009 г. Кроме того, в сезоны 2008-2009 гг. проводились наблюдения за семью выводками сусликов. Результаты исследований показали, что доля размножающихся самок составила 90,9 \%. Предполагается, что высокий процент размножающихся самок обусловлен компенсаторной реакцией популяции на значительную гибель особей от различных причин, обусловленных хозяйственной деятельностью человека при сохранении достаточной кормовой базы и мест для размножения. Среднее количество эмбрионов у самок данной популяции $(5,6 \pm 0,3)(\operatorname{Lim} 2-9)$. Среднее число детёнышей в выводке - 4,4 [Пиванова, Шубина, 2010а].

По данным 135 учётов, проведённых в 2006-2008 гг. на Косырёвском кладбище, примыкающих полях и соседних садоводческих участках, выяснилось, что наибольшая плотность населения крапчатого суслика наблюдается на самом кладбище - 1220 особей/км ${ }^{2}$. На нераспаханном поле численность зверьков была значительно ниже - около 350 особей/км ${ }^{2}$, на садовых участках - ещё меньше, приблизительно не более 5 особей/км². Плотность распределения сусликов по кладбищу различалась по давности захоронений. Наиболее плотно населён зверьками средневозрастный участок (около 1550 особей/км²), менее освоен участок с последними захоронениями (около 1150 особей/км ${ }^{2}$ ) и участок с первыми захоронениями (примерно 980 особей/км ${ }^{2}$ ). Территорию со свежими захоронениями суслики осваивают по мере формирования травяного покрова, а участок с первыми захоронениями зверьки постепенно покидают из-за его зарастания древесно-кустарниковой растительностью и исчезновения кормовых растений [Пиванова, Шубина, 2010б].

Для изучения морфологической изменчивости крапчатого суслика в Центральной части европейской России группой учёных сравнивались выборки популяций из Липецкой, Тамбовской и Брянской областей. Также в сравнительный анализ были включены данные И.В. Загороднюка и А.А. Федорченко [1995] по Курской и Луганской областям. Результаты исследования показали, что более крупные зверьки характерны для Липецкой области, где многочисленная популяция данного вида населяет городское кладбище с благоприятными кормовыми и защитными условиями обитания [Проявка и др., 2017].

Косырёвскую популяцию крапчатого суслика как самую крупную на территории Центрального Черноземья мы имели возможность использовать в 2015-2019 гг. в качестве 
донорской для отработки методики реинтродукции вида. Необходимость поддержки слабых природных популяций, обоснованной реинтродукции и расселения переуплотнённых колоний с антропогенно трансформированных территорий в природу неоднократно подчёркивалась рекомендациями учёных [Недосекин, Ушаков, 2005; Демянчик, 2006; Недосекин, 2007; Пиванова, Шубина, 2009а; Ситникова, 2016; Шекарова, Савинецкая, 2019]. В некоторых региональных Красных книгах отмечается, что специальные биотехнические мероприятия для восстановления численности вида в природе не разработаны [Плечова и др., 2010; Стахеев, 2014], специальные охранные меры не предпринимались [Титов, 2005; Климов, 2018; Шаповалов, 2019].

Известны лишь единичные случаи преднамеренной интродукции сусликов Палеарктики (род Spermophilus) за пределы естественного ареала. При этом из трёх переселений в научных целях крапчатого (S. suslicus), малого (S. pygmaeus) и большого $(S$. major) сусликов успешной оказалась только интродукция $S$. major. При этом в качестве вероятных причин отрицательных результатов для малого суслика указывался частый возврат холодов в весенний период [Александров и др., 2019].

Опыт наших работ по реинтродукции крапчатого суслика, включающий как успехи, так и неудачи, изложен в ряде обобщающих публикаций [Сапельников, 2019; Сапельников, Сапельникова, 2019; Сапельников, Сапельникова, 2020; Сапельников, Сапельникова, 2020a; Sapelnikov, Sapelnikova, 2019]. Здесь же предлагаются пути реализации проектов по реинтродукции вида, в наибольшей степени обеспечивающие сохранность зверьков и приживаемость их на новом месте.

\section{Тамбовская область}

Целенаправленно полевой материал по наземным позвоночным Тамбовской губернии стал собирать в начале XX века С.А. Предтеченский. Основные данные по орнитологии были получены им в 1910-1920 гг. (с перерывом в 1916-1917 гг.) преимущественно в Тамбовском уезде. В дальнейшем, в 1920-1924 гг., попутно с коллектированием птиц проводились сборы и других позвоночных животных. Ежегодные экскурсии охватывали территорию Спасского уезда с прилегающими участками Елатомского, Темниковского и Шацкого уездов. При этом, как указывает автор, «юго-восточная часть губернии осталась без исследований». Тем не менее общее число коллекционных экземпляров достигло около 1000 номеров (789 птиц, 98 млекопитающих и 100 гадов). Результаты работ были систематизированы по классам с присвоением каждому виду и подвиду условной оценки численности [Предтеченский, 1928]. Согласно данным С.А. Предтеченского, суслик крапчатый - Citellus suslicus guttatus Pall. в то время здесь был так же обычен, как и подавляющее большинство млекопитающих губернии. Многочисленнее этой группы были только землеройка обыкновенная, полёвка обыкновенная и крыса водяная - почти повсеместно фоновые виды мелких млекопитающих с характерными для них вспышками численности.

Как было показано выше, в систематическом плане к тому времени уже наметились два подвида крапчатого суслика: 1) основной, южный, описанный под Воронежем И.А. Гюльденштедтом как Mus suslica [Gueldenstaedt, 1770); 2) более тёмный, северный, описанный в Среднем Поволжье С.П. Палласом как Mus citillus с особым вариететом var. guttatus (Pallas, 1770). Основной, более светлый подвид впоследствии стал значиться как Citellus suslicus suslicus Gueld. 1770, более тёмный, северный - как Citellus suslicus guttatus Pall. 1770 [Огнев, Воробьёв, 1923]. Описывая сусликов Бобровского уезда Воронежской губернии и просмотрев очень большую серию экземпляров из Воронежской, Харьковской, Киевской, Рязанской, Тульской, Орловской и Нижегородской губерний, С.И. Огнев отнёс местных зверьков к основному подвиду - C. s. suslicus Gueld. При этом учёный отмечает, что «для нас почти не подлежит сомнению, что в северных частях Воронежской губ. (Землянский и Задонский у.у.) преобладает Citellus suslicus guttatus Pall. Изредка не отличимые от него особи встречаются и южнее, в Бобровском у., но здесь это сравнительно редкие 
исключения» [Огнев, Воробьёв, 1923, с. 156]. Возможно, именно поэтому С.А. Предтеченский, зная работу С.А. Огнева и ссылаясь на неё по другим видам, отнёс тамбовских сусликов к северному подвиду с более интенсивной окраской - C. s. guttatus Pall. Своих конкретных доводов по поводу такого решения автор в данной статье не приводит.

При зональном описании губернии С.А Предтеченский [1928] отмечает, что суслики и тушканчики начинают встречаться уже на территории лесного района, в его южной части: «Из южных видов в этом районе найдены тушканчик Alactaga saliens, суслик Citellus suslicus, малая выпь Ardetta minuta и орёл-карлик Hieraёtos pennatus». Фауна следующего, лесостепного района «обогащается за счёт представителей степной зоны, из числа которых здесь обитают тушканчик, суслик, степная пеструшка...». Характеризуя северозападный подрайон, С.А. Предтеченский указывает, что здесь ещё до революции остались нераспаханными несколько маленьких участков целинной степи, самый северный из которых - «Ямская степь» расположен в 12 верстах на юго-запад от Тамбова. Автор подчёркивает, что по мере удаления от границ лесостепного района «суслики и тушканчики здесь становятся более обычными, так же, как и некоторые южные виды птиц» [Предтеченский, 1928, с. 12-13].

В духе своего времени исследователь выделяет главу о вредных млекопитающих, куда наравне с обыкновенной полёвкой и волком относит и крапчатого суслика (серая крыса и домовая мышь упоминаются здесь больше как синантропные виды). Здесь же приводится и краткое описание распределения и биологии вида.

Автор сообщает: «Суслик распространён по всей губернии, однако количество его постепенно редеет в северном и северо-западном направлении. Особенно много сусликов обитает в юго-восточных волостях Борисоглебского уезда, где он временами причиняет более или менее значительные повреждения хлебам. По восточной окраине черноземных почв северных уездов суслик выходит за пределы современной губернии, заходя местами в пределы елово-лесного района. Довольно много сусликов я наблюдал в северовосточной части Спасского уезда». Далее учёный пишет: «На юге Тамбовского уезда я уже много сусликов наблюдал 10 мая 1920 г. В Спасском уезде 27 июля 1921 г. я много сусликов встречал у нор по дороге Спасск-Кошелевка» [Предтеченский, 1928, с. 30].

Примечательно, что ключевым во всех этих описаниях является термин «много», что, безусловно, отражало фактическую численность крапчатого суслика в начале XX века в Тамбовской губернии. Ранее И.А. Гюльденштедт, прибыв 6 июня 1769 г. со своей экспедицией из Воронежа в Тамбов, сделал аналогичную запись в своём дневнике: «Степи населены многочисленными грызунами, из которых наиболее обыкновенные байбак, суслик и хомяк» [Томановский, Попов, 1914, с. 116].

По сути дела, материалы статьи С.А. Предтеченского продемонстрировали достаточную стабильность высокой численности тамбовской популяции суслика за 150 -летний период, ещё со времени описания вида в XVIII веке. При этом резкое снижение за это же время численности байбака автор объясняет высоким прессом охоты и браконьерством. В главе о промысловых и охотничьих животных он пишет: «Вследствие отсутствия гделибо правильного охотничьего хозяйства, целый ряд ценных животных находится накануне полного уничтожения. Таковы из млекопитающих: бобр, байбак, лось и медведь» [Предтеченский, 1928, с. 31]. Надо полагать, что в этом отношении суслику, как неохотничьему виду, на данный отрезок времени повезло гораздо больше.

Однако чуть позже в стране были развёрнуты против суслика масштабные истребительные мероприятия со сдачей шкурок государству, в которые вовлекалась и молодёжь. По итогам конкурса юных охотников-ловцов 1950 г., объявленного Всесоюзным объединением Заготживсырьё Министерства заготовок СССР и ЦК профсоюза работников мукомольной и элеваторной промышленности, отличились и юные тамбовчане. Так, в Мучкапском районе Тамбовской области юный ловец Николай Коростелев сдал 11000 штук шкурок суслика, из них 75 процентов без дефекта, Николай Ломов сдал 
6000 шкурок, из них 83 процента без дефекта. При этом все отличившиеся по стране ловцы получили денежные премии [Павлова, 1951].

Несмотря на повсеместное массовое истребление, крапчатый суслик до середины XX века был в Тамбовской области обычным видом, распространённым «по всем открытым пространствам области». При этом он по-прежнему признавался вредителем сельского хозяйства, подлежащим истреблению [Будниченко и др., 1964, с. 112]. Но к 1965 г. его численность резко сократилась, причём так же, как обыкновенного хомяка, большого тушканчика и дрофы. При этом такие виды, как степной сурок, обыкновенный слепыш, стрепет и степной орёл исчезли полностью. Причиной этому, по утверждению учёных, явилась усиленная распашка земель [Асоскова, Херувимов, 1966]. Спустя 15 лет уже предполагалось, что крапчатый суслик в регионе «почти исчез» [Херувимов, 1981]. Критическое положение вида подтверждалось сравнительными учётами. Если под Тамбовом на одном и том же участке Татарского вала в 1967 г. насчитывали 30 нор суслика на километр маршрута, то в 1997 г. этот показатель составил лишь 3 норы [Соколов, Лада, 2000].

К 1999 г. в области было известно единственное относительно крупное поселение, расположенное по обочинам автотрассы Москва - Астрахань и на склонах виадука Озерки - Дмитриевка в Никифоровском районе. Здесь 18 июня 2005 г. отмечено визуально и по голосам 54 особи крапчатого суслика [Сапельников и др., 2007; Яценко, Сапельников, 2007; Соколов, Лада, 2012]. Наблюдения за колонией показали, что у зверьков выработались эколого-этологические адаптации к антропогенно трансформированной среде, что можно рассматривать как обнадёживающую перспективу выживания вида в современных условиях [Сапельников и др., 2007а]. Однако реконструкция виадука в 2010-2013 гг. привела к полному уничтожению колонии, места с последними норками были частично заасфальтированы [Смыкова, Родимцев, 2014]. К результатам научных исследований, которые учёные успели здесь провести, можно отнести лишь прижизненное получение морфологической характеристики её особей в сравнении с другими колониями в ареале вида [Проявка и др., 2017].

В то же время в Мичуринском районе в сентябре 2010 г. было найдено сразу 11 небольших колоний крапчатого суслика, количество нор в которых варьировало от 4 до 27. Сами зверьки на этот момент уже давно находились в спячке. Колонии располагались в 23 км к югу от городских окраин Мичуринска, на заброшенных лугах и полях левого берега p. Лесной Воронеж, в условном треугольнике между сёлами Борщевое, Устье и Стаево. Отдельные норы сусликов были найдены на склонах и вершине дамбы, отделяющей отстойники от р. Лесной Воронеж. В мае 2011 г. после тщательного осмотра территории здесь было найдено всего 87 нор, из них 49 вертикальных и 38 наклонных. Зверьки вели себя осторожно, прячась в норы от человека за 50-100 м. Однако здесь же, на расстоянии около 800 м друг от друга были обнаружены два жилых лисьих «городка» с черепами и другими костными фрагментами сусликов, что вызвало обоснованное беспокойство за дальнейшую судьбу колонии [Родимцев, 2012].

Обследование территории в мае - июне 2013 г. показало, что три небольших колонии сусликов исчезли, но зато были найдены ещё три ранее неизвестных поселения, состоящие из 12, 8 и 19 нор. Всего же их общее количество, включая и нежилые, составило 104 норы. Наиболее вероятной причиной исчезновения части колоний явилось продолжающееся хищничество лисицы, у жилой норы которой (всего в 300-400 м) обнаружены черепа и кости сусликов [Смыкова, Родимцев, 2014]. Дальнейшая судьба этого поселения неизвестна, но с учётом историй целого ряда «затухающих» колоний, в итоге окончательно исчезнувших в Центральном Черноземье, можно предположить, что надежда на её сохранение до настоящего времени в условиях естественной природной среды предельно мала. Для выяснения современного состояния данных колоний (вероятно, последних в Тамбовской области), необходимо тщательное обследование всего района находок, включая и прилежащие территории. 


\section{Ростовская область}

В Красной книге Ростовской области крапчатому суслику (Spermophilis suslicus) присвоена категория 4 - неопределённый по статусу вид [Стахеев, 2014]. Его ареал захватывает лишь небольшой участок в самой северной части Ростовской области. Юговосточная граница ареала в первой половине XX в. проходила от р. Деркул в Луганской области на северо-восток через станицы Мальчевскую, Кудиновскую, Мешковскую, Казанскую и Шумилинскую, т. е. почти полностью совпадала с северо-западной границей распространения малого суслика [Свириденко, 1940; Белик, 2011]. В начале 1950-х годов крапчатого суслика обнаруживали на Цимлянском полуострове [Стахеев, 2014].

Как отмечает проф. В.П. Белик [2011], основные данные по крапчатому суслику были получены здесь ещё в первой половине XX века П.А. Свириденко [1927, 1940] и с тех пор практически не дополнялись, а лишь перепечатывались из одной сводки в другую. Новых находок вида на Нижнем Дону, по-видимому, никто из зоологов больше не отмечал. С учётом же критического состояния вида в соседних регионах [Загороднюк, 2006] не исключено, что на территории Ростовской области этот вид уже исчез [Белик, 2011].

Подтверждением этого тревожного предположения могли бы стать результаты работы экспедиции Института проблем экологии и эволюции имени А.Н. Северцова РАН в июне - августе 1992 г. в Чертковском районе Ростовской области. Всего здесь в различных биотопах с помощью живоловок Н.А. Щипанова и плашек Геро было отработано 5850 ловушко-суток, поймано 936 зверьков 9 видов [Шилова и др., 1994]. Однако в реальности экспедиция была загружена выполнением конкретных запланированных задач, в число которых поиски сусликов не входили (Л.Е. Савинецкая, личное сообщение).

В 1997, 2002 и 2004 гг. пензенскими учёными были предприняты попытки изучения современного состояния зоны парапатрии малого ( $S$. pygmaeus) и крапчатого (S. suslicus) сусликов на территории от Северского Донца до Волги. Вдоль границ ареалов было пройдено более 800 км маршрута и обследовано 73 точки, более половины из которых предыдущими исследователями отмечены как места обитания сусликов. В итоге были найдены только единичные малочисленные поселения малого суслика вблизи Волги (Саратовская область), а крапчатого суслика не удалось найти вовсе. На месте былой зоны интерградации малого и крапчатого сусликов не только не выявлены следы гибридизации, но и практически отсутствовали исходные виды [Быстракова и др., 2005].

Проф. В.П. Белик [2011] сообщает о своих личных поисках этого вида: «Наши поиски крапчатого суслика в июле 1992 г. на р. Деркул на маршрутах протяженностью около 40 км в районе с. Волошино Миллеровского района тоже оказались безрезультатными. Там на выгонах у села была найдена лишь одна колония малого суслика. В июне 1994 г. на 75 км маршрутов по Чертковскому и Миллеровскому районам в верховьях р. Калитва удалось обнаружить еще одну плотную колонию сусликов, располагавшуюся на пастбищах в долине реки у подножия меловых склонов ниже с. Кудиновка, но идентифицировать видовую принадлежность этих животных нам не удалось. Однако, судя по отсутствию сусликовин, там могли еще обитать крапчатые суслики» [Белик, 2011, с. 106].

Другими авторами отмечается находка небольших колоний крапчатого суслика в 90-е годы XX в. в Чертковском (1990 г., хутор Зубрилинский, до 10 особей) и Миллеровском (1989 г., западнее села Мальчевское, до 10 особей) районах [Миноранский и др., 2015]. Кроме этого, в печати было также высказано утверждение, что «в 2007-2011 гг. данного суслика на Дону никто не отмечал...» и, на основании этого, предположение, что «возможно, он здесь не встречается» [Добровольский, 2013, с. 10]. К аналогичному выводу в своих исследованиях пришли и другие авторы, склоняясь к мысли, что в настоящее время крапчатый суслик в Ростовской области находится на грани полного исчезновения [Симонович, Сидельников, 2014]. 
В то же время есть мнение, что в северо-западных районах области возможно обнаружение отдельных небольших поселений. При этом отмечается, что специальные меры охраны вида не разработаны [Стахеев, 2014].

В итоге одни учёные склоняются к выводу, что на территории Ростовской области крапчатый суслик не встречается или находится на грани исчезновения [Симонович, Сидельников, 2014; Миноранский и др., 2015], другие же считают, что необходимо активизировать здесь поиски этого редкого и слабо изученного вида, так как только они позволят ответить на вопрос о судьбе крапчатого суслика на Дону [Белик, 2011, Стахеев, 2014].

\section{Курская область}

В 1919 г. Московское общество испытателей природы (МОИП), существующее при Московском университете с 1805 г., образовало первую в России биологическую научную станцию в д. Старое Першино Дмитриевского уезда Курской губернии. Последним заведующим биостанцией с 1926 г. до её закрытия в 1930 г. был известный зоолог Е.С. Птушенко. Он активно включился в работу по изучению фауны позвоночных, район его исследований охватил территорию запада современной Курской области в бассейнах рек Свапы, Суджи, Сейма и Северского Донца (совр. Белгородская область). Позже он стал первым зоологом, сделавшим описание орнитофауны и териофауны ЦентральноЧерноземного заповедника [Власов, 2013].

Результаты полевых работ того времени оценивались в первую очередь по объёмам собранных научных коллекций. Всего за время работы на биостанции, включая первую командировку Е.С. Птушенко от МОИП сюда в 1923 году, им было собрано 875 экземпляров шкурок млекопитающих. Кроме того, учёным были просмотрены коллекции ряда районных музеев края, а также материалы заготовительных пунктов пушнины в Дмитриевском, Льговском, Рыльском и Курском районах. Также им были изучены более ранние публикации других авторов, что дало возможность ретроспективного анализа состава фауны и численности ряда её представителей вплоть до XV века. При этом всем зверям, занесённым в таблицу, автор присваивал соответствующую им категорию статуса в цифровом значении от 0 до 6 - от «случайно появляющийся вид» до «весьма обыкновенный», отмечая соответствующими значками и динамику численности вида.

Из 56 фактически отмеченных Е.С. Птушенко видов и подвидов млекопитающих суслик Курской области был представлен учёным в двух формах: Citellus suslica guttatus Pall. (1770) - северный крапчатый суслик и Citellus suslica suslica Güld. (1770) - южный крапчатый суслик. По «северному» подвиду табличные данные приведены, начиная с XV века, по «южному» - только с XVIII, но везде обе формы значатся под цифрой 5 как «обыкновенные». Однако в начале XX в. картина заметно изменилась - оба подвида из «обыкновенных» переводятся Е.С. Птушенко в «довольно редкие», т. е. «5-3».

Тем не менее при отлове совместно с Н.А. Гладковым необходимой выборки зверьков для выяснения границы подвидов на более обширной площади края учёные, судя по всему, не испытывали каких-либо затруднений. Более того, территория между гг. Дмитриевом, Льговом и Рыльском, рассматриваемая на тот момент В.Г. Плигинским как разрыв ареалов между северным и южным подвидом, оказалась также полностью заселена крапчатым сусликом. Относительно указанных форм Е.С. Птушенко пишет, что «точное определение и сравнение наших сборов со сборами из б. Воронежской и б. Орловской губ. показало, что на территории б. Курской губ. встречаются обе морфы и C. suslica guttatus Pall., и C. s. suslica Güld., причём первая встречается чаще». В то же время автор указывает на определённую ненадёжность критерия пятнистости, присущего больше возрастным изменениям: «Необходимо отметить, что степень пятнистости на нашей серии в 32 экземпляра значительно вариирует и носит не расовый, а возрастной характер. Именно у большинства взрослых пятна редкие, у большинства же молодых пятнистость гуще» [Птушенко, 1937, с. 439]. 
Однако при этом автор всё же определяет для региона примерные границы обитания указанных форм: «Чем далее продвигаться к югу и юго-востоку от б. Дмитриевского у., тем чаще начинает попадаться форма C. s. suslica Güld., и в бассейне pp. Оскола и Сев. Донца наряду с переходными формами она уже вполне хорошо выражена. В Казацкой степи вблизи г. Курска встречается Citellus suslica guttatus Pall. (сборы Н. Кабена)». Исходя из этого и делая в конце статьи вывод об исторически смешанном характере фауны края, Е.С. Птушенко среди некоторых других близких форм (тёмный и светлый хорь и др.) приводит в пример также «северный» и «южный» подвиды крапчатого суслика - Citellus suslica guttatus и Citellus suslica suslica [Птушенко, 1937, C. 439].

При анализе биотопического распределения млекопитающих оба подвида сусликов отмечены учёным только в открытых биотопах - на открытых песках со скудной растительностью, пахотных полях с нераспахиваемыми межами, остатках степи с участками сохранившейся, «прозябающей» степной флоры и, что особенно характерно, вдоль дорог того времени. Автор пишет: «Широкие 30-метровые ленты дорог, так называемые шляхи, разрезают Курский край по различным направлениям и по существу являются просёлочными путями, только более широкого, чем обычно, типа. Для езды используется почти всегда 2-3 колеи и только в грязь шлях весь изъезжен. И на самых шляхах, и, главным образом, на их обочинах ютится разнообразная широко распространённая сорная растительность. Из млекопитающих здесь селятся Citellus suslica guttatus, Citellus s. suslica и Alactaga jaculus jaculus» [Птушенко, 1937, с. 459].

Одновременно с научными исследованиями в стране продолжалась и масштабная борьба с сусликом, в том числе и с целью сдачи шкурок государству. Объёмы заготовок шкурок суслика в регионе выражались тогда в десятках и сотнях тысяч штук, что свидетельствовало о довольно высокой численности вида в этих местах: «...В 1926-1927 гг. по ЦЧО заготовлено 118139 шкурок сусликов, в 1927-1928 гг. 314374, в 1928-1929 гг. 98471, в 1932 г. 562710 , в 1933 г. 912931, в 1934 г. по Воронежской области - 208102 и по Курской - 20782 шкурки» [Птушенко, 1937, С. 440].

После закрытия Першинской биостанции планомерное отслеживание состояния биоты продолжил на своих участках Центрально-Черноземный заповедник (ЦЧЗ). Крапчатый суслик здесь впервые был отмечен на территории Стрелецкого и Казацкого участков в мае - июне 1937 г. [Птушенко, 1940]. Примерно до конца 1940-х годов он был достаточно многочисленным видом луговой степи. Касаясь группы землероев Стрелецкой степи, Г.М. Зозулин писал: «На первом по количеству месте нужно поставить суслика, вредителя сельскохозяйственных культур, распространению которого, впрочем, не мешают и обработанные поля, в тех случаях, когда с ним ведётся слабая борьба. Вред, причиняемый сусликом народному хозяйству, и его усиление в отдельные годы на степи заставляют в заповеднике время от времени его отлавливать» [Зозулин, 1950, С. 58].

В 1950-1960-е годы крапчатый суслик уже не был так многочислен, но всё ещё считался обычным видом заповедных степных участков [Елисеева, 1959]. При обследовании участка Баркаловка в 1970-1972 гг. он был отмечен в степной части лога Подгородного, но уже как редкий вид [Елисеева, 1977].

К середине 1990-х годов суслик ещё обитал здесь на всех участках ЦЧЗ, но везде уже был немногочислен. На Стрелецком участке к тому времени сохранились две небольших колонии численностью не более 80-100 особей. На Казацком и Ямском участках численность была значительно ниже. На Баркаловке, Букреевых Бармах и Лысых Горах суслик был уже очень редок и лишь единично отмечался в местообитаниях, граничащих с агроландшафтами. Численность этого вида резко сократилась с 40-х годов, когда его стали отлавливать из-за причинения им вреда степной растительности. Кроме прямого воздействия на популяциях сусликов отрицательно сказались фрагментация их поселений и зарастание пастбищных участков высокотравьем [Власов, 1995]. Редкость крапчатого суслика на Казацком участке подчёркивалась также И.С. Денисовой, проводившей здесь в 
1993-1995 гг. изучение фауны мелких млекопитающих. Но считать этот вид исчезнувшим, по мнению ученого, было бы преждевременно из-за сложности обнаружения его колоний при минимальной численности [Денисова, 1996].

Чуть позже сообщалось, что популяция крапчатого суслика на Казацком участке находится в крайне угнетённом состоянии. Отмечалось, что за последние годы здесь не было зарегистрировано ни одной визуальной встречи этих зверьков [Денисова, 1997].

К началу XXI века с территории Казацкого участка и Баркаловки суслик окончательно исчез, а на Ямском участке и Букреевых Бармах встречался единично. Небольшая популяция численностью около 100-150 особей сохранилась лишь на Стрелецком участке. Создавшееся критическое состояние вида было обусловлено целым комплексом усугубляющихся причин: увеличением высоты и густоты травяного яруса луговой степи, интенсивным применением химических средств защиты растений, увеличением общей гумидности климата в регионе за последние 30 лет, распашкой оставшихся участков степной целины, прямым истреблением, инсуляризацией оставшихся популяций и общей депрессией численности. В силу этого усилилась опасность дальнейшего сокращения численности вида [Власов, 2001]. Вскоре он был занесен в Приложение к первому изданию Красной книги Курской области [Красная книга..., 2002]. Однако ситуация продолжала оставаться критической, и в 2006 г. суслик был рекомендован к занесению в Красную книгу Курской области [Власов, Власова, 2006].

Тем не менее в последующие годы численность крапчатого суслика в Стрелецкой степи продолжала неуклонно падать, и к концу первого десятилетия XXI века последняя популяция вида в Центрально-Черноземном заповеднике прекратила своё существование [Брандлер и др., 2012]. В 2011 г. в рамках проекта ПРООНГЭФ «Совершенствование системы и механизмов управления ООПТ в степном биоме России» в Обоянском, Пристенском, Солнцевском, Горшеченском и Касторенском районах Курской области в апреле и мае - июне были проведены полевые исследования степного сурка и специальные поиски поселений крапчатого суслика. Однако суслики нигде не были обнаружены, что может свидетельствовать об окончательном исчезновении вида не только в заповеднике, но и на территории Курской области [Власов, Брандлер, 2011].

\section{Белгородская область и Украина}

История образования Белгородской области и её границ на протяжении последних столетий была достаточно сложной. Возможно, в том числе и по этой причине в литературе не обнаруживается цитируемых биологических публикаций прошлых веков, касающихся изучения крапчатого суслика конкретно на данной территории. Следует также отметить, что по всей южной России, включая соседнюю Харьковскую губернию, проблема вреда от сусликов сельскому хозяйству в XIX веке стояла настолько остро, что выяснение этого вопроса входило в задачи государственных комплексных экспедиций. Такая экспедиция была предпринята по поручению Императорского Харьковского университета «для описания некоторых южных губерний России в естественно-историческом и сельскохозяйственном отношениях». В 1849-1851 гг. с целью описания сусликов, обитающих в южной России, и способов их истребления в ней принимал участие Николай Черняев. Результатом его работы стала монография о биологии сусликов и мерах борьбы с ними, удостоенная по конкурсу Учёным Комитетом Министерства Государственных Имуществ золотой медали [Черняев, 1857].

Анализируя причины распространения сусликов в степях южной России, автор связывает этот процесс с увеличением населения средних и южных губерний страны. «Плуг, соха и сам человек, с сопровождающими его домашними животными, постепенно вытесняли сусликов из занимаемых ими пространств средней России, заставляя их поселяться в обширных и обильных степях южной России. Поэтому более населённые и менее богатые степями (необработанными землями) губернии, каковы: Воронежская, Курская, Чернигов- 
ская, и некоторые уезды Харьковской и Полтавской и другие, прежде обильные этими зверьками, в настоящее время не претерпевают никакого вреда, подобно Херсонской, Екатеринославской и др. губерниям. Поселившись в степях южной России, суслик здесь, год от году, более и более, стесняет пределы своего местожительства, по причине увеличивающегося в значительной степени скотоводства (в особенности овцеводства) и земледелия; последнее лишает его местностей, удобных для рытия нор; первое же, уничтожая в большом количестве растительные вещества, заставляет его нападать на хлебные посевы» [Черняев, 1857, с. 39].

Последнее утверждение автора о вытеснении сусликов расширяющимся скотоводством получило с течением времени иную, противоположную оценку, свидетельствующую об оптимальных условиях пастбищных биотопов для жизнедеятельности суслика. Так, на примере Елисаветградского уезда Херсонской губернии довольно ясно прослежена последовательность заселения сусликами подходящих угодий, а также отмечены условия, благоприятствующие увеличению их численности [Махно, 2005].

Автор сообщает, что в начале XIX столетия в районе с. Солоного (южная часть уезда), по сведениям старожилов, сусликов было совсем мало - не более 2-3 особей на 100 десятин (109 га). И селились они не на хлебных полях и сенокосах, а на бугристых и твёрдых выгонах и выпасах поблизости от деревушек и хуторов, лишённых больших садов и кустарников. Впервые этих зверьков обнаружили ещё до образования села на склоне некой балки Мечетная, где из-за плохой почвы отсутствовали большие бурьяны и высокая трава. С появлением же здесь людей и домашнего скота суслики стали переселяться на выгоны и выпасы поселян, постепенно удаляясь по ним вглубь полей, выбирая при этом места с покатостями и без высоких трав и бурьянов. Позже, с основанием с. Сербуловка, суслики по таким же «коридорам» постепенно пришли и в его окрестности [Махно, 2005].

Повествуя о ходе заселения сусликами Херсонской губернии, автор логично связывает численность сусликов с ощутимостью и степенью вреда от них крестьянству: «...В 50-х годах суслики уже встречались во многих местах, но вред от них в то время был такой незначительный (в виде небольших выбоин по окраинам полей), что на них хозяева не обращали никакого внимания, и даже из-за таких пустяков считали грехом уничтожать Божье создание, которому нужно же было чем-нибудь питаться; да притом не думали они и не гадали, чтобы такой незначительный зверёк, каким его считали тогда, со временем его размножения мог стать опасным врагом их полей, тем более, что суслики вообще на пахотных полях селились мало, а на мягких полях, особенно же на парах, их и совсем не было. Это больше всего и дало повод думать нашим хозяевам, что суслик не есть опасный враг хлебам» [Махно, 2005, с. 8].

Далее, с увеличением народонаселения в сельской местности, стала возрастать и численность сусликов, а также приносимый ими вред: «...Там, где прежде были непролазные бурьяны и высокие травы, остававшиеся нетронутыми круглый год, и где суслики селились неохотно и даже совсем их не было, там стали ходить стада и сеяться хлеб, от чего поля представляли больше простора и удобства для обиталища сусликов, которые в сухое время года из пастбищ и сенокосов переходили на поля и наносили им всё больший и больший вред, так что в половине семидесятых годов они уже сделали в первый раз посевам значительный ущерб. Только после этого наш крестьянин узнал, что суслик для него не безвредный зверёк; однако он, считая вред, нанесённый сусликами его полям, как "попущение Божье", счёл для себя грехом идти против наказанья, посылаемого, как они говорили, Богом за грехи». Одновременно у местных крестьян стало проявляться «нерадение к правильному обсеменению полей», люди «перестали орать пар», что увеличило площади оптимальных для сусликов биотопов и спровоцировало увеличение их численности». «...В этих годах сусликов приблизительно насчитывалось на десятине средним числом до 25 штук, а на всех надельных землях наших крестьян (до 5000 десятин) их было до 100000 штук» [Махно, 2005, с. 8-9]. 
Дальнейшее непринятие мер по улучшению принципов земледелия и сдерживанию численности сусликов привело к сильному осложнению ситуации. «...С 1883 года суслики заселили всю нашу местность, так что не было ни одного клочка земли, где бы их не имелось и где бы они не сделали хотя небольшого вреда. Особенно чувствительное опустошение они произвели в 1884 году. В этом и последующем году на десятине насчитывали до 40 штук, а на всей земле наших крестьян до 200000 штук; с этого же года крестьяне и начали их больше истреблять» [Махно, 2005, с. 11].

Описанный пример почти 90-летнего развития популяции крапчатого суслика наглядно демонстрирует определяющую роль в этом процессе освоения человеком новых земель, сопровождающегося развитием скотоводства и земледелия. Суслики быстро расселялись из менее подходящих природных биотопов, нетронутых человеком, на более оптимальные для них территории - пастбища, выгоны и окраины полей, где максимально реализовывался их репродуктивный потенциал. За почти вековую историю описанной популяции не случилось никакой её депрессии от перевыпаса скота, а наоборот, произошёл неуправляемый рост её численности, приобретший форму стихийного бедствия. Это ещё раз подтверждает ошибочность выводов Н. Черняева о сдерживающей роли скотоводства (особенно овцеводства) для популяций суслика, причём материалами его современника, полученными почти на той же территории.

Применительно же к нашему времени, когда стратегия по крапчатому суслику направлена не на уничтожение, а на его спасение как исчезающего вида, работу А. Махно можно рассматривать как описание примера успешного развития разреженной популяции суслика в естественной среде до уровня высокопроизводительного питомника. Однако простейшие расчёты показывают, что для реализации аналогичного проекта понадобится маточное поголовье сусликов с минимальной численностью 10-15 тыс. особей (исходя из 2-3 особей на десятину и необходимой площади в 5000 десятин) и почти 90 лет ожидания результата, что, безусловно, не может быть предметом серьёзного обсуждения. Эти доводы в очередной раз напоминают о бесперспективности попыток создания в наше время резервных популяций крапчатого суслика в естественной среде обитания и одновременно о необходимости разработки этого направления в условиях вольерных питомников на базе ООПТ [Сапельников, 2019; Сапельников, Сапельникова, 2020].

Изучение степени влияния суслика на урожайность возделываемых культур продолжалось и позже Н. Черняевой и А. Махно. В начале XX века исследования всё больше стали концентрироваться на изучении биологии вида, включая в первую очередь плотность распределения по регионам и биотопам или, как стали называть, «заражённость» сусликом посевных и сопредельных с полями площадей.

В числе особенно проблемных территорий оказалась Харьковская губерния. Исследования начала XX в. показали, что заселена она крапчатым сусликом неравномерно: наиболее заражёнными оказались Старобельский и восточная часть Купянского уездов до р. Оскол. Здесь количество жилых нор на десятине (1,09 га) доходило до 250, особенно в восточной части Старобельского уезда, в районе девственных степей, принадлежащих четырём государственным конным заводам. Остальная часть Харьковской губернии, начиная от р. Оскол и кончая крайними северо-западными уездами - Сумским и Лебединским, была населена сусликами гораздо реже, причём их количество на десятине не превышало здесь 10. Результаты наблюдений, кроме того, привели к выводу о возможных ежегодных миграциях сусликов с целины на поля и обратно, что обеспечивало выживание вида при недостатке корма, но наносило большой урон урожаю [Виноградов, 2005].

Ещё большая плотность крапчатого суслика была зафиксирована А.В. Ксенжопольским [1915] примерно в эти же годы на территории Шубковского Полигона в Ровенском уезде Волынской губернии, занимающего площадь в 10000 десятин казённой земли. Автор сообщает: «Как показали мои личные исследования в мае 2015 г., густота населения сусликов в Шубковском Полигоне прямо таки поразительная и, наблюдая их с одной 
только точки поля, мне приходилось насчитывать не менее 60 штук зверьков, одновременно появлявшихся вокруг моей персоны».

Простые расчёты автора дали внушительные результаты: «Считая, что на 3-х квадратных саженях там живёт только один суслик (что в сущности гораздо меньше действительности!), неизбежно приходим к выводу, что на 1 десятине (1,09 га) их водится не менее 800-1000 штук, а на всём пространстве Шубковского Полигона - вероятно около 810 млн. экземпляров. Цифра, как видно, внушительная и говорящая сама за себя!».

Утверждение это можно было бы посчитать ошибочным, если бы автор, рассеивая свои же сомнения, не привёл бы тут же подтверждающие факты: «В том, что расчёт наш относительно общего количества сусликов на Полигоне и в окрестностях его правилен и ничуть не преувеличен, убеждает ещё случай, имевший место в прошлом году на земле крестьянина Ивана Гойды из соседнего села Забороля, который, обладая в одном месте $1 / 2$ десятиной поля (0,6 га), в короткий промежуток времени, путём заливки водою нор, уничтожил на нём 372 зверька и всё-таки не добился полной очистки своего участка земли от вредителей» [Ксенжопольский, 1915, с. 27].

Такие непредвзятые данные более чем столетней давности представляют для реализации современных задач сохранения вида особую ценность, так как в наше время их уже невозможно ни перепроверить, ни реально смоделировать. И они дают достаточно убедительные ответы из реальной практики на дискуссию о допустимости высокой плотности создаваемых резервных популяций крапчатого суслика на ограниченной территории. И возможности здесь, как мы видим, могут быть довольно широкими.

Кроме этого, выяснение автором причин происхождения такой высокой численности сусликов на территории Полигона приводит нас ещё к одному важному выводу о необходимости и эффективности искусственного создания оптимальных условий для создаваемых резервных популяций вида. «По словам местных крестьян, массовое размножение сусликов в Ровенском уезде - явление сравнительно недавнее и наблюдается не более 18-20 лет, главным образом с момента превращения тамошних пахотных земель в необрабатываемый плугом участок военного полигона, что и дало возможность грызунам беспрепятственно устраивать свои норы. До этого факта суслики, хотя и встречались, но довольно редко и заметного вреда местным хозяйствам никогда не причиняли» [Ксенжопольский, 1915, с. 27-28].

В начале 30-х годов XX века при изучении степени вреда сельскому хозяйству от конкретных видов млекопитающих указывалось, что «в Центрально-Черноземной области, в особенности в южных её районах, крупным вредителем зерновых культур является крапчатый суслик». Этот же вид был назван первым из семи видов сусликов в списке вредителей зерновых культур на равнинах [Виноградов, Оболенский, 1932, с. 140].

В весенне-летний период 1935 и 1936 гг. на западе Белгородской области, в заповеднике «Лес на Ворскле» А.К. Крень с группой студентов проводила изучение фауны позвоночных животных. И хотя работы в основном проводились на территории лесного массива, а не на открытых участках его окрестностей, первым в списке млекопитающих отмечен крапчатый суслик - Citellus suslicus suslicus Güld. Автор пишет: «Стационарных работ в культурном ландшафте и в степных балках не проводилось, поэтому нельзя точно определить ни численность этого вида, ни характер его распространения. Всё же очевидно, что крапчатый суслик - обычный вид в данном районе. В 1936 г. крапчатый суслик (совершенно целый) найден в гнезде чёрного коршуна. Имеется также экземпляр этого суслика в музее заповедника» [Крень, 1939, с. 201].

В середине XX в. экспедициями И.И. Барабаш-Никифорова, изучавшего териофауну Воронежской области, была охвачена и восточная часть Белгородской области. Исследования 1951-1954 гг. показали, что в центральной части Алексеевского района наблюдалась относительно высокая плотность популяции крапчатого суслика - свыше 50 жилых нор на 1 га при среднегодовой добыче более 400 зверьков на 1000 га. Севернее и южнее 
этого очага отмечалась средняя плотность вида - от 20,1 до 50 жилых нор на 1000 га при среднегодовой добыче от 150,1 до 400 особей на 1000 га. И только территория Ровеньского района отличалась низкой плотностью популяции - до 20 жилых нор на 1 га при среднегодовой добыче до 150 зверьков на 1000 га [Барабаш-Никифоров, 1957].

В это же время в Борисовском районе П.К. Смирновым проводилось изучение суточной активности крапчатого суслика, имеющей тогда определённое значение в эпизоотологических процессах. Учёным сообщается, что материалом послужили наблюдения с помощью актографа за 20 зверьками, отловленными в июне - августе 1951 г., а также визуальные наблюдения в течение летних сезонов 1950-1952 гг. В результате была установлена зависимость сезонного перехода от состояния активности к спячке от сочетания двух основных факторов: содержания влаги в корме и температуры местообитания. Оказалось, что высушенный корм вызывает спячку у сусликов при температуре ниже $+22^{\circ}$ [Смирнов, 1964].

Полученные данные ценны в плане зоокультуры тем, что указывают на возможность продления нажировки зверьков в резервных полувольных популяциях всего лишь регулярным обеспечением их сочными кормами. Это должно позволить им хорошо подготовиться к спячке, успешно перезимовать и весной более массово вступить в размножение, что и требуется от специально сохраняемых популяций.

Суслики были обычны в Борисовском районе и позже, в конце 60-х годов, что подтверждается работами О.В. Петрова по изучению фауны млекопитающих учлесхоза «Лес на Ворскле» и его окрестностей. Так, для изучения стациального распределения крапчатого суслика - Citellus (Citellus) suslicus Güld. было отловлено 93 особи, у 81 зверька изучено содержимое пищеварительного тракта, что свидетельствует о доступности вида в то время и возможности получения от него массового научного материала. В числе освоенных видом местообитаний называлось более 10 стаций, из которых в наибольшем количестве суслики водились на залежах и по балкам.

Немалый интерес представляют факты, касающиеся размножения вида. Здесь автор, ссылаясь на П.К. Смирнова, сообщает о добыче им двух беременных самок. Первая, с эмбрионами 9 мм, была поймана 17 апреля 1950 г., что соответствует обычным срокам размножения. Вторая же, с эмбрионами всего 4-5 мм, была отловлена уже летом, 19 июня 1950 г., что, по мнению автора, может указывать на «заметно растянутый» период размножения вида в окрестностях учлесхоза [Петров, 1971]. Не исключено, что более ранние утверждения некоторых исследователей о том, что суслики «размножаются дважды в лето» [Горбачёв, 1925, с. 451], были основаны в то время именно на таких случаях запоздалого размножения отдельных особей. Возможно, что поздняя беременность характерна для самок поздних выводков прошлого года рождения, которые выходят из спячки с малым весом и вступают в размножение только после набора необходимого веса.

После работ Петрова О.В. специальных исследований по суслику на территории Белгородской области больше не было. В эти годы комплексные ежегодные наблюдения проводились сотрудниками Центрально-Черноземного заповедника на степных участках Ямская Степь и Лысые Горы, образованных в Губкинском районе в 1935 и в 1993 гг., в местах давнего обитания сусликов. 29 марта 1999 г. эти участки были переданы заповеднику «Лес на Ворскле» в Борисовском районе, получившему новое название - «Белогорье». Его сотрудниками были продолжены здесь дальнейшие наблюдения.

Находки поселений сусликов в регионе всё больше стали носить случайный характер, причём сведения о них нередко доходили до зоологов с большим опозданием, когда колонии уже прекращали своё существование. Так, по сообщению доцента кафедры зоологии и паразитологии Воронежского университета А.С. Климова, примерно в 2010 году суслики появились на кладбище г. Старый Оскол в с. Каплино. Причём проникли они довольно далеко вглубь кладбища, освоив под колонию территорию захоронений 1990-х годов, ещё не очень заросшую деревьями. Старая часть кладбища (1980-е гг.) к тому време- 
ни уже сильно заросла, что, возможно, воспрепятствовало дальнейшему продвижению вида. Проникновение сусликов, вероятно, происходило с соседних залежных участков, расположенных севернее, которые в то время тоже начали использоваться под захоронения. Колония была относительно небольшая, зверьки встречались на площади примерно 0,30,5 га. Однако жили они здесь недолго, не более двух лет. Скорее всего, они мешали людям своей роющей деятельностью и те их потравили (А.С. Климов, личное сообщение).

В начале XXI в. изучением динамики численности малого и крапчатого сусликов на территории Харьковской области обстоятельно занимался В.А. Токарский. Учёным широко использовались архивные документы, литературные источники и данные государственных станций защиты растений (за период с 1933 по 2010 гг.). В итоге было установлено, что на протяжении двух веков численность сусликов изменялась несколько раз. Периоды её высоких значений не превышали трёх десятков лет каждый (конец XVIII в., середина XIX в., 1880-1900 гг., 1920-1950 гг.) [Токарский, 2013].

Однако последние 70 лет в России и в целом по ареалу наблюдается неуклонное падение численности крапчатого суслика вплоть до полного его исчезновения из фауны многих регионов. В этой связи никаких оснований для надежды на очередную вспышку численности уже нет и не может быть по причине почти полного отсутствия крупных маточных колоний. В целом по Украине численность крапчатого суслика в последние годы упала в тысячи раз. На начало XXI века в стране осталось не более тысячи взрослых особей в нескольких колониях [Межжерин, 2009]. При этом численность вида в Харьковской области на момент подготовки Красной книги не была определена [Токарский, 2013а].

В последние годы на сопредельной с Белгородской областью территории Украины изредка всё же случаются находки сусликов. Так, в 2016-2017 гг. наблюдалась колония крапчатого суслика в остепнённой балке у западной околицы с. Братеница Великописаревского района Сумской области. К сожалению, размеры колонии и численность в ней особей не указаны [Скляр и др., 2018].

Как чрезвычайно редкий вид суслик крапчатый, возможно, ещё сохранился на востоке Украины в Луганской области. Здесь до 2012 гг. обнаружена всего одна колония с весенней численностью не более 10 особей [Русин, 2013]. Однако согласно более поздней публикации при обследовании авторами 169 природно-заповедных территорий, образованных в Луганской области к 2016 году, крапчатый суслик был отмечен в пяти из них [Евсюкова, Форощук, 2016]. При этом численность колоний также не указана.

Исключительную редкость в масштабах государств и всего ареала вида представляют случаи, когда обнаруживаются очень крупные по нынешним временам поселения крапчатого суслика. Так, у с. Суховоля Бродовского района Львовской области 16 апреля 2013 г. по данным А.П. Мандзя и М.В. Ковальчук была найдена колония численностью более 1000 особей, занимающая площадь более 50 га [Баточенко, 2018].

Необходимо отметить, что результатами генетических исследований доказано обитание на правобережье Днепра западной светлоокрашенной формы крапчатого суслика с диплоидным числом хромосом $2 \mathrm{n}=36$ (Spermophilus suslicus odessanus Nordmann 1840), a на левом берегу - восточной формы с более тёмной окраской, яркой пятнистостью и диплоидным набором хромосом $2 \mathrm{n}=34$ [Загороднюк, Федорченко, 1995]. Хотелось бы надеяться, что обнаруженная «львовская» колония, принадлежащая к западной форме, будет сохранена и в дальнейшем сможет рассматриваться как донорская для восстановления её ареала на территории западной части Украины. Однако дальнейших публикаций по судьбе вышеуказанной колонии нами не обнаружено.

В целом же ситуация с выживанием крапчатого суслика на Украине в последнее время близка к критической. Обследование территории страны в 2005-2012 гг. показало, что этот вид сохранился лишь в Старобельских степях, а его численность составляет всего 0,03-0,51\% от уровня середины XX века [Русин, 2013]. Чуть раньше учёный уже преду- 
преждал, что «в сложившихся условиях при сохранении современных тенденций природопользования вымирание сусликов на Украине неизбежно» [Русин, 2011, с. 13].

В Белгородской области последняя встреча крапчатого суслика зафиксирована в 2003 г. в охранной зоне участка Ямская Степь ГПЗ «Белогорье». Отмечается также, что в последние 15 лет достоверных сведений об обнаружении вида не территории области не регистрировалось [Шаповалов, Присный, 2005; Шаповалов, 2019].

\section{Брянская область}

В числе позвоночных животных бывшей Орловской губернии, куда ранее входил и Брянский уезд, С.Н. Горбачёв описывает и крапчатого суслика - Spermophilus guttatus, «По местному свистунок» [Горбачёв, 1925, с. 451]. Он тут же отмечает, что «другой вид, серый суслик, в губернии пока не найден». Такая осведомлённость автора в вопросах систематики рода сусликов логично объясняется масштабами вреда, причиняемого этими зверьками в то время сельскому хозяйству. Он пишет: «Наряду с серой полёвкой суслик является страшным бичём земледелия, уничтожая иногда на корню целиком весь урожай». При этом он ссылается на выписку из центральной печати об опасной ситуации в сельском хозяйстве Украины, где расплодившиеся суслики в массе пошли на поля, грозя уничтожить весь урожай. Автор приводит цифры из сводок по заражению зверьками площадей в сотни тысяч десятин, по затравке жилых нор под два миллиона, по истреблению самих сусликов свыше трёх миллионов в год на территориях некоторых южных губерний.

На этом фоне цифры, приводимые им ниже по Орловской губернии, выглядят уже не так устрашающе. Автор пишет: «В 1923 году суслики в Орловской губернии дали себя почувствовать настолько, что местной Станции Защиты растений пришлось затратить в июне около 230 руб. золот. на затравливание сусликов в районе села Сабурова. Затравлено было около 400 нор». Распределение вида по губернии в границах того времени было также довольно обширным: «Суслик очень часто встречается в уездах Елецком, Ливенском, Малоархангельском и Орловском. В окрестностях Орла многочислен по староКромскому большаку, у села Сабурова, Лаврова, - по Новосильскому большаку, где особенно много близ села Собакина, - много по Наугорскому тракту и в окрестностях села Муратова, Волховского уезда» [Горбачёв, 1925, с. 451-452].

Из описания С.Н. Горбачёвым биологии вида явно ошибочным является лишь утверждение автора о повторных выводках суслика - «размножается дважды в лето». Поводом для формирования такого мнения могли стать как масштабные вспышки численности сусликов по стране, так и факты встреч самок на ранних сроках беременности в конце второй декады июня [Петров, 1971]. Такие отклонения, возможно, замечались и чаще, но оставались неизвестными науке, поэтому поначалу могли вызвать подобные заблуждения.

Г.Л. Граве в своей книге об охотничьей фауне региона при упоминании о суслике ссылается на результаты работ В.А. Меландера, который, «исследуя грызунов юга Западной области, нашёл близ с. Комаричей довольно большую колонию крапчатого суслика». Подчёркивая обилие в ней зверьков, Г.Л. Граве пишет: «В течение часа ему удалось поймать 17 экземпляров. Их норки находились на луговинах, расчищенных из-под леса. Интересно, что местное население совершенно не знало о существовании по соседству этого зверька. Другое место, где суслики встречаются в заметном количестве, находится близ с. Угревичи и под Севском. На север отсюда этот зверёк становится более редким. Под Почепом и Карачевым ещё встречается, но не часто». Оценивая народнохозяйственное значение вида в Западной области, автор пишет: «Суслик, благодаря своей малочисленности, в области практического значения не имеет. На заготовительные пункты попадает в год несколько десятков шкурок, которые смешиваются с "прочей пушниной"» [Граве, 1933, с. 64].

При определении границы ареала вида в регионе Г.Л. Граве так же руководствуется мнением В.А. Меландера: «В общем, В.А. Меландер считает, что северная граница рас- 
пространения суслика идёт от Погар на Почеп и, не доходя до Брянска, сворачивает на Карачев». Чуть позже появились дополнительные сведения о находках вида в Севском, Брасовском, Комаричском, Брянском, Навлинском и бывшем Хотынецком районах [Mеландер и др., 1935]. Позже было установлено, что в регионе северо-западная граница ареала, проходя по Оке через Коломну и Каширу, резко опускается от Серпухова к югу, по направлению к Орлу, и тянется дальше между Карачевым и Брянском на Почеп, к северной части б. Черниговской губернии [Огнев, 1947].

Снижение численности крапчатого суслика во второй половине XX века по всей стране особенно заметно проявилось на границе ареала. Поиски вида в Брянской области в последние десятилетия XX века не принесли успеха и суслику в первом издании региональной Красной книги была присвоена категория 0 - «вероятно исчезнувший вид» [Мишта, 2004; Ситникова, Мишта, 2006].

Однако в 2015 г. неожиданно была обнаружена колония крапчатого суслика в Карачевском районе у д. Аксиньина, причём выяснилось, что она существует здесь с 1998 г. [Ситникова, 2016]. Сохранилась эта колония благодаря своему расположению на территории нефтеперекачивающей станции (НПС «Аксинино»), принадлежащей АО «Транснефть-Дружба». Вся площадь станции составляет 16 га, на ней возведены административное и бытовые здания, посажены яблони, оборудованы естественные газоны. В соответствии с производственными требованиями на всех станциях «Транснефти» регулярно скашивается и вывозится подрастающая трава, что создаёт для сусликов необходимый биотоп пастбищного типа. Наличие сада позволяет зверькам дополнять свою пищу яблоками, а плотный грунт - устраивать надёжные и долговечные норы. Хищники сюда тоже, как правило, почти не проникают. Налицо все основные условия оптимальной среды обитания, что и было отмечено в прессе [Калмацкий, 2016]. Весной 2016 г. здесь были проведены комплексные исследования колонии с живоотловом 19 особей и выпуском их обратно, включая изучение морфологических особенностей данной популяции [Проявка и др., 2017]. Несомненно, данную колонию можно рассматривать как один из немногих реальных вариантов сохранения крапчатого суслика в условиях агро-селитебных стаций селитебных экосистем [Демянчик, Никифоров, 2017].

\section{Белоруссия}

Крапчатый суслик в Белоруссии в XX веке был распространён на изолированном участке общего ареала вида, размещённом в лесной зоне [Петровский, 1961]. За период исследований с 1948 по 1955 гг. очаги вида были выявлены в 13 районах Республики. Наиболее плотно оказались заселены Новомышский, Мирский, Копыльский, Несвижский и Ляховичский районы, в которых было расположено 58 очагов общей площадью 16450 га. Плотность нор сусликов составляла в среднем 108 на 1 га [Петровский, 1960].

По мнению Е.В. Яцентковского (1924), в начале XIX в. суслики были завезены сюда князем Радзивиллом, владельцем б. имений Тимкевичи и Несвижа. Зверьки сильно размножились и встречались в б. волостях: Вызнянской, Киевической, Потейковской, Телядовической; на юг доходили до Слуцка [Яцентковский, 1924; цит. по: Огнев, 1947]. Однако другие исследователи признают естественное образование ареала. Отсутствие в литературе достоверных фактов, свидетельствующих о привозе сусликов, особенности географического положения ареала в Белоруссии на возвышенностях, ограничивающих Полесскую низменность на севере, наличие в прошлом на территории Республики степных пространств, наконец, находки остатков сусликов на юге и юго-западе Полесской низменности - все эти факты говорят в пользу мнения о естественном происхождении ареала суслика в Белоруссии [Петровский, 1960].

Истребление сусликов в Республике власти начали организовывать ещё в начале 20-х годов XX века. Такая работа в эти годы проводилась Станцией по борьбе с вредителями организованными бригадами крестьян посредством затравки нор сероуглеродом. 
В 1924 г. этим методом по приблизительному подсчету была очищена площадь около 200000 десятин (218 000 га) и истрачено 1440 кл. (1 440000 л) сероуглерода [Яцентковский, 1927].

В середине XX века крапчатый суслик в Белоруссии был ещё довольно многочисленным, что позволило отловить в 1954 и 1955 гг. для специальных исследований 814 экз. В это время продолжались работы как по изучению экологии сусликов, так и по научному обеспечению их истребления, включая избирательность ими отравленных приманок [Петровский, 1961]. Тогда же для борьбы с сусликом применяли даже боевые отравляющие вещества: в 1951 г. в основных поселениях было затравлено хлорпикрином около 2 млн норок. Огромные потери население сусликов в Белоруссии потерпело в конце 1960-х - начале 1970-х гг., после применения в качестве средства борьбы аммиачной воды. По приблизительной оценке, численность крапчатого суслика в Беларуси с 1960-го года на начало XXI века снизилась на 80-90 \% [Демянчик, 2006].

В 2010-2011 годах в рамках реализации одного из природоохранных проектов ПРООН-ГЭФ на территории Кореличского района Гродненской области Республики Беларусь были выявлены 3 колонии крапчатого суслика. Колонии располагались на заброшенном пастбище и пустыре в окрестностях посёлка Мир, а также на участке придорожной полосы автомобильной дороги Мир - Новогрудок у д. Рапьево (вблизи д. Турец). Численность сусликов в колониях составляла от единичных особей до 20-25 зверьков. Предполагалось, что соблюдение разработанных авторами требований по охране выявленных мест обитания и реализация рекомендованных мероприятий позволит сохранить этот вид в Кореличском районе на протяжении ближайших 10-15 лет [Шакун, Максименков, 2013]. Однако уже через два года придорожная колония была распахана [Комягина, 2013; Популяция ..., 2013], а весной 2019 г. сусликов в Кореличском районе вообще не удалось найти [Шокало, 2019].

В весенне-летние периоды 2018-2020 гг. были проведены специальные поиски суслика в Барановичском, Кореличском, Столбцовском, Ляховичском, Несвижском, Новогрудском, Клецком, Копыльском и Узденском районах. В ходе обследования свыше 200 предполагаемых местообитаний вида было выявлено всего двенадцать локальных группировок суслика с численностью от одиночных животных до нескольких тысяч особей. Однако уже в 2020 году четыре самых малочисленных колонии прекратили своё существование и ещё четыре оказались на грани исчезновения. Из шести оставшихся колоний надежду на выживание вида в Беларуси вселяют только две самых крупных в Несвижском районе: у деревни Юшевичи (около 10-11 тыс. нор) и у деревни Сейловичи, примерно в 5 км от первой (около 150 используемых нор) [Шокало, Янкевич, 2020].

Основные причины исчезновения последних колоний - повсеместная распашка и дискование бывших выпасов (включая распашку территории даже заброшенного пионерского лагеря) и высокий пресс хищничества (особенно лисицы и домашней кошки) [Шокало, 2019; Шокало, Янкевич, 2020].

\section{Заключение}

Обзор публикаций по крапчатому суслику в Центральном Черноземье и сопредельных областях показал, что катастрофическое сокращение численности вида в этом регионе шло похожими путями. В целом за последние века крапчатый суслик прошёл здесь два основных периода: 1) неуправляемую вспышку численности на прогонных пастбищах, образованных человеком, и 2) масштабную гибель в ходе истребительных мероприятий, организованных тоже человеком. В дальнейшем, под воздействием набора других «добивающих» факторов, включая и «человеческий», это привело вид в регионах к его полному или почти полному исчезновению. В конечном итоге исключительно редкие случаи сохранения остатков популяций суслика стали регистрироваться не в условиях естественной природной среды, а на антропогенно трансформированных территориях - на спортивном 
аэродроме (бывшем колхозном) (г. Усмань Липецкой обл.), на нефтеперекачивающей станции (Карачевский р-н Брянской обл.), на обочинах автодороги «Каспий» (Никифоровский р-н Тамбовской обл.), на городских кладбищах (г. Липецк, г. Старый Оскол). Но даже эти последние «островки выживания» находятся в зоне большого риска, что подтверждается вольным или невольным уничтожением людьми и этих последних поселений сусликов (усманский аэродром, тамбовская автотрасса, старооскольское кладбище).

Нет никаких гарантий и на спасение колоний сусликов, сохранившихся в типичных условиях «советских» пастбищ, сохранившихся вместе с сусликами со времён СССР (Республика Беларусь), так как крупный рогатый скот постепенно переводится здесь на стойловое содержание, а бывшие выпасы повсеместно распахиваются. При этом, как свидетельствуют последние посты учёных-энтузиастов в соцсетях, ни Красная книга, ни готовый пакет необходимых документов эти местообитания в реальности не защищают. В итоге, как правило, требование охраны видосберегающих стаций приводит лишь к конфликту с землепользователями, за который в конечном итоге расплачиваются сами суслики. Назрела острая необходимость разработки и внедрения в практику принципиально новых, неконфликтных методов спасения вида, его разведения и последующего восстановления в подходящих местообитаниях.

В предыдущих наших работах предлагалось рассматривать крапчатого суслика как синантропный вид, который больше не в состоянии самостоятельно сохраниться и восстановиться в условиях «дикой» природной среды. Предлагались варианты его спасения путём полувольного вольерного разведения на базе степных ООПТ или зоопарков, то есть создания его видовых питомников, но это требует определённых материальных затрат уже на первом этапе проекта при искусственном обеспечении виду оптимальной среды обитания и условий, исключающих воздействие хищников. Однако в условиях государственного финансового дефицита это уже изначально усложняет процедуру обсуждения и первичного согласования проекта с руководством всех уровней, что быстро обесценивает и отметает его как излишне затратный.

С учётом вышеуказанных обстоятельств предлагается потенциально неконфликтный и относительно дешёвый путь сохранения и разведения крапчатого суслика, причём по-прежнему на основе его восприятия как синантропного вида. В связи с достаточно быстрым его привыканием к присутствию человека, возможно, одним из реальных путей сохранения вида могло бы стать создание его резервных популяций не вдали от людей, a, наоборот, рядом с ними, в местах массового посещения людьми природных и иных объектов. В этом случае необходимо подобрать максимально подходящую для вида территорию, расположенную в оптимуме его ареала. Место это должно быть недоступно для кошек и собак. Лучше, если оно будет находиться вдали от населённых пунктов. Диких же хищников будут отпугивать сами люди своим присутствием. Для защиты от нападения пернатых хищников над скоплениями нор должна быть натянута крупноячеистая металлическая сетка из тонкой проволоки. В дальнейшем этот минимум условий может быть расширен в рабочем порядке, согласно появляющимся новым обстоятельствам.

Вышеуказанным условиям предположительно могут удовлетворять некоторые региональные природные парки, базы отдыха, санатории, сафари-парки, семейные парки и другие территории, где в весенне-летнее время на природе постоянно присутствуют люди, но отсутствуют дикие и домашние хищники. Возможность создания резервных популяций крапчатого суслика на базе территорий, практически готовых к выпуску зверьков, могло бы сильно облегчить организацию такого проекта и заметно способствовать сохранению и восстановлению вида в границах его исторического ареала.

Признание природоохранными структурами всех уровней того, что крапчатый суслик в России сегодня так же, как когда-то странствующий голубь в Америке, находится у «последней черты» и может навсегда исчезнуть из фауны Земли, возможно, ещё сможет изменить ситуацию в лучшую сторону и спасти вид. 
В прочессе подготовки статьи авторы столкнулись с необходимостью поиска недостающих литературных источников (особенно прошлых веков) и обратились за помощью к коллегам. Авторы искренне благодарят д.б.н. В.А. Лобкова, проф. В.П. Белика, проф. Г.А. Ладу, дочента ТГУ А.С. Соколова, к.б.н. Е.Ф. Ситникову, к.б.н. А.С. Климова, к.б.н. И.Э. Мазурову, д.б.н. И.В. Загороднюка (сайт специальной литературы), директора ГПЗ «Белогорье» А.С. Шаповалова, директора ЦЧЗ, к.б.н. А.А. Власова, с.н.с. ХГЗ. Н.Ф. Марченко, с.н.с. ХГЗ, к.б.н. Е.В. Печенюк, зоологу С.И. Шокало за оказанную помощь в поиске и подборе литературы.

\section{Список литературы}

1. Александров Д.Ю., Иванова А.Д., Титов С.В., Ермаков О.А. 2019. Находка жёлтого суслика (Spermophilus fulvus) в Чёрных землях Калмыкии и другие случаи интродукции сусликов. $B$ кн.: Млекопитающие России: фаунистика и вопросы териогеографии. Материалы конференции (Ростов-на-Дону, 17-19 апреля 2019 г.). М., Товарищество научных изданий КМК: 8-10.

2. Александров В.Н., Недосекин В.Ю. 1998. Наземные позвоночные животные Лесостепной опытно-селекционной станции и её окрестностей. $B$ кн.: Вопросы естествознания. Вып. 6. Липецк: 57.

3. Асоскова Н.И., Херувимов В.Д. 1966. Изменения в охотничье-промысловой фауне. $B$ кн.: Атлас Тамбовской области. М., $11 \mathrm{c.}$

4. Барабаш-Никифоров И.И. 1957. Крапчатый суслик - Citellus suslica Güld. B кн.: Звери юго-восточной части Черноземного центра. Воронеж: 219-232.

5. Барабаш-Никифоров И.И., Павловский Н.К. 1948. Фауна наземных позвоночных Воронежского государственного заповедника. $B$ кн.: Труды Воронежского государственного заповедника. Вып. 2. Воронеж, 7-128.

6. Баточенко В.М. 2018. Реєстрації деяких видів фауни занесених до Червоної книги України на Волино-Поділлі. В кн.: Серія: «Conservation Biology in Ukraine». Вип. 7, Т. 1. Матеріали до 4-го видання Червоної книги України. Тваринний світ. Київ: 22-23.

7. Белик В.П. 2011. Крапчатый суслик в Ростовской области: фантом или реальность? В кн.: Проблемы Красных книг и преподавание охраны природы. Ростов-на-Дону: 105-108.

8. Беляченко А.В. 2006. Суслик крапчатый - Spermophilus suslicus (Guldenstaedt, 1770). $B$ кн.: Красная книга Саратовской области. Грибы. Лишайники. Растения. Животные. Саратов, Изд-во Торгово-промышленной палаты Саратовской области: 483-485.

9. Брандлер О.В., Власова О.П., Власов Е.А. 2012. Реинтродукция степного сурка в Центрально-Черноземом заповеднике. Степной бюллетень, 35: 50-55.

10. Будниченко А.С., Рымашевский В.К., Скопцов А.Г., Строков В.В. 1964. Определитель позвоночных животных Тамбовской области. Воронеж, Центрально-Черноземное книжное изд-во, 120 с.

11. Быстракова Н.В., Ермаков О.А., Титов С.В. 2005. Хромосомный маршрут на Среднем Дону. Вестник ВОГИС, 9 (1): 67-69.

12. Виноградов Б.С. 2005. Биологическия наблюдения над крапчатым сусликом (Spermophilus guttatus Temm.) (Печатается с сокращениями по оттиску 1914 г). Известия Музейного фонда им. А.А. Браунера, II (2): 15-16.

13. Виноградов Б.С., Аргипуло А.И. 1941. Фауна СССР. Млекопитающие. Определитель грызунов. М.-Л., Изд-во АН СССР: 243.

14. Виноградов Б.С., Оболенский С.И. 1932. Вредные и полезные в сельском хозяйстве млекопитающие. М.-Л., Госуд. изд-во сельскохоз. и колхозно-кооперат. литературы, 222 с.

15. Власов А., Брандлер О. 2011. Крапчатый суслик исчез в Курской области? Степной бюллетень, 33: 35.

16. Власов А.А. 125 лет со дня рождения Е.С. Птушенко. Новость на сайте ЦЧЗ от 24.01.2013 г. URL: http:zapoved-kursk.rupress-centrnovosti125-let-so-dnya-rozhdeniya-e-s-ptushenko. html (дата обращения: 28 января 2021).

17. Власов А.А. 1995. Современное состояние популяций степных видов млекопитающих Центрально-Черноземного заповедника и перспективы их дальнейшего существования. $B$ кн.: Проблемы сохранения разнообразия природы степных и лесостепных регионов. Материалы 
Российско-Украинской научной конференции, посвящённой 60-летию Центрально-Черноземного заповедника. М., КМК Scientific Press: 226-227.

18. Власов А.А. 2001. Изменение териофауны лесостепных заповедников. В кн.: Труды Ассоциации особо охраняемых природных территорий Центрального Черноземья России. Вып. 2. Зоологические исследования в заповедниках Центрального Черноземья. Тула: 5-13.

19. Власов А.А., Власова О.П. 2006. Позвоночные животные, рекомендуемые к занесению в Красную книгу Курской области. $B$ кн.: Исследования по Красной книге Курской области. Курск: 21-24.

20. Гмелин С.Г. 1806 (1771). Путешествие по России для исследования трёх царств естества. Ч. 1. Путешествие из Санктпетербурга до Черкаска, главного города Донских казаков в 1768 и 1769 годах. Пер. с нем. 2-е изд. Спб., Имп. Акад. Наук, 272 с. $411-463$.

21. Горбачёв С.Н. 1925. Позвоночные животные. $B$ кн.: Природа Орловского края. Орёл:

22. Граве Г.Л. 1933. Промысловые звери. В кн.: Охотничьи промыслы в Западной области. Смоленск, Запгиз: 44-79.

23. Данилов П.Н. 1868. Описание видов рукокрылых и насекомых, водящихся в юго-восточной части Орловской губернии, с естественно-историческим взглядом на местности, занимаемою Елецким уездом. [Соч.] П.Н. Данилова. Ксерокопия. М., Типография Селивановского, 32 с.

24. Демянчик В.T. 2006. Крапчатый суслик Citellus suslicus (Güldenstaedt, 1770), Spermophilus suslicus (Güldenstaedt, 1770). В кн.: Красная книга Республики Беларусь. URL: http:redbook.minpriroda.gov.byanimalsinfo.html?id=11 (дата обращения 11 марта 2019).

25. Демянчик, В.В., Никифоров М.Е. 2017. Синантропный экологический комплекс и структура населения позвоночных на селитебных территориях Белорусского Полесья. Весиі нацьяннальнай Акадэміі навук Беларусі. Серыя біялагічных навук, 3: 7-17.

26. Денисова И.С. 1996. Фауна мелких млекопитающих Казацкого участка ЦентральноЧерноземного заповедника. $B$ кн.: Фауна Центрального Черноземья и формирирование экологической культуры. Материалы конференции. Ч. 2. Липецк: 39-40.

27. Денисова И.С. 1997. Население мелких млекопитающих Казацкого участка Центрально-Черноземного заповедника и некоторые особенности его формирования. $B$ кн.: Многолетняя динамика природных процессов и биологическое разнообразие заповедных экосистем Центрального Черноземья и Алтая. Труды Центрально-Черноземного государственного заповедника. Вып. 15. М.: 171-180.

28. Добровольский О.П. 2013. Изменения в составе охотничьих млекопитающих Ростовской области в последние десятилетия: Автореф. дисс. ... канд. биол. наук. Ростов-на-Дону, $24 \mathrm{c}$.

29. ЕАРАЗА: информационные сборники 2005-2020. № 24-39. URL: http:earaza. ru?page_id=31 (дата обращения 8 декабря 2020).

30. Елисеева В.И. 1959. Список млекопитающих и птиц Центрально-Черноземного заповедника и некоторые данные по фенологии их миграций и размножения. $B$ кн.: Труды Центрально-Черноземного государственного заповедника. Вып. 5. Курск, Курское книжное издво: $377-418$.

31. Елисеева В.И. 1977. Фауна наземных позвоночных участка Баркаловка ЦентральноЧерноземного заповедника. $B$ кн.: Материалы к изучению природных экосистем Центральной лесостепи Русской равнины. Труды Центрально-Черноземного гос. заповедника. Вып. 8. Воронеж, Центрально-Черноземное книжное изд-во: 55-71.

32. Загороднюк I. 2006. Ссавці східних областей України: склад та історичні зміни фауни. В кн.: Праці Теріологічної школи, Теріофауна сходу України. Вип. 7. Луганськ: 217-259.

33. Загороднюк И.В., Федорченко А.А. 1995. Аллопатрические виды среди грызунов группы Spermophilus suslicus (Mammalia). Вестник зоологии, 5-6: 49-58.

34. Здешнева И.Э. 1992. Особенности ландшафтного распространения крапчатого суслика на востоке Среднерусской возвышенности. $B$ кн.: Чтения памяти профессора В.В. Станчинского. Смоленск: 89-93.

35. Зозулин Г.М. 1950. Стрелецкая степь. Курск, Изд-во «Курская правда», 71 с.

36. Ильяшенко В.Ю., Шаталкин А.И., Куваев А.В., Комендантов А.Ю., Бритаев Т.А., Косьян А.Р., Павлов Д.С., Шилин Н.И., Ананьева Н.Б., Туниев Б.С., Семёнов Д.В., Сыроечковский Е.Е., Морозов В.В., Мищенко А.Л., Рожнов В.В., Поярков А.Д. 2018. Редкие и находящиеся под угрозой исчезновения животные России. Материалы к Красной книге Российской Федерации. М., Товарищество научных изданий КМК, 69 с. 
37. Калмацкий М. 2016. Кто свистит на НПС? Трубопроводный транспорт нефти, 9: 6871. URL: https://www.transneft.ru/u/eco_publish_file/132/sysliki.pdf (дата обращения: 9 февраля 2021).

38. Климов А.С. 2018. Суслик крапчатый Spermophilus suslicus (Güldenstaedt, 1770). B кн.: Красная книга Воронежской области. Том 2. Животные. Воронеж, Центр духовного возрождения Черноземного края, $417 \mathrm{c}$.

39. Климов С.М. 2010. Материалы по фауне наземных позвоночных заповедника «Галичья гора» и его окрестностей. $B$ кн.: Экологические исследования в заповеднике «Галичья гора». Вып. 2. Воронеж, Издательско-полиграфический центр Воронежского государственного университета: 69-82.

40. Климов С.М., Александров В.Н. 1993. Животный мир Липецка и его охрана. В кн.: Природа Липецкой области и её охрана. Вып. 7. Воронеж: 69-79.

41. Климов С.М., Сарычев В.С., Кузнецова В.Т. 1994. Состояние животного мира и задачи дальнейших исследований. $B$ кн.: Современное состояние растительного и животного мира Липецкой области и проблемы их охраны. Ч. 2. Липецк: 5.

42. Комягина О. 2013. В Кореличском районе распахали место обитания редкого вида суслика. Комсомольская правда - Беларусь. 10.07.2013. URL: https:www.kp.bydaily261053000893 (дата обращения 20 мая 2021).

43. Константинов В.М., Климов С.М., Хохлов А.Н. 1996. Синантропизация и урбанизация позвоночных животных Европейского Центра России. $B$ кн.: Фауна Центрального Черноземья и формирование экологической культуры. Материалы Первой региональной конференции (Липецк, 23-26 октября 1996 г.). Ч. 1. Липецк: 4-8.

44. Королькова Г.Е. 1975. Наземные позвоночные животные Теллермановского леса и их функциональная роль в биогеоценозах лесостепных дубрав. $B$ кн.: Дубравы лесостепи в биоценологическом освещении. М., Наука: 229-254.

45. Косырёвское кладбище (старое). Энциклопедия. Липецк и область. 16.10.2019. URL: https://xn----8sbnlbgcddd9bs6e.xn--p1ai/wiki/k/5298/ (дата обращения 31 мая 2021).

46. Красная книга Курской области. 2002. Том 1. Редкие и исчезающие виды животных. Тула, $120 \mathrm{c}$.

47. Крень А.Г. 1939. Позвоночные животные заповедника «Лес на Ворскле». Ученые записки ЛГУ. Серия биологических наук, 28 (7): 184-206.

48. Ксенжопольский А.В. 1915. Заметка о волынских сусликах и некоторых других животных из породы грызунов. Мышиная напасть на Волыни в 1913-1914 годах. Житомир, 25-42.

49. Лавров Л.С., Дьяков Ю.В., Никитин Н.М. 1992. Млекопитающие. В кн.: Флора и фауна заповедников СССР. Позвоночные животные Воронежского заповедника (Аннотированный список видов). М.: 32-40.

50. Литвинова С.С., Пиванова С.В., Шубина Ю.Э. 2009. Трофические связи крапчатого суслика в природно-антропогенном ландшафте. $B$ кн.: Роль естественных наук в решении проблем современного общества. Материалы Всероссийской студенческой конференции. Липецк: 70-72.

51. Марченко Н.Ф. 1996. Динамика видового разнообразия териофауны Хопёрского заповедника и окружающих ландшафтов. $B$ кн.: Фауна Центрального Черноземья и формирование экологической культуры. Материалы конференции. Ч. 2. Липецк: 49-51.

52. Марченко Н.Ф. 2003. Исчезновение крапчатого суслика Citellus suslicus в окрестностях Хопёрского заповедника. $B$ кн.: Териофауна России и сопредельных территорий - VII съезд Териологического общества. Материалы Международного совещания (Москва, 6-7 февраля 2003 г.). Москва: 215.

53. Марченко Н.Ф. 2016. Млекопитающие Хопёрского заповедника. Повидовой обзор. Отряд Rodentia, Bowdich, 1821 - Грызуны. $B$ кн.: Труды Хопёрского государственного заповедника. Вып. 10. Воронеж, Издательско-полиграфический центр «Научная книга»: 82-153.

54. Марченко Н.Ф., Печенюк А.Д. 2000. Материалы к кадастру териофауны ЦЧР (Новохопёрский район Воронежской области) за период с 1951 по 2000 гг. $B$ кн.: Экологофаунистические исследования в Центральном Черноземье и сопредельных территориях. Липецк, ЛГПУ: $168-171$.

55. Межжерин С.В. 2009. Суслик крапчатый Spermophilus suslicus (Güldenstaedt, 1770). $B$ кн.: Красная книга Украины. Животные. URL: http:redbook-ua.orgruitemspermophilus-suslicusgueldenstaedt (дата обращения 7 февраля 2018).

56. Миноранский В.А., Сидельников В.В., Симонович Е.И. 2015. Состояние популяций сусликов (Spermophilus sp.) на Дону. Фундаментальные исследования, 2-2: 277-280. 
57. Мишта А.В. Крапчатый суслик Spermophilus suslicus Guldenstaedt, 1770. В кн.: Красная книга Брянской области. Животные. Брянск, ЗАО «Изд-во «Читай-город»: 44-45.

58. Недосекин В.Ю. 2007. Современное состояние крапчатого суслика на севере Среднерусской возвышенности. $B$ кн.: Экологические исследования в заповеднике «Галичья гора». Вып. 1. Воронеж, Воронежский государственный университет: 133-135.

59. Недосекин В.Ю. 2009. Крапчатый суслик Spermophilus suslicus Guldenstaedt, 1770. $B$ кн.: Позвоночные Липецкой области. Кадастр. Воронеж, Издательско-полиграфический центр Воронежского государственного университета: 399-400.

60. Недосекин В.Ю. 2014. Млекопитающие. В кн.: Природа Плющани. Воронеж, Издательство «Научная книга»: 243-253.

61. Недосекин В.Ю. 2016. Класс млекопитающие - Mammalia. В кн.: Позвоночные заповедника «Галичья гора». Воронеж, Издательский дом ВГУ: 144-165.

62. Недосекин В.Ю., Климов С.М., Сарычев В.С., Александров В.Н. 1996. Позвоночные животные Липецкой области и их охрана. Липецк, Изд-во ЛГПИ и ЛИУУ: 79.

63. Недосекин В.Ю., Ушаков М.В. 2005. О состоянии крапчатого суслика в Липецкой области. B кн.: Суслики Евразии (роды Spermophilus, Spermophilopsis): происхождение, систематика, экология, поведение, сохранение видового разнообразия. Материалы российской научной конференции (Москва, 16-17 ноября 2005 г.). М., Т-во научных изданий КМК: 65-66.

64. Огнев С.И. 1947. Звери СССР и прилежащих стран. Т. 5. Грызуны. М.-Л., Изд-во АН CCCP: $142-162$.

65. Огнев С.И., Воробъёв К.А. 1923. Фауна наземных позвоночных Воронежской губернии. М., Изд-во Наркомзема «Новая деревня», 254 с.

66. Павлинов И.Я., Крускоп С.В., Варшавский А.А., Борисенко А.В. 2002. Наземные звери России. М., КМК, 298 с.

67. Павлинов И.Я., Лисовский А.А. (ред.). 2012. Млекопитающие России: систематикогеографический справочник. М., Т-во науч. изд. КМК, 604 с. МГУ, $285 \mathrm{c}$.

68. Павлинов И.Я., Россолимо О.Л. 1987. Систематика млекопитающих СССР. М., Изд-во

69. Павлинов И.Я., Россолимо О.Л. 1998. Систематика млекопитающих СССР: дополнения. М., Изд-во МГУ, 190 с.

70. Павлова Е.А. 1951. Суслик. М., Заготиздат, 80.

71. Петровский Ю.Т. 1960. Биологические особенности крапчатого суслика в Белоруссии. Автореф. дис. ... канд. биол. наук. Минск, 18 с.

72. Петровский Ю.Т. 1961. Особенности экологии крапчатого суслика в Белоруссии. Зоологический журнал, 40 (5): 736-748.

73. Печенюк А.Д. 2005. Млекопитающие и птицы Новохопёрского района. $B$ кн.: Состояние особо охраняемых природных территорий Европейской части России. Сборник научных статей, посвящённый 70-летию Хопёрского заповедника. Воронеж, Изд-во Воронежского университета: 401-406.

74. Пиванова С.В. 2008. Отношение населения к крапчатому суслику (Citellus suslicus Güld.). B кн.: Актуальные проблемы естественных наук и их преподавания. Липецк, ЛГПУ: 232-234.

75. Пиванова С.В. 2008а. Сезонная активность крапчатого суслика (Citellus suslicus Güld., 1770) в природно-антропогенном ландшафте окрестностей г. Липецка. $B$ кн.: Проблемы экологии и экологической безопасности Центрального Черноземья Российской Федерации. Материалы ХII Международной научно-практической конференции (Липецк, 3 декабря 2008 г.). Липецк, ЛЭГИ: 46-47.

76. Пиванова С.В. 2009. Распространение крапчатого суслика (Citellus suslicus Güld., 1770) в Центральном Черноземье. $B$ кн.: Сборник научных трудов аспирантов и соискателей. Вып. 6 . Ч. ІІ. Липецк, ЛГПУ: 63-64.

77. Пиванова С.В. 2009а. Характер размещения нор крапчатого суслика в природноантропогенном ландшафте Липецкого района. $B$ кн.: Актуальные проблемы естественных наук и их преподавания. Липецк, ЛГПУ: 131-134.

78. Пиванова С.В. 2011. Характеристика поселения крапчатого суслика в Задонском районе Липецкой области. $B$ кн.: Актуальные проблемы экологии и природопользования. Сборник научных трудов. Вып. 13. Ч. 1. М., РУДН: 153-156.

79. Пиванова С.В., Шубина Ю.Э. 2009. Факторы, влияющие на численность крапчатого суслика (Spermophilus suslicus Güldenstaedt, 1770) в природно-антропогенных ландшафтах. В кн.: Управление численностью грызунов-вредителей (pest management) и проблемы сохранения 
биологического разнообразия. Материалы российской научно-практической конференции с международным участием (Москва, 17-18 ноября 2009 г.). Москва, ИПЭЭ РАН: 48-49.

80. Пиванова С.В., Шубина Ю.Э. 2009а. К вопросу о необходимости регуляции крапчатого суслика в условиях природно-антропогенных ландшафтов Липецкого района. $B$ кн.: Экологическая безопасность региона. Материалы Международной научно-практической конференции (Брянск, 29-30 октября 2009 г.). Брянск, Изд-во «Курсив»: 276-277.

81. Пиванова С.В., Шубина Ю.Э. 2010. Городское кладбище как место сохранения популяции крапчатого суслика. $B$ кн.: Видовые популяции и сообщества в антропогенно трансформированных ландшафтах: состояние и методы его диагностики. Материалы XI Международной научно-практической эколэкологической конференции (Белгород, 2025 сентября 2010 г.). Белгород, ИПЦ ПОЛИТЕРРА: 177-178.

82. Пиванова С.В., Шубина Ю.Э. 2010а. Размножение крапчатого суслика в пригородной зоне города Липецка. $B$ кн.: Первые Международные Беккеровские чтения (27-29 мая 2010 г.). Ч. 1. Волгоград: 495-496.

83. Пиванова С.В., Шубина Ю.Э. 2010б. Состояние популяции крапчатого суслика в природноантропогенном ландшафте городского кладбища и его окрестностей. $B$ кн.: Проблемы изучения и восстановления ландшафтов лесостепной зоны. Сборник научных статей. Тула: 268-270.

84. Плечова 3.Н., Димитриев А.В., Солдатов С.П. 2010. Суслик крапчатый - Spermophilus suslicus (Gueldenstaedt, 1770). В кн.: Красная книга Чувашской Республики. Т. 1. Ч. 2. Редкие и исчезающие виды животных. Чебоксары, ГУП «ИПК Чувашия»: 272-273.

85. Популяция «краснокнижного» зверька - на грани катастрофы. Служба информации «ЕвроБеларуси». 08.07.2013. URL: https:eurobelarus.infonewssociety20130708pod-mirom-raspahalikoloniyu-suslikov.html (дата обращения: 20 мая 2021).

86. Предтеченский С.А. 1928. О фауне наземных позвоночных Тамбовского края. Известия Тамбовского общества изучения природы и культуры местного края, 3: 3-31.

87. Приказ Министерства природных ресурсов и экологии Российской Федерации от 24.03.2020 г. № 162 «Об утверждении Перечня объектов животного мира, занесённых в Красную книгу Российской Федерации». URL: http:docs.cntd.rudocument564578614 (дата обращения: 17 ноября 2020).

88. Проявка С.В., Шубина Ю.Э., Савинецкая Л.Е., Шекарова О.Н. 2017. Морфологическая характеристика крапчатого суслика Spermophilus suslicus Центральной части европейской России. Известия выстих учебных заведений. Поволжский регион. Естественные науки, 2 (18): 3-10.

89. Птушенко Е.С. 1937. Материалы к познанию териологической фауны Курского края. В кн.: Сборник памяти академика М.А. Мензбира. М.-Л., Изд-во АН СССР: 409-501.

90. Птушенко Е.С. 1940. Предварительные сведения о фауне позвоночных Стрелецкой и Казацкой степей. $B$ кн.: Труды Центрально-Черноземного государственного заповедника. Вып. 1. M.: 313-320.

91. Россолимо О.Л. (ред.). 1995. Млекопитающие Евразии. I. Rodentia: систематикогеографический справочник. М., Изд-во МГУ, 240 с.

92. Русин М.Ю. 2011. Феномен исчезновения сусликов на Украине в XX веке. В кн.: Тези доповідей конференції молодих дослідників-зоологів. Київ: 12-13.

93. Русин М.Ю. 2013. Редкие и исчезающие виды грызунов степной зоны Восточной Украины. Автореф. дис. ... канд. биол. наук. Киев, 22 с.

94. Русские экспедиции. Зональная научная библиотека УрФУ. URL: https: lib.ideafix.corusour_resourcesexhibitionsnewexhibitiobex_travelrussian_ex (дата обращения: 7 ноября 2020).

95. Сапельников С.Ф. 2008. Млекопитающие. В кн.: Позвоночные животные Воронежского заповедника: аннотированный список. Вып. 2. Воронеж, ВГПУ: 62-73.

96. Сапельников С.Ф. 2019. Почему не получилось создать новую колонию крапчатого суслика (Spermophilus suslicus). B кн.: Млекопитающие России: фаунистика и вопросы териогеографии. Материалы конференции (Ростов-на-Дону, 17-19 апреля 2019 г.). М., Тов-во научных изданий КМК: 247-250.

97. Сапельников С.Ф., Венгеров П.Д. 2007. Орёл-могильник в Воронежском заповеднике. В кн.: Труды Воронежского государственного заповедника. Вып. 25. Воронеж, ВГПУ: 75-95.

98. Сапельников С.Ф., Сапельникова И.И. 2020. Результаты реакклиматизации крапчатого суслика на пастбище и возможные перспективы сохранения вида. $B$ кн.: Пространственновременные аспекты функционирования биосистем. Сборник материалов XVI Международной 
научной экологической конференции, посвящённой памяти Александра Владимировича Присного (Белгород, 24-26 ноября 2020 г.). Белгород, ИД «БелГУ» НИУ «БелГУ»: 112-117.

99. Сапельников С.Ф., Сапельникова И.И. 2020а. Крапчатый суслик (Spermophilus suslicus Guld. 1770) как исчезающий вид и его первое таксономическое описание на территории Воронежской области. $B$ кн.: Труды Воронежского заповедника. Вып. 29. Воронеж, Новый формат: 298-315.

100. Сапельников С.Ф., Соколов А.С., Лада Г.А., Скрылёва Л.Ф. 2007. Придорожная колония крапчатого суслика на автотрассе Астрахань-Москва в Тамбовской области. $B$ кн.: Териофауна России и сопредельных территорий (VIII съезд Териологического общества). Материалы международного совещания. Москва, Т-во научных изданий КМК: 435.

101. Сапельников С.Ф., Соколов А.С., Лада Г.А., Скрылёва Л.Ф. 2007а. Экологоэтологические адаптации крапчатого суслика Spermophilus suslicus к современным условиям среды обитания. $B$ кн.: Труды Воронежского государственного заповедника. Вып. 25. Воронеж: $279-285$.

102. Сапельников С.Ф., Сапельникова И.И. 2019. Постнатальное развитие крапчатого суслика при вольерном содержании. $B$ кн.: Проблемы зоокультуры и экологии. Вып. 3. М., ГАУ «Московский зоопарк», ЕАРАЗА, СОЗАР, Изд-во «ЗооВетКнига»: 134-151.

103. Сапельников С.Ф., Сапельникова И.И. 2020а. Опыт реинтродукции крапчатого суслика (Spermophilus suslicus Güld.) в природном парке «Олений». B кн.: Проблемы зоокультуры и экологии. Вып. 4. М., ГАУ «Московский зоопарк», ЕАРАЗА: 207-216.

104. Свириденко П.А. 1927. Распространение сусликов в Северо-Кавказском крае и некоторые соображения о происхождении фауны предкавказских и калмыцких степей. Известия Северо-Кавказской краевой станции защчиты растений, 3: 123-171.

105. Свириденко П.А. 1940. Грызуны. $B$ кн.: Природа Ростовской области. Ростов-на-Дону, Ростовское областное книгоиздательство: 299-311.

106. Северцов Н.А. 1950. Периодические явления в жизни зверей, птиц и гад Воронежской губернии. 2-е изд. (напечатано по изданию 1855 г). М., Изд-во АН СССР, 308 с.

107. Сент-Илер К.К. 1934. Опыт изучения фауны Воронежского государственного бобрового заповедника. $B$ кн.: Труды Воронежского государственного университета. Т. 8. Вып. 3. Воронеж: 38-55.

108. Силантьев А.А. 1898. Зоологические исследования на участках экспедиции Лесного Департамента в 1894-1896 гг. В кн.: Труды экспедиции Лесного Департамента. Научный отдел. T. IV. Вып. 2. С.-Петербург, Типография Е. Евдокимова, 180 с.

109. Симонович Е.И., Сидельников В.В. 2014. К вопросу о состоянии популяции малого и крапчатого суслика на территории Ростовской области. Международный журнал экспериментального образования, 5-2: 53-54.

110. Ситникова Е.Ф. 2016. Крапчатый суслик - Spermophilus suslicus Guldenstaedt, 1770. $B$ кн.: Красная книга Брянской области. 2-е издание. Брянск, РИО БГУ: 373.

111. Ситникова Е.Ф., Мишта А.В. 2006. Фауна млекопитающих Брянской области: видовой состав, распространение и численность. $B$ кн.: Изучение и охрана биологического разнообразия Брянской области. Материалы по ведению Красной книги Брянской области. Вып. 2. Трубчевск: $107-153$.

112. Скляр О.Ю., Книш М.П., Дугіна О.М. 2018. Зустрічі видів тварин, занесених до Червоної книги України, у регіоні розташування Гетьманського національного природного парку (Сумська область). В кн.: Серія: «Conservation Biology in Ukraine». Вип. 7, Т. 2. Матеріали до 4-го видання Червоної книги України. Тваринний світ. Київ: 258-269.

113. Смирнов П. 2020. Марта, последний странствующий голубь. 1.09.2020. URL: https: elementy.rukartinka_dnya1216Marta_posledniy_stranstvuyushchiy_golub (дата обращения: 13 ноября 2020).

114. Смирнов П.К. 1964. К изучению суточной активности крапчатого суслика. Вестник Ленинградского университета. Серия биологии, 15 (3): 146-148.

115. Смыкова А.В., Родимцев А.С. 2014. Состояние поселений крапчатого суслика (Spermophilus suslicus Güld., 1770) в Тамбовской области. Вестник Тамбовского университета. Серия Естественные и технические науки, 19 (1): 217-219.

116. Соколов А.С., Лада Г.А. 2000. Крапчатый суслик Citellus suslicus (Güldenstädt, 1770). $B$ кн.: Красная книга Тамбовской области. Животные. Тамбов, ИЦ «Тамбовполиграфиздат»: 324 с.

117. Соколов А.С., Лада Г.А. 2012. Крапчатый суслик Spermophilus suslicus (Güldenstädt, 1770). $B$ кн.: Красная книга Тамбовской области. Животные. Тамбов, ООО Издательство «Юлис»: 325. 
118. Соколов В.Е. 1977. Систематика млекопитающих (Отряды: зайцеобразных, грызунов). М., «Высшая школа», 494 с.

119. Стахеев В.В. 2014. Крапчатый суслик - Spermophilus suslicus Guldenstaedt, 1770. В кн.: Красная книга Ростовской области. Издание 2-е. Т. 1. Животные. Ростов-на-Дону: 1270-1275.

120. Титов С.В. 2001. Современное распространение и изменение численности крапчатого суслика Spermophilus suslicus в восточной части ареала. Зоологический журнал, 80 (2): 234-235.

121. Титов С.В. 2005. Суслик крапчатый Spermophilus suslicus (Güldenstädt, 1770). В кн.: Красная книга Пензенской области. Т. 2. Пенза, ОАО ИПК «Пензенская правда»: 175 с.

122. Титов С.В., Кузьмин А.А., Наумов Р.В., Ермаков О.А., Закс С.С., Чернышова О.В. 2015. Динамика ареалов и современное состояние поселений наземных беличьих в правобережных районах Поволжья. Пенза, Изд-во ПГУ, 124 с.

123. Токарский В.А. 2013. Суслики: Spermophilus suslicus (Guldenst., 1769) и Spermophilus pygmaeus (Pallas, 1778) на стыке их ареалов (Сообщение 1. Прошлое распространение). Вісник Харківського наџіонального університету імені В.Н.Каразіна. Серія: біологія, 18 (1079): 138-143.

124. Токарський B.A. 2013а. Крапчастий ховрах Spermophilus suslicus (Güldenstädt, 1770). В кн.: Червона книга Харківської області. Тваринний світ. Харків, ХНУ імені В. Н. Каразіна: 365.

125. Томановский Н., Попов Т. 1914. Гюльденштедт о Воронежской губернии (перевод с немецкого). B кн.: Памятная книжка о Воронежской губернии на 1914 г. Отдел IV-й - научнолитературный. Издание Воронежского Губернского Статистического Комитета. Воронеж, ТипоЛитография Губернского Правления: 113-120.

126. Херувимов В.Д. 1981. Изменения в фауне. В кн.: Атлас Тамбовской области. М.: 15 с.

127. Черняев Н. 1857. Описаніе сусликовъ, обитающихъ въ южной Россіи, и способовъ ихъ истребленія. Санктпетербургъ, Типографія Эдуарда Веймара, 68 с.

128. Чичина В.А., Пиванова С.В., Шубина Ю.Э. 2009. Распределение нор крапчатого суслика в некоторых ландшафтах Липецкого района. $B$ кн.: Вопросы естествознания. Межвузовский сборник научных работ. Вып. 16. Липецк, ЛГПУ: 30-33.

129. Шакун В.В., Максименков М.В. 2013. К охране крапчатого суслика (Citellus suslikus) на территории Кореличкого района Гродненской области. $B$ кн.: Зоологические чтения. Материалы Международной научно-практичемкой конференции, посвященной памяти профессора И.К. Лопатина (Гродно, 14-16 марта 2013 г.). Гродно, ГрГУ им. Я. Купалы: 325-328.

130. Шаповалов А.С. 2019. Суслик крапчатый Spermophilus suslicus Guldenstadt, 1770. $B$ кн.: Красная книга Белгородской области. Редкие и исчезающие растения, лишайники, грибы и животные. 2-е официальное издание. Белгород, ИД «БелГУ» НИУ «БелГУ»: 614.

131. Шаповалов А.С., Присный А.В. 2005. Суслик крапчатый Spermophilus suslicus Guldenstadt, 1770. В кн.: Красная книга Белгородской области. Редкие и исчезающие растения, лишайники, грибы и животные. Официальное издание. Белгород, ОАО «Белгородская областная типография»: $512 \mathrm{c}$.

132. Шекарова О.Н., Савинецкая Л.Е. 2019. Крапчатый суслик в Московской области (ретроспективный анализ). $B$ кн.: Млекопитающие России: фаунистика и вопросы териогеографии. Материалы конференции (Ростов-на-Дону, 17-19 апреля 2019 г.) М., Тов-во научных изданий KMК: 321-324.

133. Шилова С.А., Калинин А.А., Щипанов Н.А., Савинецкая Л.Е., Олейниченко В.Ю. 1994. Антропогенная трансформация фауны мелких млекопитающих севера Ростовской области. Зоологический журнал, 73 (3): 160-166.

134. Шилова С.А., Неронов В.В., Шекарова О.Н., Савинецкая Л.Е. 2010. Динамика поселений крапчатого суслика (Spermophilus suslicus Güld., 1770) на северной границе ареала. Известия РАН. Серия биологическая, 5: 619-624.

135. Шокало С.И. 2019. О состоянии крапчатого суслика (Spermophilus suslicus) в Центральной Беларуси. $B$ кн.: Проблемы зоокультуры и экологии. Вып. 3. М., ГАУ «Московский зоопарк», ЕАРАЗА, СОЗАР, Изд-во «ЗооВетКнига»: 208-215.

136. Шокало С.И., Янкевич Ю.А. 2020. О состоянии крапчатого суслика (Spermophilus suslicus) в Беларуси. B кн.: Экологическая культура и охрана окружающей среды. III Дорофеевские чтения. Материалы Международной научно-практической конференции (Витебск, 28-29 октября 2020 г.). Витебск, ВГУ имени П.М. Машерова: 187-190.

137. Яценко В.Н., Сапельников С.Ф. 2007. Крапчатый суслик Spermophilus suslicus (Guldenstaedt, 1770). В кн.: Позвоночные Тамбовской области. Тамбов: 224-225.

138. Яцентковский Е.В. 1927. Борьба с сусликами в 1924 году. В кн.: Суслики в Белоруссии. Том II. 8. Минск: 1-13. 
139. Glowacinski Z. (ed.). 2002. Red List of Threatened Animals in Poland. Cracow, 155 p. (in Polish)

140. Gueldenstaedt I.A. 1770. Mus Suslica. Novi Commentarii Academiae Scientiarum Imperialis Petropolitanae, 14 (2): 389-402.

141. Gueldenstaedt I.A. 1770a. Spalax, novum glirium Genus. Novi Commentarii Academiae Scientiarum Imperialis Petropolitanae, 14 (2): 409-440.

142. Pallas P.S. 1770. Descriptiones quadrupedum et avium anno 1769. Observatarum. I. Mus citillus. Novi Commentarii Academiae Scientiarum Imperialis Petropolitanae, 14 (2): 548-567.

143. Sapelnikov S.F., Sapelnikova I.I. 2019. Postnatal Development of Speckled Ground Squirrel (Spermophilus suslicus Güld, 1770) (Sciuridae, Mammalia) in Captivity. Povolzhskiy Journal of Ecology, 1: 47-60.

144. Zagorodnyuk I., Glowacinski Z., Gondek A. 2008. Spermophilus suslicus. The IUCN Red List of Threatened Species 2008: e.T20492A9208074. http:dx.doi.org10.2305IUCN. UK.2008.RLTS.T20492A9208074.en.

145. Ziółek M., Kozieł M., Czubla P. 2017. Zmiany liczebności populacji susła perełkowanego Spermophilus suslicus w polsce wschodniej. Polish Journal of Natural Sciences, 32 (1): 91-104. (in Polish)

\section{References}

1. Aleksandrov D.Yu., Ivanova A.D., Titov S.V., Ermakov O.A. 2019. Nakhodka zheltogo suslika (Spermophilus fulvus) v Chernykh zemlyakh Kalmykii i drugie sluchai introduktsii suslikov [Finding the yellow ground squirrel (Spermophilus fulvus) in the Black Lands of Kalmykia and other cases of the introduction of ground squirrels]. In: Mammals of Russia: faunistics and zoogeographical issues. Proceedings of the conference (Rostov-on-Don, April 17-19, 2019). Moscow, KMK Scientific Press: $8-10$.

2. Aleksandrov V.N., Nedosekin V.Yu. 1998. Nazemnye pozvonochnye zhivotnye Lesostepnoy opytno-selektsionnoy stantsii i ee okrestnostey [Terrestrial vertebrates of the Forest-Steppe Experimental Breeding Station and its environs]. In: Voprosy estestvoznaniya [Questions of natural science]. Iss. 6. Lipetsk: 57.

3. Asoskova N.I., Kheruvimov V.D. 1966. Izmeneniya v okhotnich'e-promyslovoy faune [Changes in the hunting and commercial fauna]. In: Atlas Tambovskoy oblasti [Atlas of the Tambov region]. Moscow, $11 \mathrm{p}$.

4. Barabash-Nikiforov I.I. 1957. Krapchatyy suslik - Citellus suslica Güld [Speckled ground squirrel - Citellus suslica Güld]. In: Zveri yugo-vostochnoy chasti Chernozemnogo tsentra [Animals of the southeastern part of the Black Earth Center]. Voronezh: 219-232.

5. Barabash-Nikiforov I.I., Pavlovskiy N.K. 1948. Fauna nazemnykh pozvonochnykh Voronezhskogo gosudarstvennogo zapovednika [Fauna of terrestrial vertebrates of the Voronezh State Reserve]. In: Trudy Voronezhskogo gosudarstvennogo zapovednika [Proceedings of the Voronezh State Reserve]. Iss. 2. Voronezh: 7-128.

6. Batochenko V.M. 2018. Reєstratsiï deyakikh vidiv fauni zanesenikh do Chervonoï knigi Ukraïni na Volino-Podilli [Registration of some species of fauna listed in the Red Book of Ukraine in Volyn-Podillya]. In: Seriya: «Conservation Biology in Ukraine». Vip. 7, T. 1. Materiali do 4-go vidannya Chervonoï knigi Ukraïni. Tvarinniy svit [Series: "Conservation Biology in Ukraine". Vip. 7, Vol. 1. Materials for the 4th edition of the Red Book of Ukraine. Fauna]. Kyiv: 22-23. (in Ukrainian)

7. Belik V.P. 2011. Krapchatyy suslik v Rostovskoy oblasti: fantom ili real'nost'? [Speckled gopher in the Rostov region: phantom or reality?]. In: Problemy Krasnykh knig i prepodavanie okhrany prirody [Problems of the Red Data Books and Teaching Nature Conservation]. Rostov-on-Don: 105-108.

8. Belyachenko A.V. 2006. Suslik krapchatyy - Spermophilus suslicus (Guldenstaedt, 1770) [Spotted ground squirrel - Spermophilus suslicus (Guldenstaedt, 1770)]. In: Red Data Book of the Saratov Region. Mushrooms. Lichens. Plants. Animals. Saratov, Publishing House of the Chamber of Commerce and Industry of the Saratov Region: 483-485.

9. Brandler O.V., Vlasova O.P., Vlasov E.A. 2012. Reintroduktsiya stepnogo surka v Tsentral'noChernozemom zapovednike [Reintroduction of steppe marmot in the Central Black Earth Reserve]. Stepnoy byulleten', 35: 50-55.

10. Budnichenko A.S., Rymashevskiy V.K., Skoptsov A.G., Strokov V.V. 1964. Keys to vertebrates of the Tambov region. Voronezh, Tsentral'no-Chernozemnoe knizhnoe izd-vo, $120 \mathrm{p}$.

11. Bystrakova N.V., Ermakov O.A., Titov S.V. 2005. Khromosomnyy marshrut na Srednem Donu [Chromosome route in the Middle Don]. Vestnik VOGIS, 9 (1): 67-69. 
12. Vinogradov B.S. 2005. Biologicheskiya nablyudeniya nad krapchatym suslikom (Spermophilus guttatus Temm.) (Pechataetsya s sokrashcheniyami po ottisku $1914 \mathrm{~g}$ ) [Biological observations of the speckled ground squirrel (Spermophilus guttatus Temm.) (Reprinted with abbreviations from the 1914 print)]. Izvestiya Muzeynogo fonda im. A.A. Braunera, II (2): 15-16.

13. Vinogradov B.S., Argipulo A.I. 1941. Fauna of the USSR. Mammals. Keys to Rodents. Moscow-Leningrad, Izd-vo AN SSSR: 243.

14. Vinogradov B.S., Obolenskiy S.I. 1932. Vrednye i poleznye v sel'skom khozyaystve mlekopitayushchie [Mammals harmful and useful in agriculture]. Moscow-Leningrad, Gosud. izd-vo sel'skokhoz. i kolkhozno-kooperat. literatury, $222 \mathrm{p}$.

15. Vlasov A., Brandler O. 2011. Krapchatyy suslik ischez v Kurskoy oblasti? [Has the speckled ground squirrel disappeared in the Kursk region?]. Stepnoy byulleten', 33: 35.

16. Vlasov A.A. 125th anniversary of the birth of E.S. Ptushenko. Available at: http:zapovedkursk.rupress-centrnovosti125-let-so-dnya-rozhdeniya-e-s-ptushenko.html (accessed January 28, 2021).

17. Vlasov A.A. 1995. Sovremennoe sostoyanie populyatsiy stepnykh vidov mlekopitayushchikh Tsentral'no-Chernozemnogo zapovednika i perspektivy ikh dal'neyshego sushchestvovaniya [The current state of populations of steppe species of mammals of the Central Chernozem Reserve and the prospects for their further existence]. In: Problemy sokhraneniya raznoobraziya prirody stepnykh i lesostepnykh regionov [Problems of conservation of the diversity of the nature of the steppe and forest-steppe regions]. Materials of the Russian-Ukrainian scientific conference dedicated to the 60th anniversary of the Central Black Earth Reserve. Moscow, KMK Scientific Press: 226-227.

18. Vlasov A.A. 2001. Izmenenie teriofauny lesostepnykh zapovednikov [Changes in theriofauna of forest-steppe reserves]. In: Trudy Assotsiatsii osobo okhranyaemykh prirod. territoriy Tsentral'nogo Chernozem'ya Rossii. Vyp. 2. Zoologicheskie issledovaniya v zapovednikakh Tsentral'nogo Chernozem'ya [Proceedings of the Association of Specially Protected Nature territories of the Central Black Earth Region of Russia. Iss. 2. Zoological research in the reserves of the Central Black Earth Region]. Tula: 5-13.

19. Vlasov A.A., Vlasova O.P. 2006. Pozvonochnye zhivotnye, rekomenduemye k zaneseniyu v Krasnuyu knigu Kurskoy oblasti [Vertebrates recommended for inclusion in the Red Data Book of the Kursk region]. In: Issledovaniya po Krasnoy knige Kurskoy oblasti [Research on the Red Data Book of the Kursk Region]. Kursk, 21-24.

20. Gmelin S.G. 1806 (1771). Puteshestvie po Rossii dlya issledovaniya trekh tsarstv estestva. Ch. 1. Puteshestvie iz Sanktpeterburga do Cherkaska, glavnogo goroda Donskikh kazakov v 1768 i 1769 godakh [Travel across Russia to explore the three kingdoms of nature. Part 1. Travel from St. Petersburg to Cherkask, the main city of the Don Cossacks in 1768 and 1769]. Translation from German, $2^{\text {nd }}$ ed. Saint-Petersburg, Imp. Acad. Science, 272 p.

21. Gorbachev S.N. 1925. Pozvonochnye zhivotnye [Vertebrates]. In: Priroda Orlovskogo kraya [The nature of the Oryol region]. Oryol: 411-463.

22. Grave G.L. 1933. Promyslovye zveri [Hunting animals]. In: Okhotnich'i promysly v Zapadnoy oblasti [Hunting in the Western region]. Smolensk, Zapgiz: 44-79.

23. Danilov P.N. 1868. Opisanie vidov rukokrylykh i nasekomykh, vodyashchikhsya v yugovostochnoy chasti Orlovskoy gubernii, s estestvenno-istoricheskim vzglyadom na mestnosti, zanimaemoyu Eletskim uezdom [Description of the species of bats and insects found in the southeastern part of the Oryol province, with a natural-historical view of the area occupied by the Yelets district]. [Soch.] P.N. Danilova. Photocopy. Moscow, Tipografiya Selivanovskogo, 32 p.

24. Demyanchik V.T. 2006. Krapchatyy suslik Citellus suslicus (Güldenstaedt, 1770), Spermophilus suslicus (Güldenstaedt, 1770) [Spotted ground squirrel Citellus suslicus (Güldenstaedt, 1770), Spermophilus suslicus (Güldenstaedt, 1770)]. In: Red Book of the Republic of Belarus. Available at: http: redbook.minpriroda.gov.byanimalsinfo.html? Id = 11 (accessed March 11, 2019).

25. Demianchyk V.V., Nikiforov M.E. 2017. Synanthropic ecological complex and structure of the population of vertebrate animals of residential territories of Belarusian Polesie. Proceedings of the National Academy of Sciences of Belarus. Biological series, 3: 7-17. (in Russian)

26. Denisova I.S. 1996. Fauna melkikh mlekopitayushchikh Kazatskogo uchastka Tsentral'noChernozemnogo zapovednika [Fauna of small mammals of the Cossack area of the Central Chernozem reserve]. In: Fauna Tsentral'nogo Chernozem'ya i formirirovaniye ekologicheskoy kul'tury [Fauna of the Central Black Earth Region and the Formation of Ecological Culture]. Conference materials. P. 2. Lipetsk: $39-40$.

27. Denisova I.S. 1997. Naselenie melkikh mlekopitayushchikh Kazatskogo uchastka Tsentral'noChernozemnogo zapovednika i nekotorye osobennosti ego formirovaniya [Population of small mammals 
of the Cossack area of the Central Chernozem reserve and some features of its formation]. In: Mnogoletnyaya dinamika prirodnykh protsessov i biologicheskoe raznoobrazie zapovednykh ekosistem Tsentral'nogo Chernozem'ya i Altaya. Trudy Tsentral'no-Chernozemnogo gosudarstvennogo zapovednika. Vyp. 15 [Long-term dynamics of natural processes and biological diversity of protected ecosystems of the Central Black Earth Region and Altai. Proceedings of the Central Black Earth State Reserve. Iss. 15]. Moscow: 171-180.

28. Dobrovolskiy O.P. 2013. Izmeneniya v sostave okhotnich'ikh mlekopitayushchikh Rostovskoy oblasti v poslednie desyatiletiya [Changes in the composition of hunting mammals in the Rostov region in recent decades]. Abstract. diss. ... cand. biol. sciences. Rostov-on-Don, 24 p.

29. EARAZA: information collections 2005-2020. № 24-39. Available at: http:earaza.ru?page_id=31 (accessed December 8, 2020).

30. Eliseeva V.I. 1959. Spisok mlekopitayushchikh i ptits Tsentral'no-Chernozemnogo zapovednika i nekotorye dannye po fenologii ikh migratsiy i razmnozheniya [List of mammals and birds of the Central Black Earth Reserve and some data on the phenology of their migration and reproduction]. In: Trudy Tsentral'no-Chernozemnogo gosudarstvennogo zapovednika. Vyp. 5 [Proceedings of the Central Black Earth State Reserve. Iss. 5]. Kursk, Kursk publishing house: 377-418.

31. Eliseeva V.I. 1977. Fauna nazemnykh pozvonochnykh uchastka Barkalovka Tsentral'noChernozemnogo zapovednika [Fauna of terrestrial vertebrates in the Barkalovka area of the Central Chernozem Reserve]. In: Materialy k izucheniyu prirodnykh ekosistem Tsentral'noy lesostepi Russkoy ravniny. Trudy Tsentral'no-Chernozemnogo gos. zapovednika. Vyp. 8 [Materials for the study of natural ecosystems of the Central forest-steppe of the Russian Plain. Proceedings of the Central Black Earth State Reserve. Iss. 8]. Voronezh, Tsentral'no-Chernozemnoe knizhnoe izd-vo: 55-71.

32. Zagorodnyuk I. 2006. Ssavtsi skhidnikh oblastey Ukraïni: sklad ta istorichni zmini fauni [Mammals of the eastern regions of Ukraine: composition and historical changes of fauna]. In: Pratsi Teriologichnoï shkoli, Teriofauna skhodu Ukraïni. Vyp. 7 [Proceedings of the Theriological School, Theriofauna of eastern Ukraine. Iss. 7]. Luhansk: 217-259. (in Ukrainian)

33. Zagorodnyuk I.V., Fedorchenko A.A. 1995. Allopatricheskie vidy sredi gryzunov gruppy Spermophilus suslicus (Mammalia) [Allopatric species among rodents of the group Spermophilus suslicus (Mammalia)]. Vestnik zoologii, 5-6: 49-58.

34. Zdeshneva I.E. 1992. Osobennosti landshaftnogo rasprostraneniya krapchatogo suslika na vostoke Srednerusskoy vozvyshennosti [Features of the landscape distribution of the speckled ground squirrel in the east of the Central Russian Upland]. In: Chteniya pamyati professora V.V. Stanchinskogo [Readings in memory of Professor V.V. Stanchinsky]. Smolensk: 89-93.

35. Zozulin G.M. 1950. Streletskaya step' [Streletskaya steppe] Kursk, Izd-vo «Kurskaya pravda», $71 \mathrm{p}$.

36. Il'yashenko V.Yu., Shatalkin A.I., Kuvaev A.V., Komendantov A.Yu., Britaev T.A., Kos'yan A.R., Pavlov D.S., Shilin N.I., Anan'eva N.B., Tuniev B.S., Semenov D.V., Syroechkovskiy E.E., Morozov V.V., Mishchenko A.L., Rozhnov V.V., Poyarkov A.D. 2018. Redkie i nakhodyashchiesya pod ugrozoy ischeznoveniya zhivotnye Rossii: Materialy k Krasnoy knige Rossiyskoy Federatsii [Rare and Endangered Animals of Russia. Materials for the Red Data Book of the Russian Federation]. Moscow, KMK Scientific Press, 69 p.

37. Kalmatskiy M. 2016. Kto svistit na NPS? [Who whistles at the PS?]. Truboprovodnyy transport nefti, 9: 68-71. Available at: https://www.transneft.ru/u/eco_publish_file/132/sysliki.pdf (accessed February 9, 2021).

38. Klimov A.S. 2018. Suslik krapchatyy Spermophilus suslicus (Güldenstaedt, 1770) [Spotted ground squirrel Spermophilus suslicus (Güldenstaedt, 1770)]. In: Red Data Book of the Voronezh Region. Vol. 2. Animals. Voronezh, Tsentr dukhovnogo vozrozhdeniya Chernozemnogo kraya, $417 \mathrm{p}$.

39. Klimov S.M. 2010. Materialy po faune nazemnykh pozvonochnykh zapovednika «Galich'ya gora» i ego okrestnostey [Materials on the fauna of terrestrial vertebrates of the reserve "Galichya Gora" and its environs]. In: Ekologicheskie issledovaniya v zapovednike «Galich'ya gora» [Environmental research in the reserve "Galichya Gora"]. Iss. 2. Voronezh, Izdatel'sko-poligraficheskiy tsentr Voronezhskogo gosudarstvennogo universiteta: 69-82.

40. Klimov S.M., Aleksandrov V.N. 1993. Zhivotnyy mir Lipetska i ego okhrana [Animal world of Lipetsk and its protection]. In: Priroda Lipetskoy oblasti i ee okhrana [The nature of the Lipetsk region and its protection]. Iss. 7. Voronezh: 69-79.

41. Klimov S.M., Sarychev V.S., Kuznetsova V.T. 1994. Sostoyanie zhivotnogo mira i zadachi dal'neyshikh issledovaniy [Condition of the animal world and tasks for further research]. In: Sovremennoe sostoyanie rastitel'nogo i zhivotnogo mira Lipetskoy oblasti i problemy ikh okhrany. Ch. 2 
[The current state of the flora and fauna of the Lipetsk region and the problems of their protection. Part 2]. Lipetsk: 5.

42. Komyagina O. 2013. V Korelichskom rayone raspakhali mesto obitaniya redkogo vida suslika [Habitat of a rare species of ground squirrel was plowed up in Korelichi district]. Komsomolskaya Pravda - Belarus. 10.07.2013. Available at: https: www.kp.bydaily261053000893 (accessed May 20, 2021).

43. Konstantinov V.M., Klimov S.M., Khokhlov A.N. 1996. Sinantropizatsiya i urbanizatsiya pozvonochnykh zhivotnykh Evropeyskogo Tsentra Rossii [Synanthropization and urbanization of vertebrates of the European Center of Russia]. In: Fauna Tsentral'nogo Chernozem'ya i formirovanie ekologicheskoy kul'tury [Fauna of the Central Black Earth Region and the Formation of Ecological Culture]. Materials of the First Regional Conference (Lipetsk, October 23-26, 1996). Part 1. Lipetsk: 4-8.

44. Korol'kova G.E. 1975. Nazemnye pozvonochnye zhivotnye Tellermanovskogo lesa i ikh funktsional'naya rol' v biogeotsenozakh lesostepnykh dubrav [Terrestrial vertebrates of the Tellerman forest and their functional role in biogeocenoses of forest-steppe oak forests]. In: Dubravy lesostepi $\mathrm{v}$ biotsenologicheskom osveshchenii [Oak forest-steppe in biocenological lighting]. Moscow, Nauka: 229-254.

45. Kosyrevskoe cemetery (old). Encyclopedia. Lipetsk and the region. 10/16/2019. Available at: https: //xn----8sbnlbgcddd9bs6e.xn--p1ai/wiki/k/5298/ (accessed May 31, 2021).

46. Red Data Book of the Kursk Region. 2002. Vol. 1. Rare and endangered animal species. Tula, 120. (in Russian)

47. Kren' A.G. 1939. Pozvonochnye zhivotnye zapovednika "Les na Vorskle" [Vertebrates of the Nature Reserve "Les na Vorskle"]. Uchenyye zapiski LGU. Seriya biologicheskikh nauk, 28 (7): 184-206.

48. Ksenzhopol'skiy A.V. 1915. Zametka o volynskikh suslikakh i nekotorykh drugikh zhivotnykh iz porody gryzunov. Myshinaya napast' na Volyni v 1913-1914 godakh [A note about Volyn ground squirrels and some other animals from the breed of rodents. Mouse attack on Volhynia in 19131914]. Zhitomir: 25-42.

49. Lavrov L.S., D'yakov Yu.V., Nikitin N.M. 1992. Mlekopitayushchie [Mammals]. In: Flora i fauna zapovednikov SSSR. Pozvonochnye zhivotnye Voronezhskogo zapovednika (Annotirovannyy spisok vidov) [Flora and fauna of the reserves of the USSR. Vertebrates of the Voronezh Reserve (Annotated list of species)]. Moscow: 32-40.

50. Litvinova S.S., Pivanova S.V., Shubina Yu.E. 2009. Troficheskie svyazi krapchatogo suslika $\mathrm{v}$ prirodno-antropogennom landshafte [Trophic relationships of the speckled ground squirrel in the natural-anthropogenic landscape]. In: Rol' estestvennykh nauk $\mathrm{v}$ reshenii problem sovremennogo obshchestva [The role of natural sciences in solving problems of modern society]. Materials of the AllRussian Student Conference. Lipetsk: 70-72.

51. Marchenko N.F. 1996. Dinamika vidovogo raznoobraziya teriofauny Khoperskogo zapovednika i okruzhayushchikh landshaftov [Dynamics of the species diversity of the theriofauna of the Khopyor reserve and surrounding landscapes]. In: Fauna Tsentral'nogo Chernozem'ya i formirovanie ekologicheskoy kul'tury [Fauna of the Central Black Earth Region and the Formation of Ecological Culture]. Conference materials. P. 2. Lipetsk: 49-51.

52. Marchenko N.F. 2003. Ischeznovenie krapchatogo suslika Sitellus suslicus v okrestnostyakh Khoperskogo zapovednika [Disappearance of the speckled ground squirrel Citellus suslicus in the vicinity of the Khopersky Nature Reserve]. In: Teriofauna Rossii i sopredel'nykh territoriy - VII s"ezd Teriologicheskogo obshchestva [Theriofauna of Russia and adjacent territories VII Congress of the Theriological Society]. Materials of the International Meeting (Moscow, February 6-7, 2003). Moscow: 215.

53. Marchenko N.F. 2016. Mlekopitayushchie Khoperskogo zapovednika. Povidovoy obzor. Otryad Rodentia, Bowdich, 1821 - Gryzuny [Mammals of the Khopyorsky Reserve. Species overview. Order Rodentia, Bowdich, 1821 - Rodents]. In: Trudy Khoperskogo gosudarstvennogo zapovednika. Vyp. 10 [Proceedings of the Khopyorsky State Reserve. Iss. 10]. Voronezh, Izdatel'sko-poligraficheskiy tsentr "Nauchnaya kniga": 82-153.

54. Marchenko N.F., Pechenyuk A.D. 2000. Materialy k kadastru teriofauny TsChR (Novokhoperskiy rayon Voronezhskoy oblasti) za period s 1951 po $2000 \mathrm{gg}$. [Materials for the cadastre of theriofauna of the Central Black Earth Region (Novokhopyorsk District of the Voronezh Region) for the period from 1951 to 2000]. In: Ekologo-faunisticheskie issledovaniya v Tsentral'nom Chernozem'e i sopredel'nykh territoriyakh [Ecological and faunistic research in the Central Black Earth Region and adjacent territories]. Lipetsk, LGPU: 168-171.

55. Mezhzherin S.V. 2009. Suslik krapchatyy Spermophilus suslicus (Güldenstaedt, 1770) [Spotted ground squirrel Spermophilus suslicus (Güldenstaedt, 1770)]. In: Red Book of Ukraine. 
Animals. Available at: http: redbook-ua.orgruitemspermophilus-suslicus-gueldenstaedt (accessed February 7, 2018).

56. Minoranskij V.A., Sidelnikov V.V., Simonovich E.I. 2015. Status of the populations of gophers (Spermophilus spp.) on the Don. Fundamental research, 2-2: 277-280. (in Russian)

57. Mishta A.V. Krapchatyy suslik Spermophilus suslicus Guldenstaedt, 1770 [Spotted ground squirrel Spermophilus suslicus Guldenstaedt, 1770]. In: Red Book of the Bryansk Region. Animals. Bryansk, ZAO "Izd-vo "Chitay-gorod": 44-45.

58. Nedosekin V.Yu. 2007. Sovremennoe sostoyanie krapchatogo suslika na severe Srednerusskoy vozvyshennosti [The current state of the speckled ground squirrel in the north of the Central Russian Upland]. In: Ekologicheskie issledovaniya v zapovednike "Galich'ya gora" [Ecological research in the reserve "Galichya Gora"]. Iss. 1. Voronezh, Voronezh State University: 133-135.

59. Nedosekin V.Yu. 2009. Krapchatyy suslik Spermophilus suslicus Guldenstaedt, 1770 [Spotted ground squirrel Spermophilus suslicus Guldenstaedt, 1770]. In: Pozvonochnye Lipetskoy oblasti. Kadastr [Vertebrates of the Lipetsk region. Cadastre]. Voronezh, Voronezh State University Publishing and Printing Center: 399-400.

60. Nedosekin V.Yu. 2014. Mlekopitayushchie [Mammals]. In: Priroda Plyushchani [Plyushchan's nature]. Voronezh, Izdatel'stvo "Nauchnaya kniga": 243-253.

61. Nedosekin V.Yu. 2016. Klass mlekopitayushchie - Mammalia [Class mammals Mammalia]. In: Pozvonochnye zapovednika «Galich'ya gora» [Vertebrates of the Galichya Gora reserve]. Voronezh, Voronezh State University Publishing House: 144-165.

62. Nedosekin V.Yu., Klimov S.M., Sarychev V.S., Aleksandrov V.N. 1996. Pozvonochnye zhivotnye Lipetskoy oblasti i ikh okhrana [Vertebrates of the Lipetsk region and their protection]. Lipetsk, Izd-vo LGPI i LIUU: 79.

63. Nedosekin V.Yu., Ushakov M.V. 2005. O sostoyanii krapchatogo suslika v Lipetskoy oblasti [About the state of the speckled ground squirrel in the Lipetsk region]. In: Susliki Evrazii (rody Spermophilus, Spermophilopsis): proiskhozhdenie, sistematika, ekologiya, povedenie, sokhranenie vidovogo raznoobraziya [Gophers of Eurasia (genera Spermophilus, Spermophilopsis): origin, taxonomy, ecology, behavior, conservation of species diversity]. Materials of the Russian scientific conference (Moscow, November 16-17, 2005). Moscow, KMK Scientific Press: 65-66.

64. Ognev S.I. 1947. Zveri SSSR i prilezhashchikh stran. T. 5. Gryzuny [Animals of the USSR and adjacent countries. T. 5. Rodents]. Moscow-Leningrad., Izd-vo AN SSSR: 142-162.

65. Ognev S.I., Vorobiev K.A. 1923. Fauna nazemnykh pozvonochnykh Voronezhskoy gubernii [Fauna of terrestrial vertebrates of the Voronezh province]. Moscow, Izd-vo Narkomzema "Novaya derevnya", $254 \mathrm{p}$.

66. Pavlinov I.Ya., Kruskop S.V., Varshavskiy A.A., Borisenko A.V. 2002. Nazemnye zveri Rossii [Land animals of Russia]. M., KMK Scientific Press, 298 p.

67. Pavlinov I.Ya., Lissovsky A.A. (Eds). 2012. The Mammals of Russia: A Taxonomic and Geographic Reference. Moscow, KMK Scientific Press, 604 p.

68. Pavlinov I.Ya., Rossolimo O.L. 1987. Sistematika mlekopitayushchikh SSSR [Systematics of mammals in the USSR]. Moscow, Izd-vo MGU, 285 p.

69. Pavlinov I.Ya., Rossolimo O.L. 1998. Sistematika mlekopitayushchikh SSSR: dopolneniya [Taxonomy of mammals of the USSR: additions]. Moscow, Izd-vo MGU, 190.

70. Pavlova E.A. 1951. Suslik [Gopher]. Moscow, Zagotizdat, 80.

71. Petrovskiy Yu.T. 1960. Biologicheskie osobennosti krapchatogo suslika v Belorussii [Biological features of the speckled ground squirrel in Belarus]. Abstract. dis. ... cand. biol. sciences. Minsk, $18 \mathrm{p}$.

72. Petrovskiy Yu.T. 1961, Osobennosti ekologii krapchatogo suslika v Belorussii [Features of the ecology of the speckled ground squirrel in Belarus]. Zoologicheskiy zhurnal, 40 (5): 736-748.

73. Pechenyuk A.D. 2005. Mlekopitayushchie i ptitsy Novokhoperskogo rayona [Mammals and birds of the Novokhopyorsk region]. In: Sostoyanie osobo okhranyaemykh prirodnykh territoriy Evropeyskoy chasti Rossii [The condition of specially protected natural areas of the European part of Russia]. Collection of scientific articles dedicated to the 70th anniversary of the Khopyorsky reserve. Voronezh, Voronezh University Publishing House: 401-406.

74. Pivanova S.V. Otnoshenie naseleniya k krapchatomu susliku (Citellus suslicus Güld.) [Attitude of the population to the speckled ground squirrel (Citellus suslicus Güld.)]. 2008. In: Aktual'nye problemy estestvennykh nauk i ikh prepodavaniya [Actual problems of natural sciences and their teaching]. Lipetsk, LGPU: 232-234. 
75. Pivanova S.V. 2008a. Sezonnaya aktivnost' krapchatogo suslika (Citellus suslicus Güld., 1770) v prirodno-antropogennom landshafte okrestnostey g. Lipetska [Seasonal activity of the speckled ground squirrel (Citellus suslicus Güld., 1770) in the natural-anthropogenic landscape of the vicinity of Lipetsk]. In: Problemy ekologii i ekologicheskoy bezopasnosti Tsentral'nogo Chernozem'ya Rossiyskoy Federatsii [Problems of ecology and ecological safety of the Central Black Earth Region of the Russian Federation]. Materials of the XII International Scientific and Practical Conference (Lipetsk, December 3, 2008). Lipetsk, LEGI: 46-47.

76. Pivanova S.V. 2009. Rasprostranenie krapchatogo suslika (Citellus suslicus Güld., 1770) v Tsentral'nom Chernozem'e [Distribution of the speckled ground squirrel (Citellus suslicus Güld., 1770) in the Central Black Earth Region]. In: Collection of scientific works of graduate students and applicants. Issue 6. Part II. Lipetsk, LGPU: 63-64.

77. Pivanova S.V. 2009a. Kharakter razmeshcheniya nor krapchatogo suslika v prirodnoantropogennom landshafte Lipetskogo rayona [The nature of the distribution of burrows of the speckled ground squirrel in the natural-anthropogenic landscape of the Lipetsk region]. In: Aktual'nye problemy estestvennykh nauk i ikh prepodavaniya [Actual problems of natural sciences and their teaching]. Lipetsk, LGPU: $131-134$.

78. Pivanova S.V. 2011. Kharakteristika poseleniya krapchatogo suslika v Zadonskom rayone Lipetskoy oblasti [Characteristics of the settlement of the speckled ground squirrel in the Zadonsk district of the Lipetsk region]. In: Aktual'nye problemy ekologii i prirodopol'zovaniya [Actual problems of ecology and nature management]. Collection of scientific papers. Iss. 13. P. 1. Moscow, RUDN: 153-156.

79. Pivanova S.V., Shubina Yu.E. 2009. Faktory, vliyayushchie na chislennost' krapchatogo suslika (Spermophilus suslicus Güldenstaedt, 1770) v prirodno-antropogennykh landshaftakh [Factors affecting the abundance of speckled ground squirrel (Spermophilus suslicus Güldenstaedt, 1770) in natural and anthropogenic landscapes]. In: Upravlenie chislennost'yu gryzunov-vrediteley (pest management) i problemy sokhraneniya biologicheskogo raznoobraziya [Pest management and problems of biodiversity conservation]. Materials of the Russian scientific-practical conference with international participation (Moscow, November 17-18, 2009). Moscow, IPEE RAS: 48-49.

80. Pivanova S.V., Shubina Yu.E. 2009a. K voprosu o neobkhodimosti regulyatsii krapchatogo suslika $\mathrm{v}$ usloviyakh prirodno-antropogennykh landshaftov Lipetskogo rayona [On the issue of the need to regulate the speckled ground squirrel in the natural and anthropogenic landscapes of the Lipetsk region]. In: Ekologicheskaya bezopasnost' regiona [Ecological safety of the region]. Materials of the International Scientific and Practical Conference (Bryansk, October 29-30, 2009). Bryansk, Publishing house "Kursiv": 276-277.

81. Pivanova S.V., Shubina Yu.E. 2010. Gorodskoe kladbishche kak mesto sokhraneniya populyatsii krapchatogo suslika [City cemetery as a preservation site for the speckled ground squirrel population]. In: Vidovye populyatsii i soobshchestva $\mathrm{v}$ antropogenno transformirovannykh landshaftakh: sostoyanie i metody ego diagnostiki [Species populations and communities in anthropogenically transformed landscapes: state and methods of its diagnostics]. Materials of the XI Intern. scientific and practical ecology. conf. Belgorod, POLITERRA: 177-178.

82. Pivanova S.V., Shubina Yu.E. 2010a. Razmnozhenie krapchatogo suslika v prigorodnoy zone goroda Lipetska [Reproduction of a speckled ground squirrel in the suburban area of the city of Lipetsk]. In: Pervye Mezhdunarodnye Bekkerovskie chteniya (27-29 maya 2010 g.) [First International Becker Readings (May 27-29, 2010)]. Ch. 1. Volgograd: 495-496.

83. Pivanova S.V., Shubina Yu.E. 2010b. Sostoyanie populyatsii krapchatogo suslika v prirodnoantropogennom landshafte gorodskogo kladbishcha i ego okrestnostey [Condition of the speckled ground squirrel population in the natural-anthropogenic landscape of the city cemetery and its environs]. In: Problemy izucheniya i vosstanovleniya landshaftov lesostepnoy zony [Problems of study and restoration of landscapes of the forest-steppe zone]. Collection of scientific articles. Tula: 268-270.

84. Plechova Z.N., Dimitriev A.V., Soldatov S.P. 2010. Suslik krapchatyy - Spermophilus suslicus (Gueldenstaedt, 1770) [Spotted ground squirrel - Spermophilus suslicus (Gueldenstaedt, 1770)]. In: Red Data Book of the Chuvash Republic. Vol. 1. Part 2. Rare and endangered species of animals. Cheboksary, GUP "IPK Chuvashiya": 272-273.

85. The population of the "Red Book" animal is on the brink of disaster. Information service "EuroBelarus". 07.08.2013. Available at: https: eurobelarus.infonewssociety20130708pod-miromraspahali-koloniyu-suslikov.html (accessed May 20, 2021). (in Russian)

86. Predtechenskiy S.A. 1928. O faune nazemnykh pozvonochnykh Tambovskogo kraya [About the fauna of terrestrial vertebrates of the Tambov region]. Izvestiya Tambovskogo obshchestva izucheniya prirody i kul'tury mestnogo kraya, 3: 3-31. 
87. Order of the Ministry of Natural Resources and Environment of the Russian Federation dated March 24, 2020 No. 162 "On approval of the List of wildlife objects included in the Red Book of the Russian Federation". URL: http: docs.cntd.rudocument564578614 (date of treatment November 17, 2020). (in Russian)

88. Proyavka S.V., Shubina Yu.E., Savinetskaya L.E., Shekarova O.N. 2017. Morphological characteristics of the speckled ground squirrel Spermophilus suslicus of the central part of European Russia. University proceedings. Volga region. Natural sciences, 2 (18): 3-10. (in Russian)

89. Ptushenko E.S. 1937. Materialy k poznaniyu teriologicheskoy fauny Kurskogo kraya [erials for the knowledge of the theriological fauna of the Kursk region]. In: Collection in memory of academician M.A. Menzbier. Moscow-Leningrad, Izd-vo AN SSSR: 409-501.

90. Ptushenko E.S. 1940. Predvaritel'nye svedeniya o faune pozvonochnykh Streletskoy i Kazatskoy stepey [Preliminary information about the vertebrate fauna of the Streletskaya and Kazatskaya steppes]. In: Proceedings of the Central Black Earth State Reserve. Iss. 1. Moscow: 313-320.

91. Rossolimo O.L. (ed.). 1995. Mlekopitayushchie Evrazii. I. Rodentia: sistematikogeograficheskiy spravochnik [Mammals of Eurasia. I. Rodentia: a systematic and geographical reference]. Moscow, Moscow State University Publishing House, 240 p.

92. Rusin M.Yu. 2011. Fenomen ischeznoveniya suslikov na Ukraine v XX veke [The phenomenon of the disappearance of ground squirrels in Ukraine in the XX century]. In: Abstracts of the conference of young researchers-zoologists. Kyiv: 12-13.

93. Rusin M.Yu. 2013. Redkie i ischezayushchie vidy gryzunov stepnoy zony Vostochnoy Ukrainy [Rare and endangered rodent species in the steppe zone of Eastern Ukraine]. Abstract. dis. ... cand. biol. sciences. Kiev, 22 p.

94. Russian expeditions. Zonal Scientific Library of UrFU. Available at: https: lib.ideafix.corusour_resourcesexhibitionsnewexhibitiobex_travelrussian_ex (accessed November 7, 2020). (in Russian)

95. Sapelnikov S.F. 2008. Mlekopitayushchie [Mammals]. In: Pozvonochnye zhivotnye Voronezhskogo zapovednika: annotirovannyy spisok [Vertebrates of the Voronezh Reserve: an annotated list]. Iss. 2. Voronezh, Voronezh State Pedagogical University: 62-73.

96. Sapelnikov S.F. 2019. Pochemu ne poluchilos' sozdat' novuyu koloniyu krapchatogo suslika (Spermophilus suslicus) [Why it was not possible to create a new colony of speckled ground squirrel (Spermophilus suslicus)]. In: Mlekopitayushchie Rossii: faunistika i voprosy teriogeografii [Mammals of Russia: faunistics and questions of theriogeography]. Conference materials (Rostov-on-Don, April 17-19, 2019), Moscow, KMK Scientific Press: 247-250.

97. Sapelnikov S.F., Vengerov P.D. 2007. Orel-mogil'nik v Voronezhskom zapovednike [Eagleburial ground in the Voronezh reserve]. In: Proceedings of the Voronezh State Reserve. Iss. 25. Voronezh, Voronezh State Pedagogical University: 75-95.

98. Sapelnikov S.F., Sapelnikova I.I. 2020. Rezul'taty reakklimatizatsii krapchatogo suslika na pastbishche i vozmozhnye perspektivy sokhraneniya vida [Results of re-acclimatization of speckled ground squirrel in pasture and possible prospects for species conservation]. In: Prostranstvennovremennye aspekty funktsionirovaniya biosistem [Spatio-temporal aspects of the functioning of biosystems]. A collection of materials of the XVI International Scientific Ecological Conference dedicated to the memory of Alexander Vladimirovich Prisniy (Belgorod, November 24-26, 2020). Belgorod, Publishing House "BelGU" NRU "BelGU": 112-117.

99. Sapelnikov S.F., Sapelnikova I.I. 2020a. Krapchatyy suslik (Spermophilus suslicus Guld. 1770) kak ischezayushchiy vid i ego pervoe taksonomicheskoe opisanie na territorii Voronezhskoy oblasti [Spotted ground squirrel (Spermophilus suslicus Guld. 1770) as an endangered species and its first taxonomic description in the Voronezh region]. In: Proceedings of the Voronezh Reserve. Iss. 29. Voronezh, Novyy format: 298-315.

100. Sapelnikov S.F., Sokolov A.S., Lada G.A., Skryleva L.F. 2007. Pridorozhnaya koloniya krapchatogo suslika na avtotrasse Astrakhan' - Moskva v Tambovskoy oblasti [Roadside colony of speckled ground squirrel on the Astrakhan-Moscow highway in the Tambov region]. In: Teriofauna Rossii i sopredel'nykh territoriy [Theriofauna of Russia and adjacent territories] (VIII Congress of the Theriological Society). Materials of the international meeting. Moscow, KMK Scientific Press, $435 \mathrm{p}$.

101. Sapelnikov S.F., Sokolov A.S., Lada G.A., Skryleva L.F. 2007a. Ekologo-etologicheskie adaptatsii krapchatogo suslika Spermophilus suslicus $\mathrm{k}$ sovremennym usloviyam sredy obitaniya [Ecological and ethological adaptations of the speckled ground squirrel Spermophilus suslicus to modern environmental conditions]. In: Proceedings of the Voronezh State Reserve. Iss. 25. Voronezh: 279-285. 
102. Sapelnikov S.F., Sapelnikova I.I. 2019. Postnatal'noe razvitie krapchatogo suslika pri vol'ernom soderzhanii [Postnatal development of speckled ground squirrel in the enclosure]. In: Zoo culture and ecology problems. Iss. 3. Moscow, GAU "Moscow Zoo", EARAZA, SOZAR, Publishing house "ZooVetKniga": 134-151.

103. Sapelnikov S.F., Sapelnikova I.I. 2020a. Opyt reintroduktsii krapchatogo suslika (Spermophilus suslicus Güld.) v prirodnom parke "Oleniy" [Experience of reintroduction of speckled ground squirrel (Spermophilus suslicus Güld.) in the Nature Park "Oleniy"]. In: Zoo culture and ecology problems. Iss. 4. Moscow, GAU "Moscow Zoo", EARAZA: 207-216.

104. Sviridenko P.A. 1927. Rasprostranenie suslikov v Severo-Kavkazskom krae i nekotorye soobrazheniya o proiskhozhdenii fauny predkavkazskikh i kalmytskikh stepey [Distribution of ground squirrels in the North Caucasian region and some considerations about the origin of the fauna of the Ciscaucasian and Kalmyk steppes]. Izvestiya Severo-Kavkazskoy krayevoy stantsii zashchity rasteniy, 3: $123-171$.

105. Sviridenko P.A. 1940. Gryzuny [Rodents]. In: Priroda Rostovskoy oblasti [The nature of the Rostov region]. Rostov-na-Donu, Rostov Regional Book Publishing: 299-311.

106. Severtsov N.A. 1950. Periodicheskie yavleniya v zhizni zverey, ptits i gad Voronezhskoy gubernii [Periodic phenomena in the life of animals, birds and reptiles of the Voronezh province]. $2^{\text {nd }}$ ed. (printed from the 1855 edition). Moscow, Publishing House of the Academy of Sciences of the USSR, $308 \mathrm{p}$.

107. Sent-Iler K.K. 1934. Opyt izucheniya fauny Voronezhskogo gosudarstvennogo bobrovogo zapovednika [Experience in studying the fauna of the Voronezh State Beaver Reserve]. In: Voronezh State University Proceedings. V. 8. Iss. 3. Voronezh: 38-55.

108. Silantyev A.A. 1898. Zoologicheskie issledovaniya na uchastkakh ekspeditsii Lesnogo Departamenta v 1894-1896 gg. [Zoological research on the sites of the Forestry Department expedition in 1894-1896]. In: Proceedings of the expedition of the Forestry Department. Scientific department. V. IV. Iss. 2. Saint-Petersburg, Printing House E. Evdokimov, 180 p.

109. Simonovich E.I., Sidel'nikov V.V. 2014. K voprosu o sostoyanii populyatsii malogo i krapchatogo suslika na territorii Rostovskoy oblasti [On the state of the population of small and speckled ground squirrel in the Rostov region]. Mezhdunarodnyy zhurnal eksperimental'nogo obrazovaniya, 5-2: 53-54.

110. Sitnikova E.F. 2016. Krapchatyy suslik - Spermophilus suslicus Guldenstaedt, 1770 [Speckled ground squirrel - Spermophilus suslicus Guldenstaedt, 1770]. In:: Red Book of the Bryansk region. $2^{\text {nd }}$ edition. Bryansk, RIO BSU: 373.

111. Sitnikova E.F., Mishta A.V. 2006. Fauna mlekopitayushchikh Bryanskoy oblasti: vidovoy sostav, rasprostranenie i chislennost' [Fauna of mammals of the Bryansk region: species composition, distribution and abundance]. In: Izuchenie i okhrana biologicheskogo raznoobraziya Bryanskoy oblasti [Study and protection of biological diversity of the Bryansk region]. Materials for maintaining the Red Book of the Bryansk region. Iss. 2. Trubchevsk: 107-153.

112. Sklyar O.Yu., Knish M.P., Dugina O.M. 2018. Zustrichi vidiv tvarin, zanesenikh do Chervonoï knigi Ukraïni, u regioni roztashuvannya Get'mans'kogo natsional'nogo prirodnogo parku (Sums'ka oblast') [Zustrichi vidiv tvarins, entered to the Chervona Book of Ukraine, near the region of the Hetmansky National Natural Park (Sumy region)]. In: Seriya: «Conservation Biology in Ukraine». Vip. 7, T. 1. Materiali do 4-go vidannya Chervonoï knigi Ukraïni. Tvarinniy svit [Series: "Conservation Biology in Ukraine". Vip. 7, Vol. 2. Materials for the 4th edition of the Red Book of Ukraine. Fauna]. Kyiv: 258-269. (in Ukrainian)

113. Smirnov P. 2020. Marta, the last wandering pigeon. Available at: https: elementy.rukartinka_dnya1216Marta_posledniy_stranstvuyushchiy_golub $\quad 1.09 .2020$. (accessed November 13, 2020). (in Russian)

114. Smirnov P.K. 1964. K izucheniyu sutochnoy aktivnosti krapchatogo suslika [To the study of the daily activity of the speckled ground squirrel]. Vestnik Leningradskogo universiteta. Seriya biologii, 15 (3): 146-148.

115. Smykova A.V., Rodimtsev A.S. 2014. State of ground squirrel settlements (Spermophilus suslicus Guld., 1770) in Tambov region. Tambov University Reports. Series Natural and Technical Sciences, 19 (1): 217-219. (in Russian)

116. Sokolov A.S., Lada G.A. 2000. Krapchatyy suslik Citellus suslicus (Güldenstädt, 1770) [Speckled ground squirrel Citellus suslicus (Güldenstädt, 1770)]. In: Red Data Book of the Tambov Region. Animals. Tambov, IC "Tambovpoligrafizdat": 324. 
117. Sokolov A.S., Lada G.A. 2012. Krapchatyy suslik Spermophilus suslicus (Güldenstädt, 1770) [The speckled ground squirrel Spermophilus suslicus (Güldenstädt, 1770)]. In: Red Data Book of the Tambov Region. Animals. Tambov, OOO Izdatel'stvo "Yulis": 325.

118. Sokolov V.E. 1977. Sistematika mlekopitayushchikh (Otryady: zaytseobraznykh, gryzunov) [Taxonomy of mammals (Orders: lagomorphs, rodents)]. Moscow, "Vysshaya shkola", $494 \mathrm{p}$.

119. Stakheev V.V. 2014. Krapchatyy suslik - Spermophilus suslicus Guldenstaedt, 1770 [Speckled ground squirrel - Spermophilus suslicus Guldenstaedt, 1770]. In: Red Data Book of the Rostov Region. $2^{\text {nd }}$ edition. V. 1. Animals. Rostov-on-Don: 1270-1275.

120. Titov S.V. 2001. Current distribution and changes in number of the spotted souslik, Spermophilus suslicus, in the eastern part of its range. Zoologicheskiy Zhurnal, 80 (2): 234-235.

121. Titov S.V. 2005. Suslik krapchatyy Spermophilus suslicus (Güldenstädt, 1770) [Spotted ground squirrel Spermophilus suslicus (Güldenstädt, 1770)]. In: Red Data Book of the Penza Region. V. 2. Penza, OAO IPK "Penzenskaya pravda": 175 p.

122. Titov S.V., Kuzmin A.A., Naumov R.V., Ermakov O.A., Zaks S.S., Chernyshova O.V. 2015. Dinamika arealov i sovremennoe sostoyanie poseleniy nazemnykh belich'ikh v pravoberezhnykh rayonakh Povolzh'ya [The dynamics of habitats and the current state of settlements of land squirrels in the right-bank areas of the Volga region]. Penza, publ. PGU, $124 \mathrm{p}$.

123. Tokarskiy V.A. 2013. Gophers Spermophilus suslicus (Guldenst., 1769) and Spermophilus pygmaeus (Pallas, 1778) at the junction of their areas (Report 1. Past distribution). The Journal of V.N. Karazin Kharkiv National University. Series "Biology", 18 (1079): 138-143. (in Russian)

124. Tokarskiy V.A. 2013a. Krapchastiy khovrakh Spermophilus suslicus (Güldenstädt, 1770) [Spotted ground squirrel Spermophilus suslicus (Güldenstädt, 1770)]. In: Red Book of Kharkiv region. Fauna. Kharkiv, VN Karazin KhNU: 365 p. (in Ukrainian)

125. Tomanovskiy N., Popov T. 1914. (translated from German) Gyul'denshtedt o Voronezhskoy gubernii [Guldenstedt on the Voronezh province]. In: Commemorative book about the Voronezh province for 1914. Voronezh, Tipo-Litografiya Gubernskogo Pravleniya: 113-120.

126. Kheruvimov V.D. 1981. Izmeneniya $v$ faune [Changes in the fauna]. In: Atlas of the Tambov region. Moscow: $15 \mathrm{p}$.

127. Chernyaev N. 1857. Opisanie suslikov", obitayushchikh" v" yuzhnoy Rossii, i sposobov" ikh" istrebleniya [Description of gophers living in southern Russia, and methods of their extermination]. Saint-Petersburg, Tipografiya Eduarda Veymara, $68 \mathrm{p}$.

128. Chichina V.A., Pivanova S.V., Shubina Yu.E. 2009. Raspredelenie nor krapchatogo suslika $\mathrm{v}$ nekotorykh landshaftakh Lipetskogo rayona [Distribution of burrows of speckled ground squirrel in some landscapes of Lipetsk region]. In: Voprosy estestvoznaniya [Questions of natural science]. Interuniversity collection of scientific works. Iss. 16. Lipetsk, LGPU: 30-33.

129. Shakun V.V., Maksimenkov M.V. 2013. K okhrane krapchatogo suslika (Citellus suslikus) na territorii Korelichkogo rayona Grodnenskoy oblasti [To the protection of the speckled ground squirrel (Citellus suslikus) in the Korelichky district of the Grodno region]. In: Zoologicheskie chteniya [Zoological readings]. Materials of the International Scientific and Practical Conference dedicated to the memory of Professor I.K. Lopatin (Grodno, March 14-16, 2013). Grodno, Grodno State University named after J. Kupala: 325-328.

130. Shapovalov A. S. 2019. Suslik krapchatyy Spermophilus suslicus Guldenstadt, 1770 [Spotted gopher Spermophilus suslicus Guldenstadt, 1770]. In: Red Book of the Belgorod Region. Rare and endangered plants, lichens, fungi and animals. $2^{\text {nd }}$ official edition. Belgorod, Publishing House "BelGU" NRU "BelSU" 614.

131. Shapovalov A.S., Prisniy A.V. 2005. Suslik krapchatyy Spermophilus suslicus Guldenstadt, 1770 [Spotted gopher Spermophilus suslicus Guldenstadt, 1770]. In: Red Book of the Belgorod Region. Rare and endangered plants, lichens, fungi and animals. Official edition. Belgorod, OAO "Belgorodskaya oblastnaya tipografiya": $512 \mathrm{p}$.

132. Shekarova O.N., Savinetskaya L.E. 2019. Krapchatyy suslik v Moskovskoy oblasti (retrospektivnyy analiz) [Spotted ground squirrel in the Moscow region (retrospective analysis)]. In: Mlekopitayushchie Rossii: faunistika i voprosy teriogeografii [Mammals of Russia: faunistics and questions of theriogeography]. Conference materials (Rostov-on-Don, April 17-19, 2019) Moscow, KMK Scientific Press: 321-324.

133. Shilova S.A., Kalinin A.A., Shchipanov N.A., Savinetskaya L.E., Oleynichenko V.Yu. 1994. Antropogennaya transformatsiya fauny melkikh mlekopitayushchikh severa Rostovskoy oblasti [Anthropogenic transformation of the fauna of small mammals in the north of the Rostov region]. Zoologicheskiy zhurnal, 73 (3): 160-166. 
134. Shilova S.A., Neronov V.V., Shekarova O.N., Savinetskaya L.E. 2010. Dynamics of colonies of the speckled ground squirrel (Spermophilus suslicus Guld., 1770) on the northern boundary of the habitat. Izvestiya RAN. Seriya biologicheskaya, 5: 619-624. (in Russian)

135. Shokalo S.I. 2019. O sostoyanii krapchatogo suslika (Spermophilus suslicus) v Tsentral'noy Belarusi [About condition of the speckled ground squirrel (Spermophilus suslicus) in Central Belarus]. In: Zoo culture and ecology problems. Iss. 3. Moscow, GAU "Moscow Zoo", EARAZA, SOZAR, Publishing house "ZooVet Kniga": 208-215.

136. Shokalo S.I., Yankevich Yu.A. 2020. O sostoyanii krapchatogo suslika (Spermophilus suslicus) v Belarusi [About condition of the speckled ground squirrel (Spermophilus suslicus) in Belarus]. In: Ekologicheskaya kul'tura i okhrana okruzhayushchey sredy [Ecological culture and environmental protection]. III Dorofeevsky readings: materials of the international scientific and practical conference, (Vitebsk, October 28-29, 2020). Vitebsk, Voronezh State University named after P.M. Masherov: 187-190.

137. Yatsenko V.N., Sapelnikov S.F. 2007. Krapchatyy suslik Spermophilus suslicus (Guldenstaedt, 1770) [The speckled ground squirrel Spermophilus suslicus (Guldenstaedt, 1770)]. In: Pozvonochnye Tambovskoy oblasti [Vertebrates of the Tambov region]. Tambov: 224-225.

138. Yatsentkovskiy E.V. 1927. Bor'ba s suslikami v 1924 godu [Fighting gophers in 1924]. In: Susliki v Belorussii [Gophers in Belarus]. Tom II. 8. Minsk: 1-13. Polish)

139. Glowacinski Z. (ed.). 2002. Red List of Threatened Animals in Poland. Cracow, 155 p. (in

140. Gueldenstaedt I.A. 1770. Mus Suslica. Novi Commentarii Academiae Scientiarum Imperialis Petropolitanae, 14 (2): 389-402.

141. Gueldenstaedt I.A. 1770a. Spalax, novum glirium Genus. Novi Commentarii Academiae Scientiarum Imperialis Petropolitanae, 14 (2): 409-440.

142. Pallas P.S. 1770. Descriptiones quadrupedum et avium anno 1769. Observatarum. I. Mus citillus. Novi Commentarii Academiae Scientiarum Imperialis Petropolitanae, 14 (2): 548-567.

143. Sapelnikov S.F., Sapelnikova I.I. 2019. Postnatal Development of Speckled Ground Squirrel (Spermophilus suslicus Güld, 1770) (Sciuridae, Mammalia) in Captivity. Povolzhskiy Journal of Ecology, 1: 47-60.

144. Zagorodnyuk I., Glowacinski Z., Gondek A. 2008. Spermophilus suslicus. The IUCN Red List of Threatened Species 2008: e.T20492A9208074. http:dx.doi.org10.2305IUCN. UK.2008.RLTS.T20492A9208074.en.

145. Ziółek M., Kozieł M., Czubla P. 2017. Zmiany liczebności populacji susła perełkowanego Spermophilus suslicus w polsce wschodniej. Polish Journal of Natural Sciences, 32 (1): 91-104. (in Polish)

\section{ИНФОРМАЦИЯ ОБ АВТОРАХ}

Сапельников Сергей Фёдорович, зоолог Ломовского природного ландшафтного парка, Воронежская область, Россия

Сапельникова Инна Игоревна, старший научный сотрудник Воронежского государственного природного биосферного заповедника имени В.М. Пескова, г. Воронеж, Россия

\section{INFORMATION ABOUT THE AUTHORS}

Sapelnikov Sergey F., Zoologist of Lomovskoy Natural Landscape Park, Voronezh Region, Russia

Sapelnikova Inna I., Senior Researcher of Voronezh State Natural Biosphere Reserve named after V.M. Peskova, Voronezh, Russia 